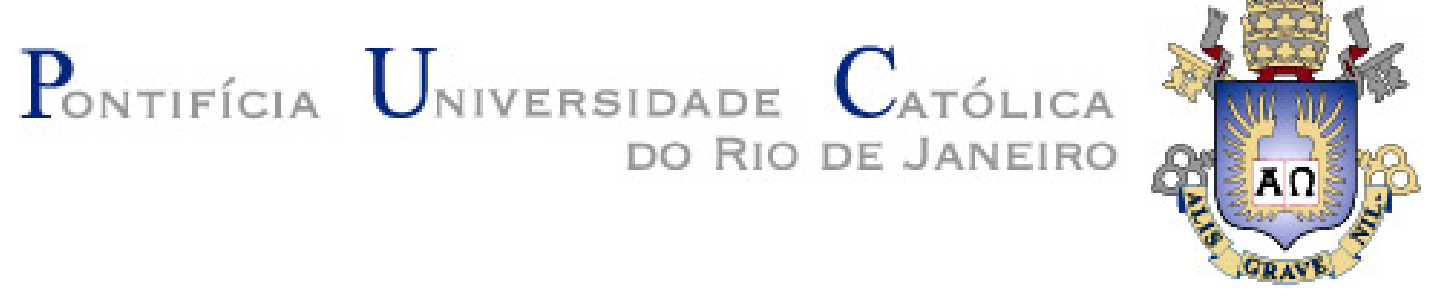

Carlos Augusto Ruppenthal Milani

\title{
IDENTIFICAÇÃO E SOLUÇÃO DE TRINCAS DE LAMINAÇÃO A QUENTE EM AÇOS ESTRUTURAIS PROCESSADOS EM LINGOTAMENTO CONTÍNUO
}

\section{Dissertação de Mestrado}

Dissertação apresentada como requisito parcial para obtenção do grau de Mestre pelo Programa de Pós-Graduação em Engenharia de Materiais e de Processos Químicos e Metalúrgicos da PUC-Rio.

Orientador: Prof. Marcos Venicius Soares Pereira 
GRAvB

\section{IDENTIFICAÇÃO E SOLUÇÃO DE TRINCAS DE LAMINAÇÃO A QUENTE EM AÇOS ESTRUTURAIS PROCESSADOS EM LINGOTAMENTO CONTÍNUO}

Dissertação apresentada como requisito parcial para obtenção do grau de Mestre pelo Programa de Pós-Graduação em Engenharia de Materiais e de Processos Químicos e Metalúrgicos da PUC-Rio. Aprovada pela Comissão Examinadora abaixo assinada:

Prof. Marcos Venicius Soares Pereira

Orientador

Departamento de Engenharia Química e de Materiais

PUC - Rio

Prof. José Carlos D'Abreu

Departamento de Engenharia Química e de Materiais

PUC - Rio

Prof. Fathi Arlf Ibrahim Darwish

Departamento de Engenharia Civil

UFF

Prof. Márcio da Silveira Carvalho Coordenador Setorial do Centro Técnico Científico da PUC- Rio 
Todos os direitos reservados. É proibida a reprodução total ou parcial do trabalho sem autorização da universidade, do autor e do orientador.

\section{Carlos Augusto Ruppenthal Milani}

Graduou-se em Engenharia Metalúrgica com complementação em Engenharia Industrial pela PUC-Rio em 1973, com especialização em Steelmaking Engineering em Nagoya, Japão, em 1985. Acumula mais de 40 anos de experiência profissional relacionada com os setores de metalurgia do ferro e suas ligas em empresas no Brasil e no exterior, incluindo a publicação de artigos técnicos, palestras, conferências e ministração de cursos de treinamento a aperfeiçoamento.

Ficha Catalográfica

Milani, Carlos Augusto Ruppenthal

Identificação e solução de trincas de laminação a quente em aços estruturais processados em lingotamento contínuo / Carlos Augusto Ruppenthal Milani; orientador: Marcos Venicius Soares Pereira. - 2016.

70 f.: il. color.; $30 \mathrm{~cm}$

Dissertação (mestrado)-Pontifícia Universidade Católica do Rio de Janeiro, Departamento de Engenharia Química e de Materiais, 2016.

Inclui bibliografia

1. Engenharia de Materiais - Teses. 2. Engenharia Química Teses. 3. Transformações peritéticas. 4. Defeitos em laminação a quente. 5. Proposta de solução do trincamento. 6. Aço de substituição. I. Pereira, Marcos Venicius Soares. II. Pontifícia Universidade Católica do Rio de Janeiro. Departamento de Engenharia Química e de Materiais. III. Título. 


\section{Agradecimentos}

À PUC-Rio, especialmente ao Departamento de Engenharia Química e de Materiais, pela oportunidade ímpar que me foi concedida de retornar a esta instituição de ensino e poder revivenciar a experiência de participar em seu corpo discente. Meus pessoais agradecimentos ao membros do corpo docente e colaboradores que me tornaram meritório de suas atenções e dedicação extremas.

Também gostaria de expressar sinceros agradecimentos a alguém que não conheci pessoalmente, o eminente metalurgista Edgar Collins Bain (1891 -1971). Sua imortal obra Functions of the Alloying Elements in Steel, publicada pela ASM International em 1939, até os dias de hoje é uma referência para os estudiosos da metalurgia do aço. A microestrutura resultante da decomposição eutetóide da austenita em ferrita mais carbonetos é denominada bainita em homenagem ao seu descobridor Edgard Bain. A formação da fase metaestável martensita é explicada por um fenômeno desde então denominado Bain Strain.

A leitura dessa sua obra foi para mim determinante pelo apreço por tudo relacionado com a metalurgia do ferro e do aço. Permito-me destacar algo decisivo dito por ele nesse contexto em sua Introdução ao tema: "It is now established that an element does not, merely by its auspicious presence alone, contribute to a property, as sugar lends to sweetness, without regard for the structure favored by the element under specific circumstances".

E, por último, gostaria de agradecer à CIAFAL - Comércio e Indústria de Artefatos de Ferro e Aço pelo apoio e cessão das amostras de material laminado que compõem esta dissertação. 


\section{Resumo}

Milani, Carlos Augusto Ruppenthal; Pereira, Marcos Venicius Soares. Identificação e Solução de Trincas de Laminação a Quente em Aços Estruturais Processados em Lingotamento Contínuo. Rio de Janeiro. 2016. 70p. Dissertação de Mestrado - Departamento de Engenharia Química e de Materiais. Pontifícia Universidade Católica do Rio de Janeiro.

O advento e consolidação do processo de lingotamento contínuo, hoje dominante no setor siderúrgico, trouxe à tona os crescentes esforços de investigação e análise dos fenômenos relacionados com o comportamento dos aços a elevadas temperaturas. Diferentemente do lingotamento convencional, o lingotamento contínuo é um processo dinâmico no qual ocorre a oscilação do molde enquanto o veio em solidificação é continuamente extraído ao mesmo tempo que é submetido a um segundo resfriamento dito secundário. No Brasil há um parque industrial de empresas que se dedicam à laminação a quente de semiacabados fornecidos por terceiros como placas de aço, as quais são cortadas a quente sob a forma de tarugos de seção quadrada que são então destinados a laminação. A linha de produção dessas empresas compreende basicamente produtos estruturais tais como barras chatas, barras redondas, barras quadradas, cantoneiras e até perfis especiais destinados à indústria automobilística e de máquinas. Uma série catastrófica de eventos de qualidade relacionados com trincas emergiu da laminação de tarugos de aço SAE 1020 oriundos de placas continuamente lingotadas. Essas trincas, porventura preexistentes ou latentes no interior das placas podem ter sido exacerbadas por efeitos de zonas termicamente afetas durante as operações de corte. A solução proposta para superação dessa contingência foi então a de criação de um aço de substituição com teores inferiores de carbono e maior conteúdo de ligas que preservasse as propriedades mecânicas do material laminado. Teores inferiores de carbono não apenas contribuem para a minimização dos efeitos oriundos das transformações peritéticas como também agem favoravelmente sobre as consequências decorrentes de zonas termicamente afetadas. Essa proposta foi bem sucedida e a composição química desse aço de substituição denominado pseudo-1020 passou a ser desde então padrão de laminação. Amostras do SAE 1020 laminado com ocorrências de trincas e do aço de substituição foram obtidas e transformadas em 
corpos de prova para a realização de ensaios de tração, dureza e impacto. Essa dissertação objetiva apresentar toda a fenomenologia relacionada com a ocorrência de trincas superfícies e internas em aços continuamente lingotados, em especial os submetidos a transformações peritéticas, e as premissas que fundamentaram a criação do aço de substituição e os resultados auferidos.

\section{Palavras-chave}

Transformações peritéticas; defeitos em laminação a quente; proposta de solução do trincamento; aço de substituição 


\section{Abstract}

Milani, Carlos Augusto Ruppenthal; Marcos Venicius Soares (Advisor). Identification and Solution of Hot Rolling Cracking in Structural Steels Processed by Continuous Casting. Rio de Janeiro, 2016. 70p. MSc. Dissertation - Departamento de Engenharia Química e de Materiais. Pontifícia Universidade Católica do Rio de Janeiro.

The advent and consolidation of the continuous casting process, currently dominant in the Steel Industry, raised the increasing investigation and analyses efforts on the phenomena related to the high-temperature behavior of the steels. Unlike the conventional ingot casting process, the continuous casting is a dynamic process in which occurs the mold oscillation while the strand under solidification is continuously withdrawn and submitted to a secondary cooling operation. In Brazil, it can be found an industrial park of companies dedicated to the hot rolling of semis supplied by third parties as steel slabs, which ones are flame cut in the form of square billets for rolling. The production mix of these companies encompasses structural steels such as flat bars, round bars, angles and even special profiles for the machines and automotive industries. A catastrophic series of quality events related to cracking emerged from the rolling of SAE 1020 billets made from continuously cast slabs. These cracks, perhaps pre-existing or latent in the inner parts of the slabs could be exacerbated by thermal affected zones during the flame-cut operations. The propose solution to overcoming this contingency was the creation of a replacement steel grade with lower carbon content and higher alloy content aiming to preserve the mechanical properties of the as rolled material. Lower carbon contents does not only contributes to the minimization of the effects arising from the peritetic transformations as also act in favor on the consequences coming from thermal affected zones. This proposition was well successful and the chemical composition of this replacement steel called pseudo1020 since then became a rolling standard. Samples of the rolled SAE 1020 steel with cracks occurrences and of the replacement steel were taken and transformed in specimens for tensile strengths, hardness and impact tests.This paper aims to present all related phenomena to the occurrence of inner and superficial cracks in continuously cast steels, in special the ones submitted to peritetic transformations, and the premises that support the creation of a replacement steel and the related results. 


\section{Keywords}

Peritetic transformation; hot rolling defects; proposition for cracking solution; replacement steel 


\section{Sumário}

1. Introdução

2. Apresentação do problema 17

2.1 Fenomenologia associada ao lingotamento de aços peritéticos $\quad 17$

2.1.1 Fundamentos

2.1.2 Lingotamento contínuo

2.2 Da sucessão de defeitos encontrados em laminados a quente

2.2.1 Parque industrial de empresas laminadoras

2.2.2 Processamento das placas

2.2.3 Defeitos de laminação

3. Solução do problema 46

3.1 Análise, avaliação e influência de zonas termicamente afetadas 46

3.2 Proposição de outra composição química 50

4. Procedimento experimental 53

5. Resultados e discussão 56

6. Conclusão e proposição para futuros trabalhos 64

7. Referências bibliográficas 66 


\section{Lista de Figuras}

Figura 1 - Fenômenos relacionados com o lingotamento contínuo 13

Figura 2 - Defeitos superficiais e internos 14

$\begin{array}{ll}\text { Figura } 3 \text { - Marcas de oscilação } & 15\end{array}$

Figura 4 - Rompimento da casca de solidificação em um veio em lingotamento

Figura 5 - Diagrama Fe-C (A) e detalhamento da região de 17 interface (B)

Figura 6 - Interpretação esquemática das reações peritéticas

Figura 7 - Diagrama binário peritético

Figura 8 - Transformação peritética na cristalização da austenita 19

Figura 9 -Três estágios da reação peritética

Figura 10 - Severidade de segregação e reação peritética

Figura 11 - Representação das zonas de reduzida ductilidade

Figura 12 - Apresentação esquemática da interface sólido/líquido durante o lingotamento

Figura 13 - Aparência típica de trinca de resfriamento em um lingote de 25 atribuída ao fenômeno de reduzida ductilidade dos aços a elevadas temperaturas

Figura 14 - Grandes grãos de austenita formada anteriormente

Figura 15 - Típico mecanismo de formação de trincas superficiais

Figura 16 - Trinca transversal na base de uma marca de oscilação em uma placa de aço $0,2 \% \mathrm{C}$

Figura 17 - Mecanismo de formação de segregação no menisco do aço líquido27

Figura 18 - Diagrama binário Fe-S

Figura 19 - Pó fluxante e fenômeno de colagem 
Figura 20 - Operação de escarfagem manual e placas 30 escarfadas

Figura 21 - Representação esquemática de máquina de lingotamento

Figura 22 - Exemplo de inchamento lateral

Figura 23 - Temperatura superficial em função da distância

Figura 24 - Trincas internas em placa de aço

Figura 25 - Exemplos de trincas em placa de aço SAE 1020 destinadas a laminação a quente

Figura 26 - Exemplo de perfis especiais fabricados por empresa laminadora

Figura 27 - Tarugos continuamente lingotados em aço SAE $1020 \quad 36$

Figura 28 - Laminação de produtos longos e desbastador 36

Figura 29 - Passes de laminação de barras 37

Figura 30 - Placas de aço e máquina de corte 37

Figura 31- Dessulfurização de ferrro-gusa líquido 38

Figura 32 - Convertedores a oxigênio 38

Figura 33 - Panela de vazamento de aço líquido 39

Figura 34 - Desgaseificador a vácuo 39

Figura 35 - Forno de reaquecimento RHF 39

Figura 36 - Máquina de lingotamento contínuo 40

Figura 37- Perfurações de veio induzidas por hidrogênio dissolvido

Figura 38 - Macrografia $\quad 43$

Figura 39 - Estruturas internas de tarugos x placas de aço 43

Figura 40 - Série de eventos de defeitos em laminados a quente $\quad 45$

Figura 41-Resultados de empresa laminadora 48

Figura 42 - Zonas termicamente afetadas 48 
Figura 43 - Trinca superficial em placa de aço 1045

Figura 44 - Influência do teor de carbono na dureza da martensita

Figura 45 - Amostra de aço SAE 1020 exibindo trincas de laminação

Figura 46 - Amostra do aço de substituição

Figura 47 - Corpos de prova

Figura 48 - Série de macrografias

Figura 49 - Microestrutura de aço SAE 1020

Figura 50 - Energia de impacto versus temperatura

Figura 51 - Efeito do teor de manganês na transição dúctil/frágil em aços $0,05 \%$ C 


\section{Introdução}

Diferentemente do lingotamento convencional em que um metal no estado líquido é vazado em uma lingoteira estacionária que exerce o papel de um molde, o processo de lingotamento contínuo caracteriza-se por altas velocidades de solidificação, elevados gradientes de temperatura e intenso fluxo de metal líquido em seus primeiros momentos de solidificação.

O começo do crescimento da camada ou casca de solidificação na área do menisco é determinada por vários fatores como o fluxo local de calor, sua resistência e a dinâmica do fluido (1). Nessa região, surgem defeitos superficiais como marcas de oscilação, as quais influenciam o processo de crescimento da camada (casca) em solidificação no molde.

Enquanto o metal se solidifica, o veio em lingotamento é continuamente extraído, caracterizando assim o processo contínuo de lingotamento. O material como lingotado sob a forma de um semiacabado com estrutura bruta de fusão é cortado nos comprimentos pré-estabelecidos e destinado às operações subsequentes de laminação a quente. Os produtos de lingotamento contínuo abrangem secções quadradas (tarugos e blocos), retangulares (placas), redondos e perfis:

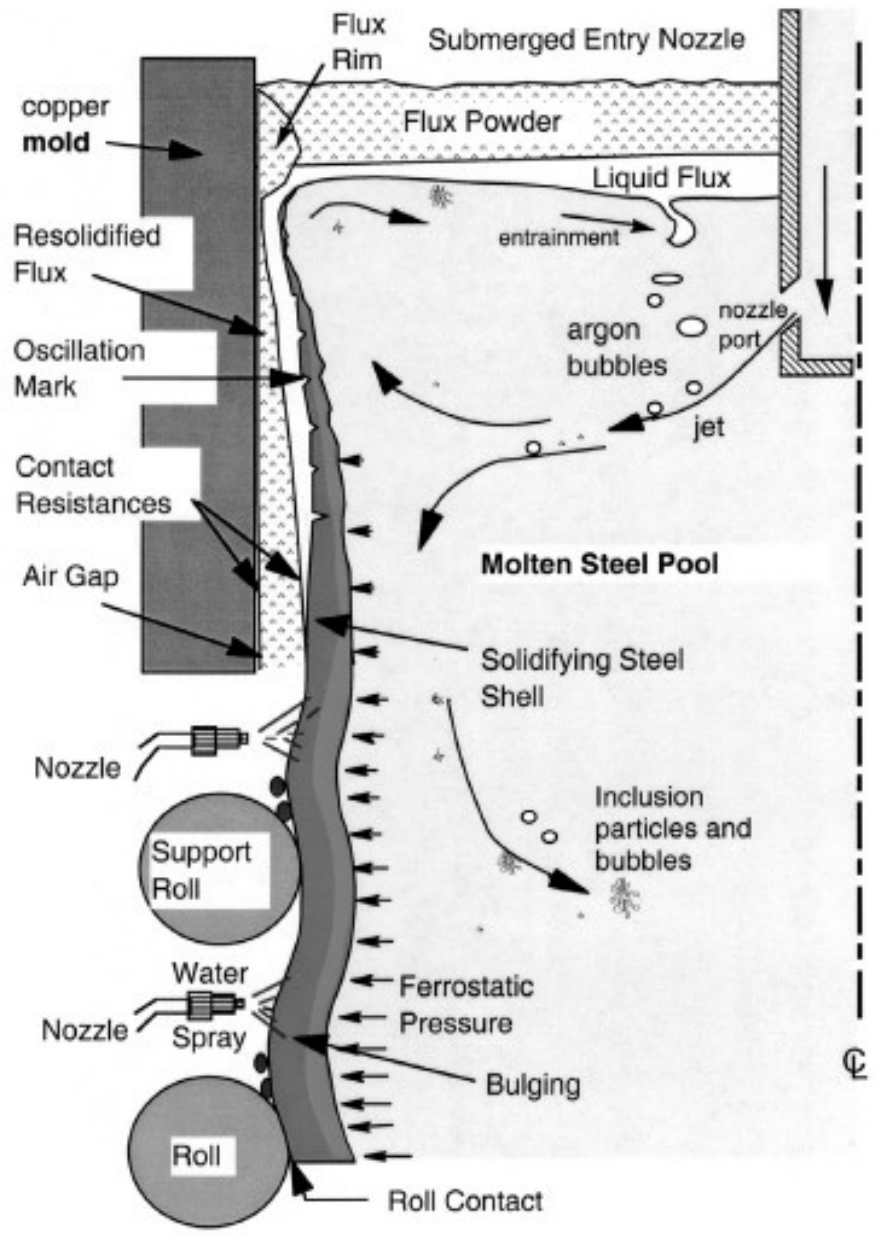

Figura 1 - Fenômenos relacionados com o lingotamento contínuo de placas de aço (2) 
Esse conjunto de fenômenos que atuam nos estágios iniciais de solidificação, as transformações de fase (austenita/ferrita) e microestruturas resultantes que operam nessa parte do processo controlam microsegregações e mecanismos de formação de defeitos superficiais e internos que eventualmente podem emergir no material continuamente lingotado, como mostrado na Figura 2.
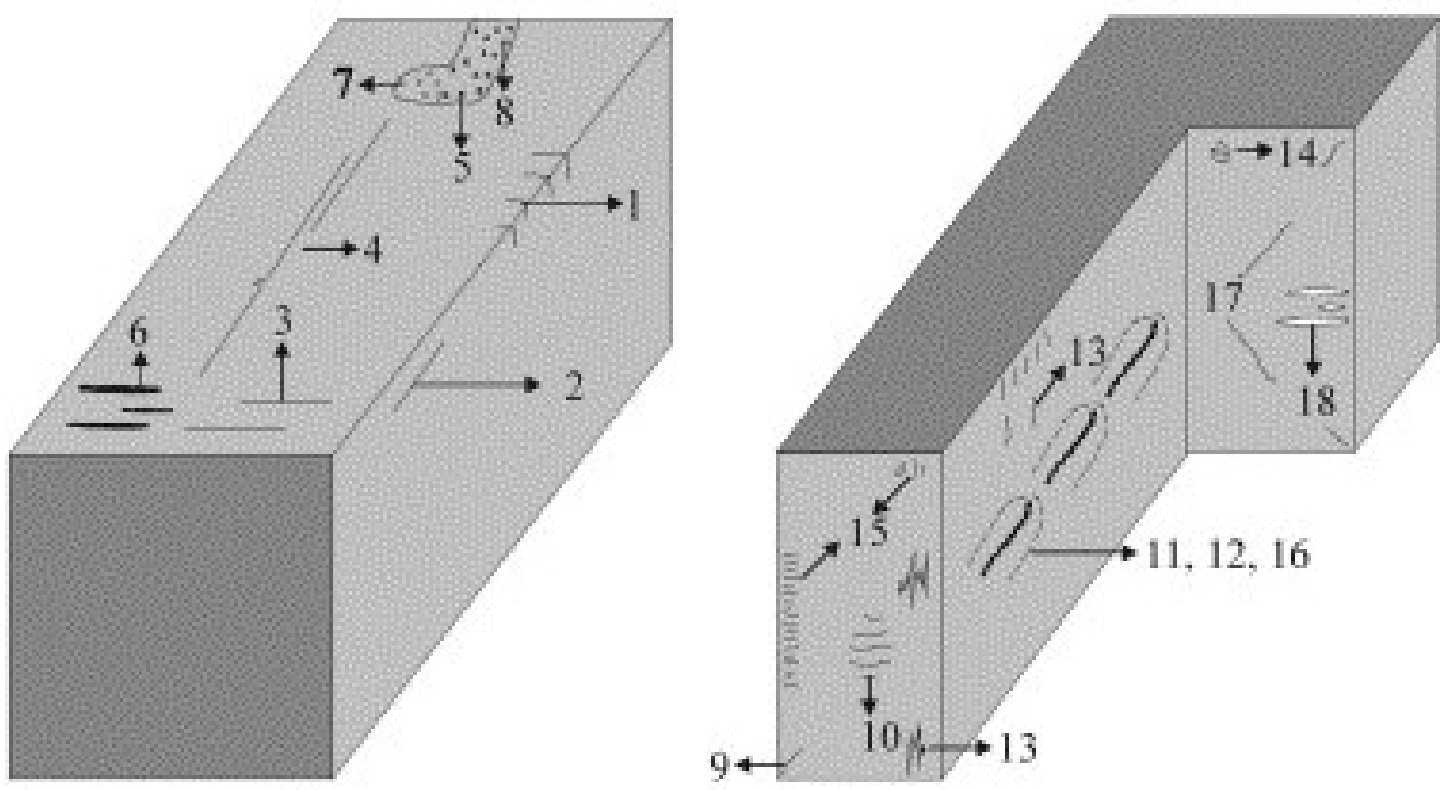

1. Trincas transversais de quina

2. Trincas longitudinais de quina

3. Trincas transversais

4. Trincas longitudinais faciais

5. Trincas em estrela

6. Marcas profundas de oscilação

7. Orifícios

8. Macroinclusões

9. Trincas

10. Trincas laterais médias

11. Segregação central

12. Porosidade

13. Trincas médias

14. Inclusões não metálicas

15. Riscas subsuperficiais

16. Cavidade de contração

17. Trincas diagonais

18. Porosidade

Figura 2 - Defeitos superficiais (à esquerda) e internos (à direita) (3) 
Além desses fenômenos, concorrem igualmente entre os fatores de formação de defeitos no material continuamente lingotado aspectos de ordem mecânica, de refrigeração primária e secundária e variáveis de processo como amplitudes e frequências de oscilação do molde, grau de conicidade de suas paredes, velocidades de lingotamento, oscilações nos níveis de aço líquido no molde, graus de sobreaquecimento do metal líquido, tipos de aços (composições químicas) e as próprias condições de alinhamento das máquinas de lingotamento contínuo $(4,5,6)$.

O "efeito quina" é outro fator a ser considerado. As quinas perdem calor mais rapidamente que o restante do produto lingotado, criando deste modo um foco de tensões residuais intrínsecas. Uma correta geometria do molde, no que diz respeito ao dimensionamento e seleção dos raios de quina, é fator determinante na superação de problemas relacionados com essa contingência.

Cabe entre esses destacar o efeito da pressão ferrrostática, responsável pelo fenômeno de inchamento (bulging) $(7,8)$ das placas de aço continuamente lingotadas, mais severo nas faces estreitas que são mais vulneráveis a este efeito. As máquinas de lingotamento contínuo de placas atingem elevadas alturas de elevação, tanto maiores quanto maiores as espessuras do material lingotado.

Outro fenômeno que cabe destacar é o de formação de marcas de oscilação oriundas no molde, Figura 3 , as quais contribuem sobremaneira para a deterioração da qualidade superficial do material continuamente lingotado. Essas marcas podem ser relacionadas diretamente a defeitos subsuperficiais $(9,10)$, em especial a formação de trincas transversais (11). Trincas transversais a quente podem provocar o catastrófico fenômeno de rompimento da casca em solidificação (breakout), como ilustrado na Figura 4.

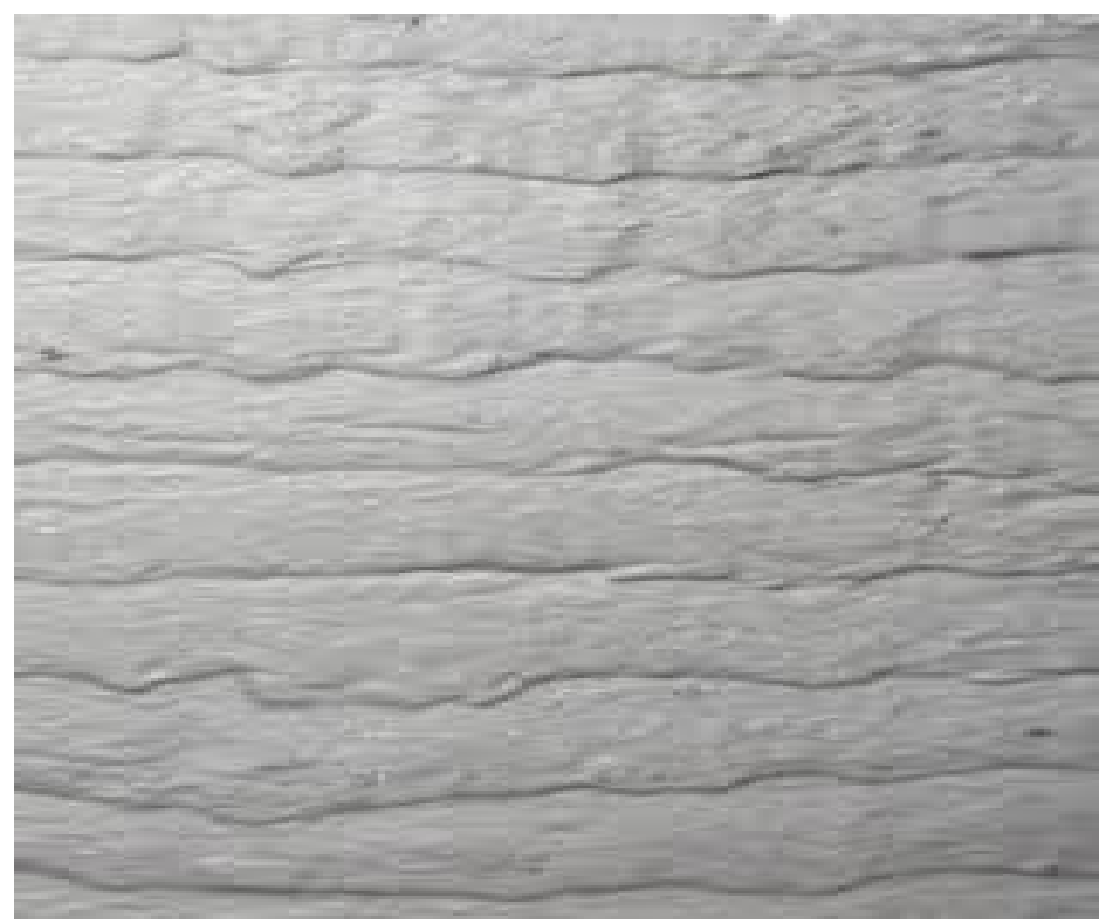

Figura 3 - Marcas de oscilação (11) 


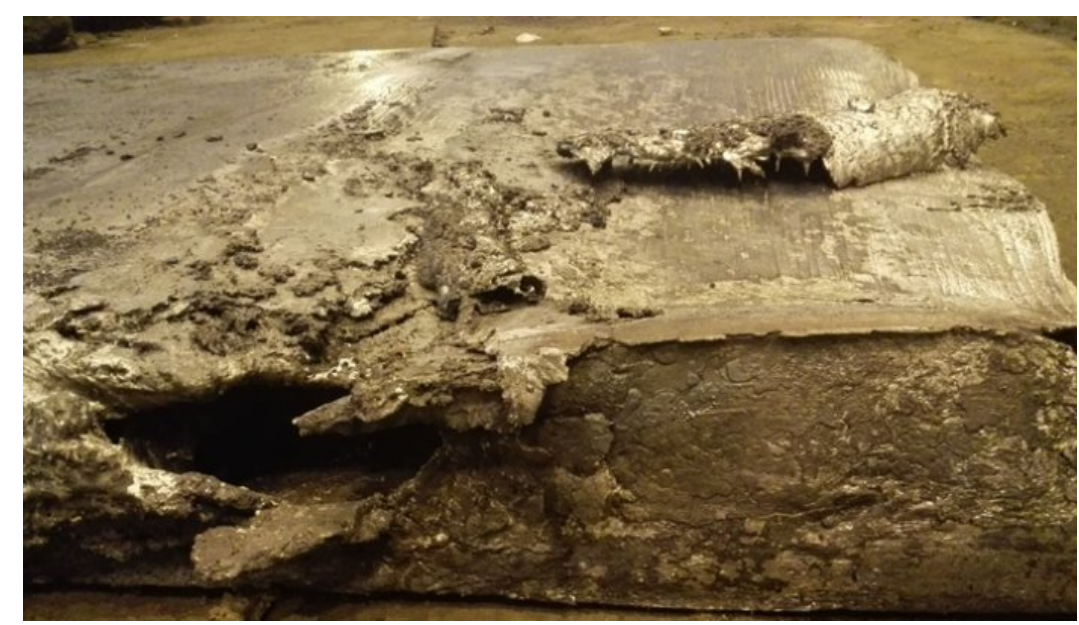

Figura 4 - Rompimento da casca de solidificação em um veio em lingotamento (12)

A influência da composição química e o papel das interfaces nas frentes de solidificação sobre a ocorrência de defeitos no produto continuamente lingotado, como trincas a elevadas temperaturas, fizeram emergir o conceito de crack sensitive steels. Esse conceito de maior ou menor suscetibilidade apresentada pelos aços à ocorrência de trincas durante o processamento dos mesmos em lingotamento contínuo é assunto amplamente explorado, como, por exemplo, nas referências $(13,14)$.

Placas de aço continuamente lingotadas são fundamentalmente destinadas à produção de laminados planos. Mas existe aqui no Brasil um grande parque de produtores independentes conhecidos como relaminadores não integrados que não dispõem de instalações de aciaria e que adquirem placas no mercado e a partir dessas produzem blocos e tarugos que são laminados a quente em produtos longos com finalidades estruturais. Essas placas são tradicional e usualmente encomendadas segundo a composição química ABNT/SAE/AISI 1020 a qual corresponde a aços carbono de média resistência (ASTM A36 para produtos perfilados com carbono máximo $0,26 \%$ em peso com limite de escoamento mínimo de 195 a $259 \mathrm{MPa}$. As faixas de composições químicas usuais para esse tipo de aço situam-no no patamar das reações peritéticas no equilíbrio das ligas $\mathrm{Fe}-\mathrm{C}$.

Uma série de eventos de qualidade e perdas de produção de produtos laminados a quente conformados a partir de placas encomendadas e produzidas estritamente em observância a essa composição química motivou uma investigação e análises detalhadas desses acontecimentos e a busca de uma solução de superação desses problemas.

A dissertação em pauta discute esse trabalho investigatório sobre as causas dessas falhas de qualidade, as consequências advindas e apresenta a proposta de solução encontrada de substituição do material SAE 1020 clássico por um substituto que respeitasse suas propriedades mecânicas de aplicação de acordo com a normalização técnica aplicável. O propósito da formulação desse aço de substituição foi o de privilegiar menores teores de carbono seguindo os fundamentos que norteiam a manufatura dos aços microligados de alta resistência e baixa liga (HSLA - High Strength Low Alloy). 


\section{Apresentação do problema}

\subsection{Fenomenologia associada ao lingotamento de aços peritéticos}

\subsubsection{Fundamentos}

As ligas $\mathrm{Fe}-\mathrm{C}$, popularmente denominadas aços, construíram sua história de sucesso como material industrial dominante graças aos fatores concorrentes da alotropia do elemento metálico ferro e a presença do carbono em sua metalurgia. No diagrama de equilíbrio das ligas Fe-C observa-se a ocorrência de reações peritéticas, destacada na Figura 5 (ponto tríplice).

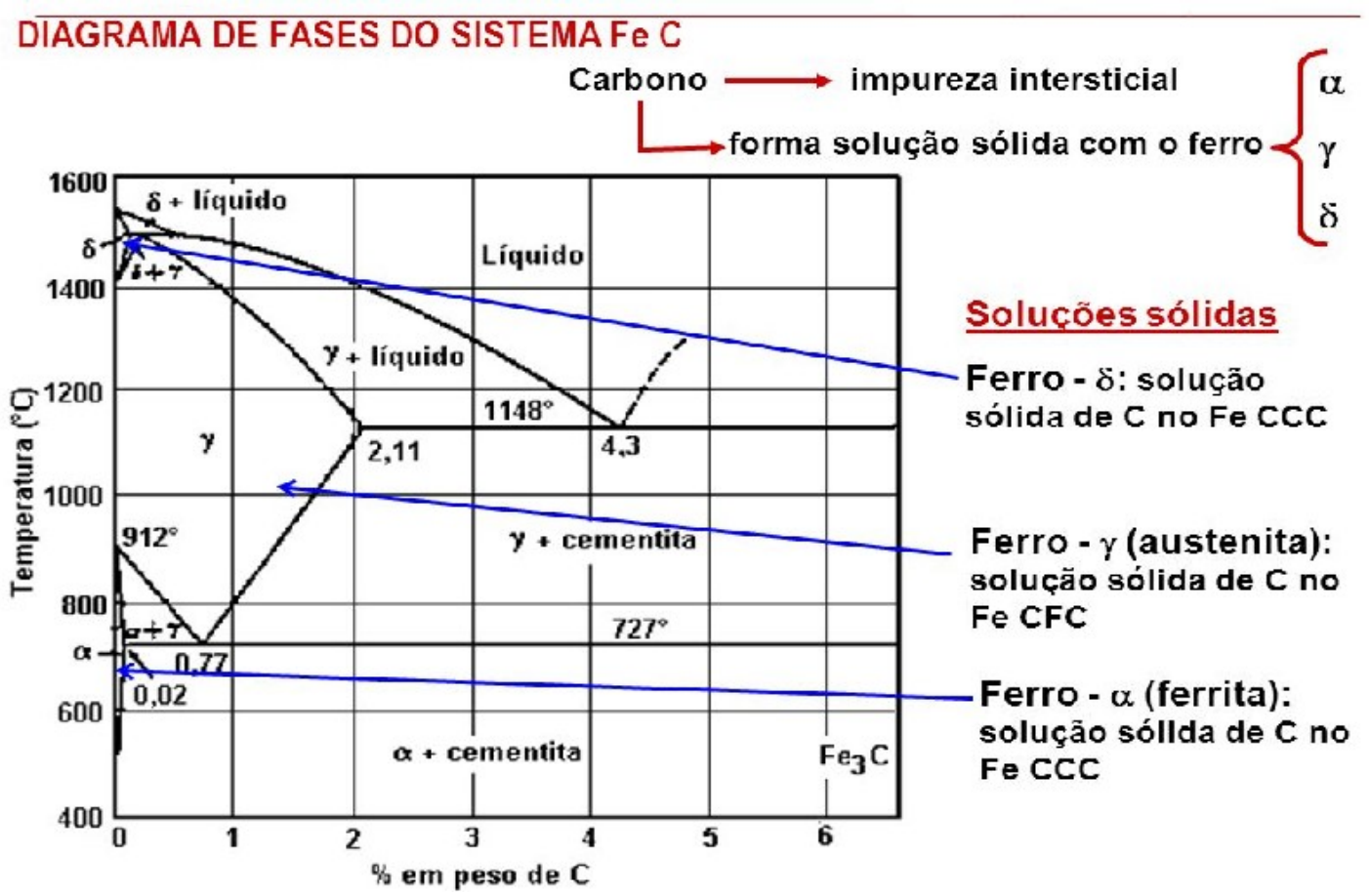

(A)

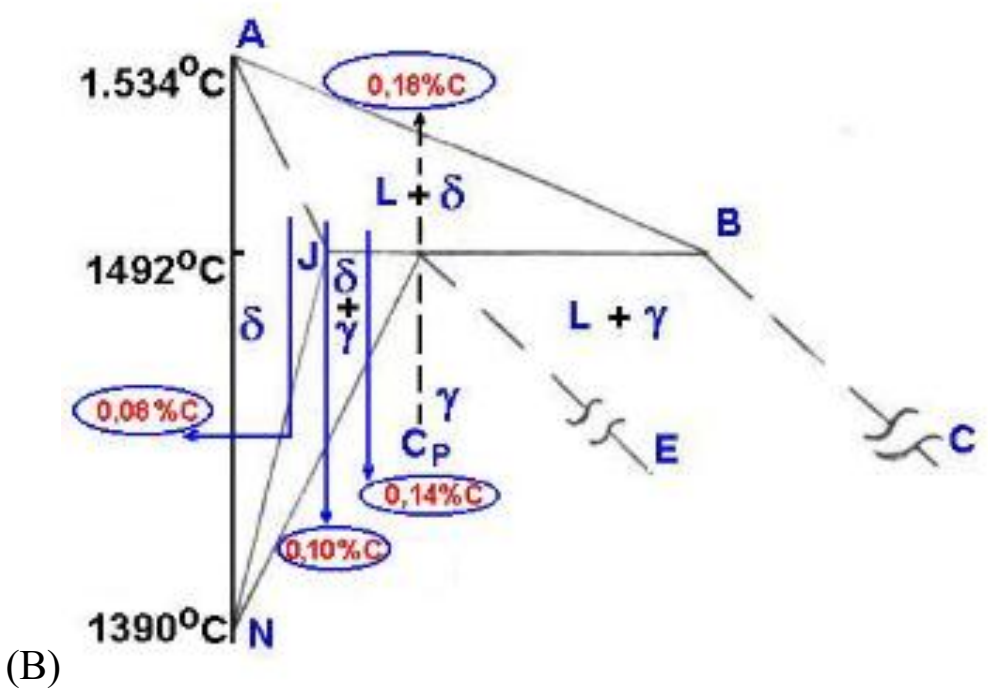

Figura 5 - Diagrama de equilíbrio Fe-C (A) e detalhamento da região de interface (B) 
O termo peritético designa as reações nas quais duas ou mais fases (gás, líquido, sólido) reagem a uma temperatura definida para formar uma nova fases que é estável abaixo desta temperatura.

Usualmente, peritético refere-se a reações nas quais uma fase líquida reage com ao menos uma fase sólida para formar uma nova fase sólida no resfriamento pela isotérmica peritética.

A equação generalizada dessa reação é: Líquido $+\boldsymbol{\alpha} \rightarrow \boldsymbol{\beta}$.

As estruturas peritéticas formam-se por meio de mecanismos que se iniciam quando todas as fases encontram-se em contato uma com as outras.

A transformação peritética ocorre quando a fase líquida e a fase sólida $\boldsymbol{\alpha}$ estão isoladas pela fase $\boldsymbol{\beta}$, como mostrado na Figura 6 . À medida que a fase $\boldsymbol{\beta}$ envolve as partículas sólidas $\boldsymbol{\alpha}$, os átomos de $\boldsymbol{\alpha}$ devem se difundir através da crosta de $\boldsymbol{\beta}$ de modo a alcançarem o líquido e a reação prossiga.

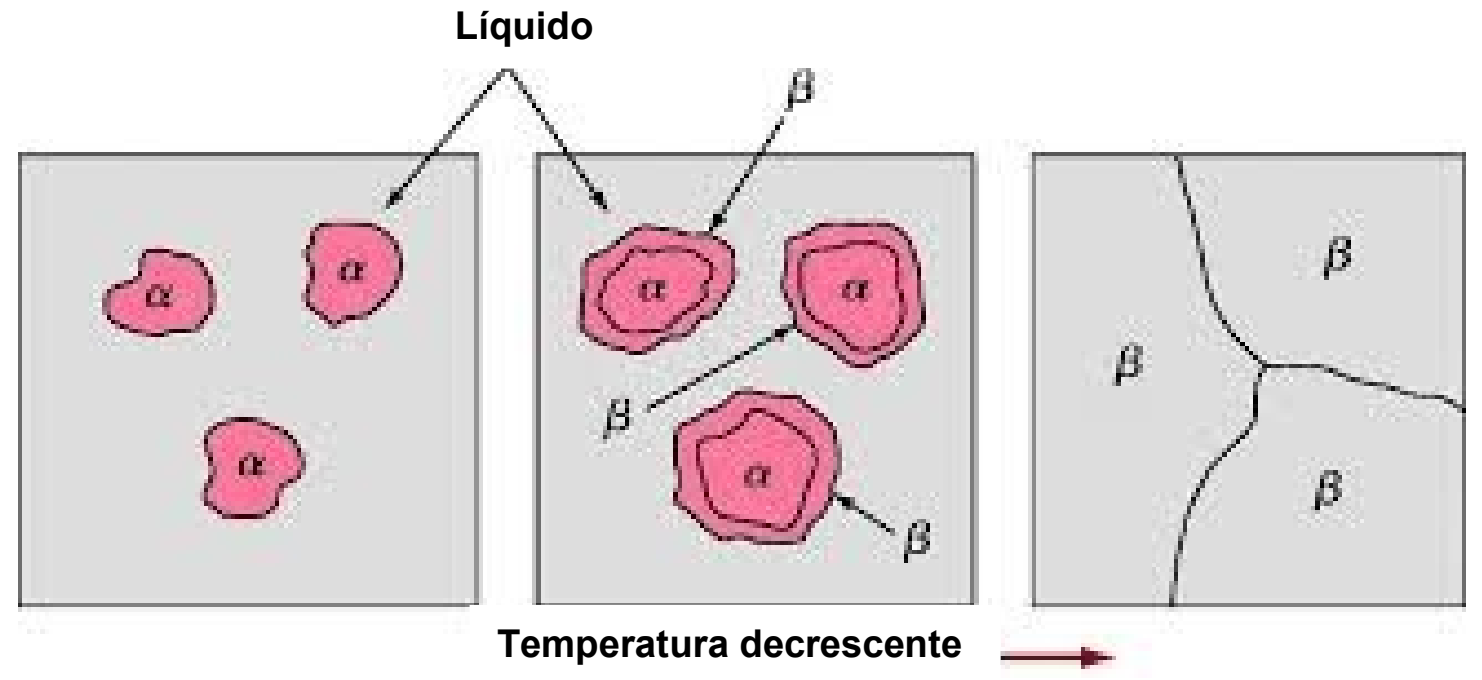

Figura 6 - Interpretação esquemática das reações peritéticas (15)

Um típico diagrama binário peritético é em prosseguimento mostrado, contendo três regiões de duas fases. A regra da alavanca é aplicável em cada uma dessas regiões.

Um material de composição inicial $\mathbf{C}_{\mathbf{o}}$ em fase líquida no ponto $\mathbf{A}$ da Figura 7 se transforma em $\boldsymbol{\alpha}+\mathbf{L}$ durante o resfriamento. Mas à temperatura peritética $\mathbf{T}_{\mathbf{p}}, \boldsymbol{\alpha}$ de composição $\mathbf{C}_{\boldsymbol{\alpha}} \mathbf{p}$ e líquido de composição $\mathbf{C}_{\mathbf{l}} \mathbf{p}$ reagem para formar $\boldsymbol{\beta}$ de composição $\mathbf{C}_{\boldsymbol{\beta}} \mathbf{p}$. Na composição peritética $\mathbf{C}_{\boldsymbol{\beta}} \mathbf{p}$, toda a fase $\boldsymbol{\alpha}$ e todo o líquido presentes logo acima de $\mathbf{T}_{\mathbf{p}}$ são consumidos para produzir um fase única $\boldsymbol{\beta}$.

Após a reaçao peritética, a composição da fase $\boldsymbol{\beta}$ produzida segue a linha solvus e um precipitado $\boldsymbol{\alpha}$ se forma dentro de $\boldsymbol{\beta}$. 


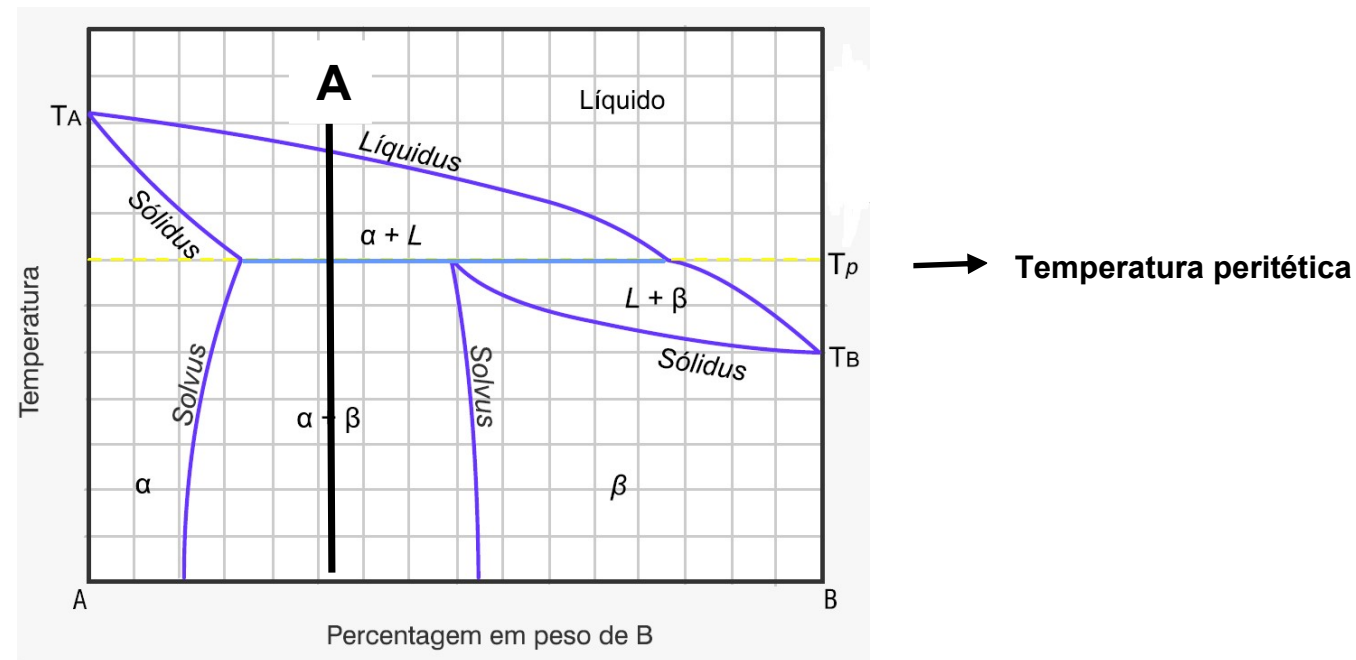

Figura 7 - Diagrama binário peritético (16)

No caso particular das ligas dos aços, a reação peritética é expressa por: Fase

Líquida + ferrita delta $(\delta) \rightarrow$ austenita $\gamma$ (o líquido L reage com a ferrita $\delta$ para formar austenita $\gamma$ na interface $\mathrm{L} / \delta$ ).

Os primeiros cristais de austenita $\gamma$ aparecem na fronteira de interface ferrita $\delta /$ fase líquida e rapidamente crescem ao longo desta fronteira formando um invólucro até que este cubra completamente a superfície de $\delta$ e o separe do líquido. A transformação peritética começa nesse ponto por difusão atômica do líquido para a ferrita $\delta$ até sua completa extinção.
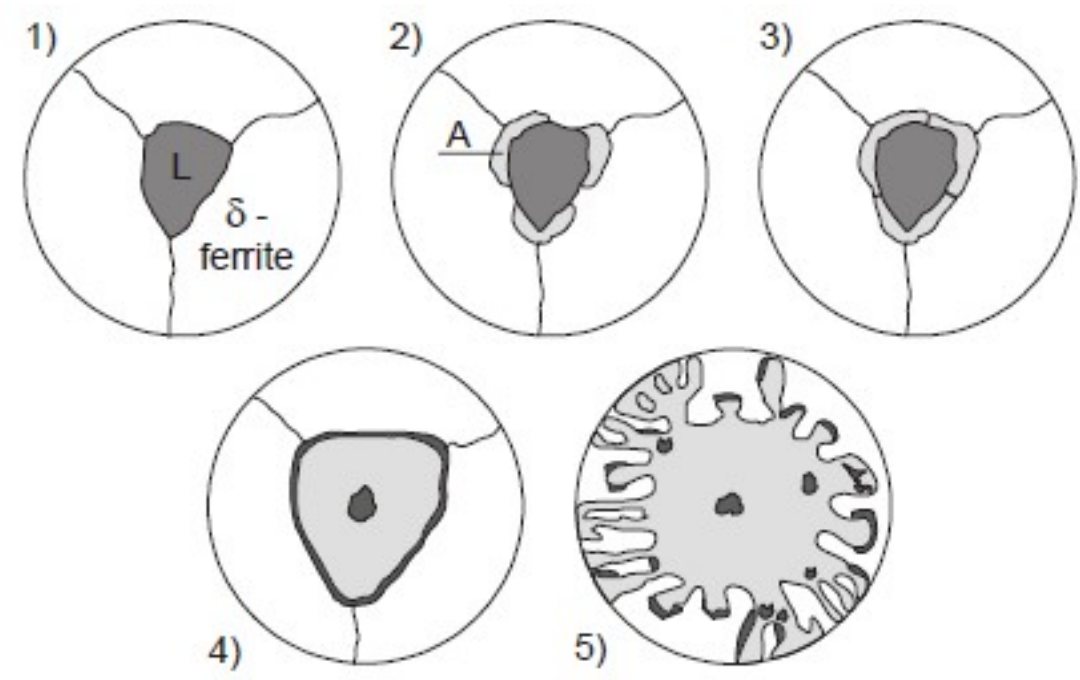

Figura 8 - Transformação peritética na cristalização da austenita (17)

A figura 9 oferece uma ilustração desses complexos mecanismos de formação de uma reação peritética em ligas de aço. 


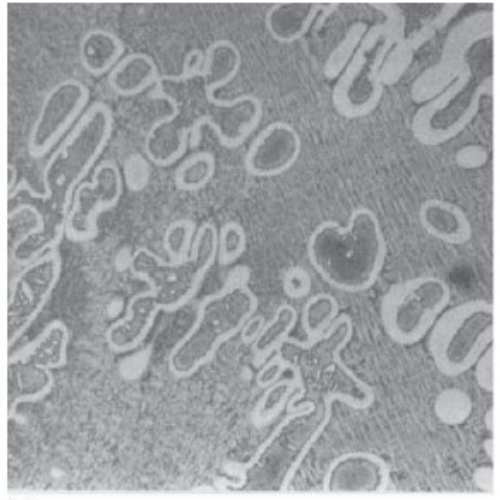

(a)

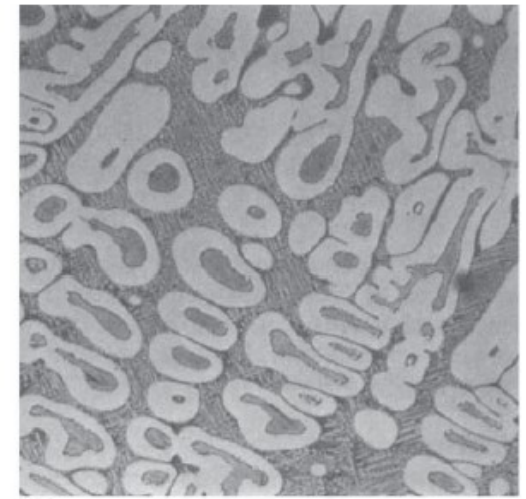

(b)

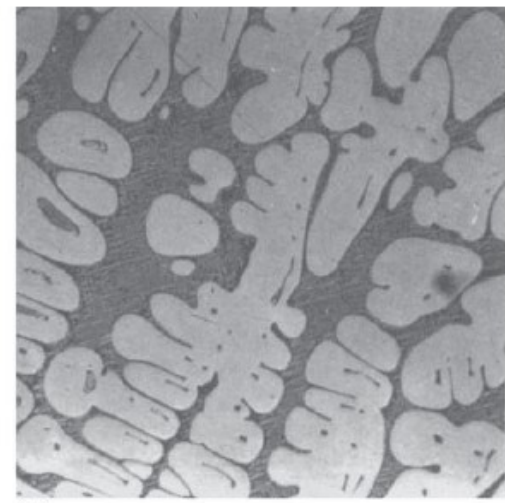

(c)

Figura 9 - Três estágios da reação peritética em um aço rápido direcionalmente solidificado.

Em (a), estrutura do estágio inicial. Cinza escuro é austenita, branco ferrita. A estrutura mosqueada é líquido resfriado.

Em (b), transformação peritética subsequente de (a).

Em (c), transformação peritética posterior de (b). Cinza escuro no meio da ferrita branca é o novo liquido (18).

Durante a transformação peritética ocorre enriquecimento interdentrítico por fenômeno de segregação. Esta é devida à formação da austenita $\gamma \mathrm{CFC}$ a partir da ferrita $\delta \mathrm{CCC}$, quando ocorre uma contração volumétrica, que se adiciona à contração natural do aço em solidificação. Desta contração origina-se a lacuna de ar existente entre o aço em solidificação e as paredes do molde provocando uma maior separação entre ambos.

Essa deformação elástica é provocada pelas diferenças de densidades entre a austenita CFC e a ferrita CCC. A ferrita $\delta$ é da ordem de 2-3\% maior em volume molar do que a austenita $\gamma$.

Desde que aço líquido é igualmente presente, este é enriquecido em conteúdo elementos dissolvidos tais como ligas. Teores inferiores de carbono reduzem a tendência à segregação como esquematicamente mostrado na Figura 10.

Nessa figura, a região com hachuras horizontais mostra segregação durante a solidificação. Totalmente em negrito, enriquecimento interdentrítico durante a reação peritética. A região com hachuras horizontais a notável homogeneização em ferrita $\delta$ devida à sua mais elevada difusividade em relação à austenita $\gamma$. O coeficiente de difusão no ferro $\gamma \mathrm{CFC}$ é substancialmente menor do que em outras fases. A fase $\gamma$ CFC é uma rede cristalina compacta mais densa do que a rede CCC da ferrita $\delta$. 

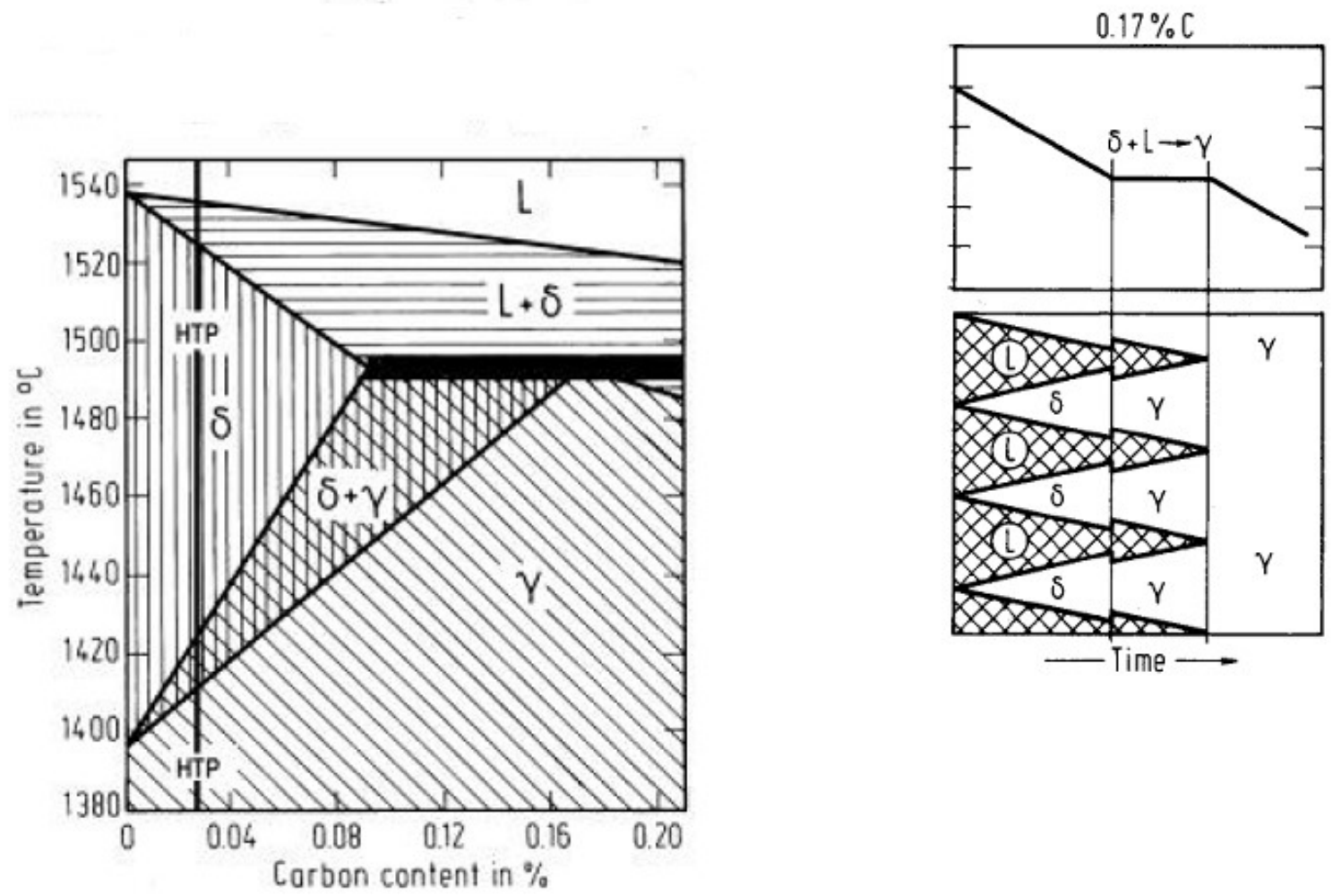

Figura 10 - Classificação da severidade de segregação e demonstração esquemática da reação peritética (19). HTP - High Temperature Processing

A redução dos teores de carbono dissolvido é refletida em diversas melhorias no desempenho dos aços, tais como tenacidade e ductilidade, condições de soldabilidade e redução na segregação como nas regiões de linhas de centro nas placas $(20,21)$.

Essa redução na tendência à segregação manifesta-se em aços de teores médios de carbono sob a forma de enriquecimento durante a reação peritética quando ocorre a contração adicional devida à formação da austenita CFC a partir da ferrita CCC. Desde que o aço líquido é também presente nessa reação, é naturalmente enriquecido pelo conteúdo presente de ligas.

$\mathrm{Na}$ redução dos teores de carbono, a segregação interdentrítica é igualmente reduzida pela redução do intervalo de solidificação e o maior intervalo de ferrita delta, que favorece a homogeneização à medida que o coeficiente de difusão dos elementos na ferrita é 100 vezes maior do que na austenita que é uma rede cristalina mais densa (19).

O favorecimento às condições de melhor soldabilidade devido aos menores tores de carbono, pré-aquecimento e o fenômeno de zonas termicamente afetadas é assunto muito bem explorado sob os aspectos de equivalência em carbono, como por exemplo em (22). 


\subsubsection{Lingotamento contínuo}

O processo de lingotamento contínuo é atualmente dominante no setor siderúrgico, substituindo quase que completamente o lingotamento convencional e abrangendo a quase totalidade dos tipos de aços comercialmente produzidos.

Restrições pontuais podem ser encontradas em algumas qualidades de aços muito carregados em elementos de liga, normalmente processados em reduzidas escalas de produção.

Sem dúvida a ideia de tornar o processo de lingotamento em uma operação contínua e não intermitente como no modo convencional se tornou um exemplo de tecnologia de processamento bem-sucedido e dominante. O período decorrido desde seu advento em 1887 (23) até os dias de hoje traduziu-se no desenvolvimento e incorporação de novas tecnologias de processos; nos avanços nas concepções de projeto de equipamentos; nos atuais sistemas integrados de automação, supervisão, informação e controle; no contínuo aprimoramento da qualidade de produto e, sobretudo, no acervo de conhecimentos científicos e tecnológicos sobre os fenômenos que regem esse processo em contrapartida ao lingotamento convencional.

Cabe observar, entretanto, que o processo de lingotamento contínuo só se tornou tecnicamente viável para os aços com a incorporação de mecanismos de oscilação do molde. Ligas não ferrosas não necessitam de moldes oscilantes para serem continuamente lingotadas.

A esses desenvolvimentos aliam-se as modernas tecnologias de metalurgia primária e secundária que facultaram a quase completa superação de ocorrências de falhas de processamento no material lingotado que podem comprometer toda uma operação, como as perfurações de veio e de desvios de qualidade como defeitos superficiais e internos que podem afetar a qualidade e as propriedades dos produtos finais laminados e conformados.

Uma moderna máquina de lingotamento contínuo de placas encontra-se capacitada a produzir de forma estável mais de $1 \mathrm{M} \mathrm{t} /$ ano de placas de aço por veio de lingotamento, Figura 21.

A estabilidade operacional e de qualidade de produto permitem as práticas operacionais de enfornamento a quente das placas lingotadas, as operações de laminação direta e as mais recentes tecnologias de lingotamento contínuo de placas finas diretamente acoplado a laminadores de tiras a quente que permitiram transformar aciaria e laminação em uma única operação contínua (24).

Desse acervo acumulado de conhecimentos analíticos e empíricos sobre o comportamento dos aços a elevadas temperaturas emergiu o conceito de lingotabilidade aplicados a estas ligas, definido como uma medida da maior ou menor suscetibilidade a falhas qualitativas de desempenho que estes apresentam quando continuamente lingotados. 
Esse conceito de lingotabilidade advém do extenso conhecimento ora disponível sobre o relevante papel exercido pelos distintos tipos de aços e suas respectivas composições químicas nesse contexto, devido primordialmente à identifícação e diagnóstico das causas e consequências dos desvios de qualidade como resumidamente apresentados na Figura 2. Além desses defeitos, citam-se também os de geometria como romboidades, abaulamentos e desvios de quadratura.

No caso específico dos aços peritéticos, sua maior sensibilidade à formação de trincas durante o processamento demanda que sejam tomadas medidas preventivas quanto a ajustes nas velocidades de lingotamento e inspeção detalhada do produto lingotado, eventualmente destinado a operações de escarfagem superficial.

Igualmente a considerar são as questões relacionadas com as condições de resfriamento do material em lingotamento, como as vazões de água nos moldes, o adequado comprimento e conicidade destes sob a ótica das lacunas de ar entre as paredes do molde e a superfície do material em lingotamento, e a própria geometria (raio) das quinas que esfriam mais rapidamente que o restante do material, favorecendo o aparecimento de trincas de canto (corner cracks).

Emergem do mesmo modo as condições de resfriamento das placas como lingotadas. Se expostas ao tempo sob condições de rápido resfriamento, a ocorrência de transformações martensíticas é inevitável nas superfícies expostas.

No caso das aços peritéticos, a deterioração da lingotabilidade desses tipos de aços deve-se fundamentalmente ao fenômeno de contração adicional oriunda das transformações $\gamma / \delta$ que é acrescida à própria contração natural do material em solidificação.

A formação de trincas em aços continuamente lingotados provocadas por tensões de ordem térmica e mecânica é atribuída a fenômenos de zonas de redução de ductilidade e de inferior resistência à tração.

As Figuras 12 e 13 ilustram esse aspecto de reduzida ductilidade apresentada pelos aços logo abaixo do solidus, devida a microsegregações de elementos residuais como $\mathrm{S}$ e $\mathrm{P}$ nas interfaces de dendritas em solidificação.

A ductilidade permanece efetivamente nula até que o líquido interdentrítico comece a se resfriar. Qualquer alongamento aplicado ao material nessa faixa de temperatura poderá promover a propagação de trincas a partir das frentes de solidificação entre as dendritas como ilustrado na Figura 14 (25). 


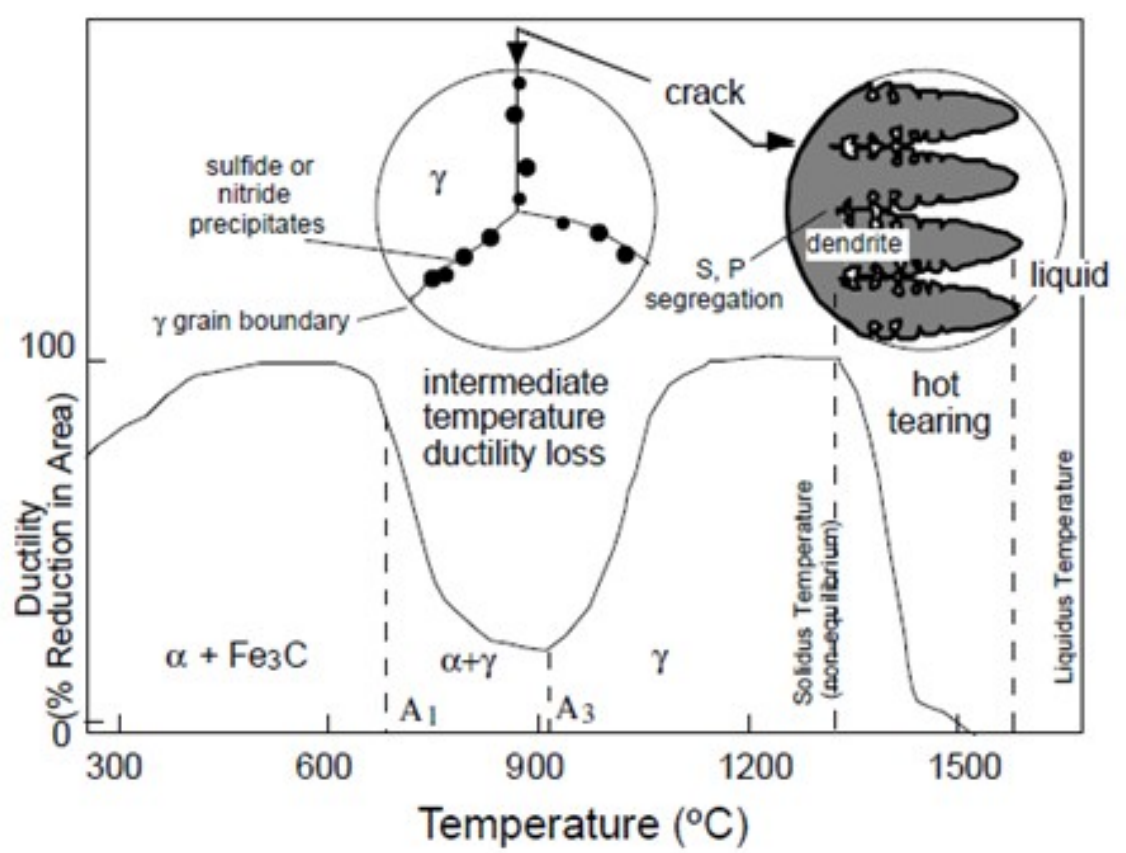

Figura 11 - Representação das zonas de reduzida ductilidade

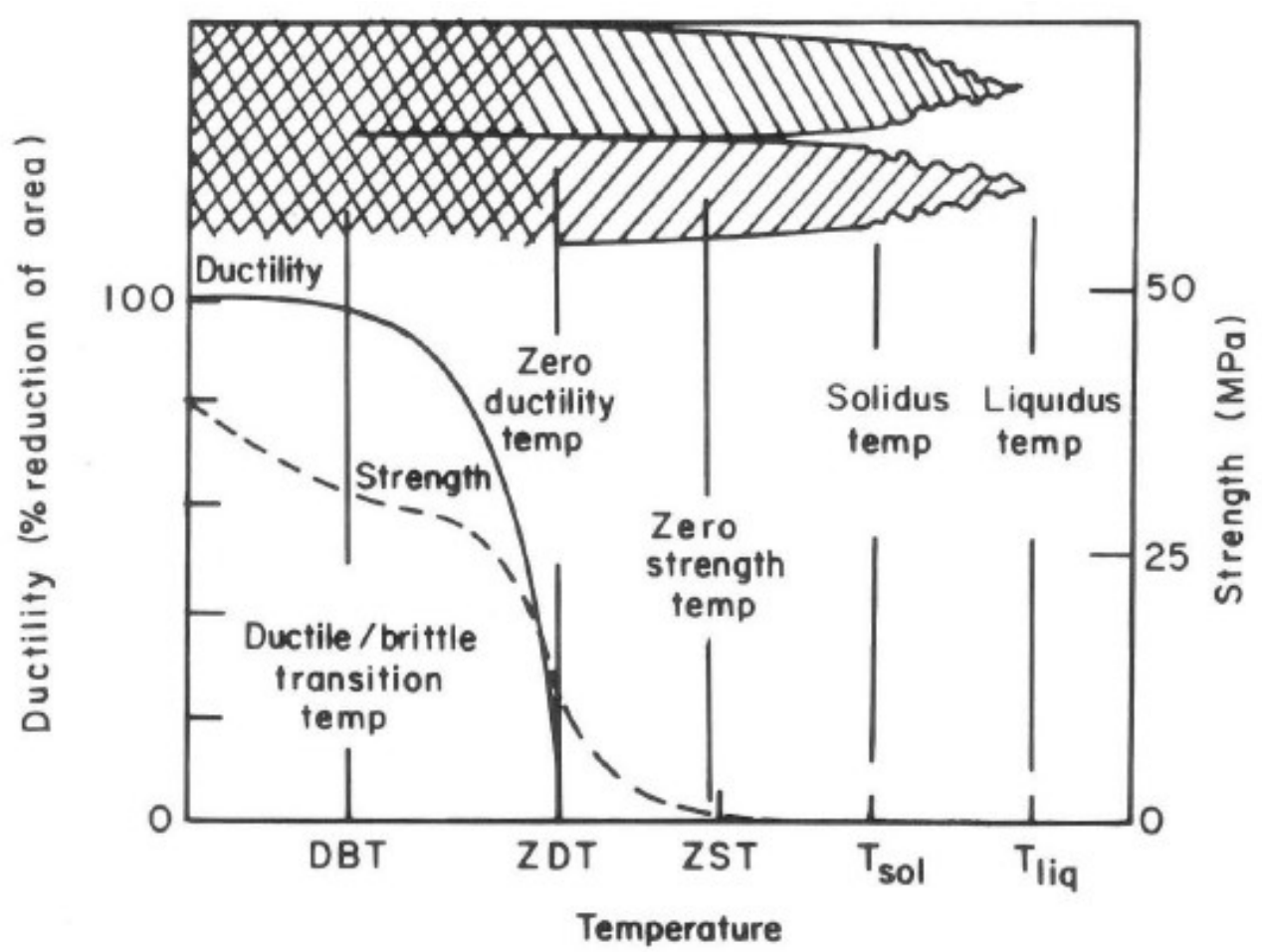

Figura 12 - Apresentação esquemática da interface sólido/líquido durante o lingotamento 


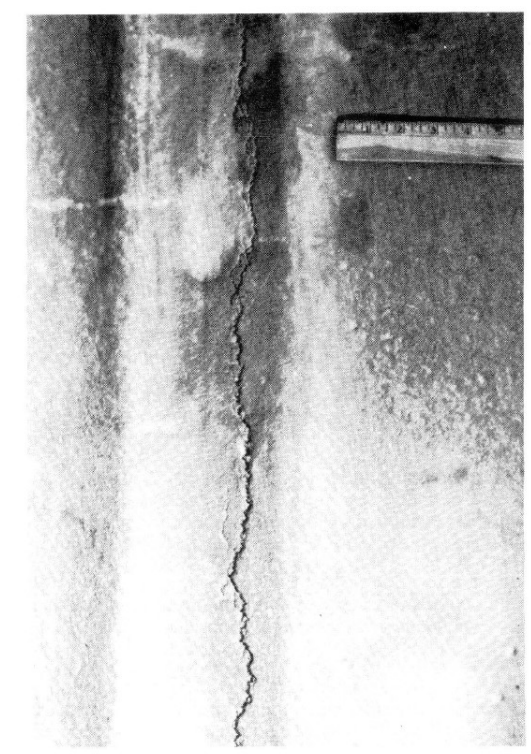

Figura 13 - Aparência típica de trinca de resfriamento em um lingote de $25 \mathrm{t}$ atribuída ao fenômeno de reduzida ductilidade dos aços a elevadas temperaturas

O material em lingotamento, como no caso das placas de aço, sofre os efeitos combinados e sobrepostos de distintos fenômenos de ordem térmica, metalúrgica e de esforços mecânicos aplicados:

- Fatores de material - $\gamma / \delta$, altos teores de $\mathrm{S}$ e insuficiente relação $\mathrm{Mn} / \mathrm{S}$

- Tensões térmicas - resfriamentos não uniformes

- Tensões mecânicas - fricção e flutuação do nível de aço líquido no molde, pressão dos rolos, pressão ferrrostática, desalinhamentos mecânicos e operações de curvamento e endireitamento.

\section{(i) Transformações $\gamma / \delta$}

Baixa ductilidade a quente em aços lingotados é reportada a temperaturas em torno de $1173 \mathrm{~K}\left(900^{\circ} \mathrm{C}\right)$ devido a transformações $\gamma / \delta$. Essa faixa de temperatura é frequentemente encontrada na superfície de placas na área de endireitamento (26).

\section{(ii) Tamanho do grão da Austenita}

Um importante parâmetro que afeta a ductilidade dos aços a elevadas temperaturas e a suscetibilidade a trincas é o tamanho do grão da austenita, ao qual são atribuídos muitos defeitos em produtos continuamente lingotados.

Efeitos provenientes da oscilação do molde como as marcas de oscilação e variações dos níveis do metal líquido em solidificação conduzem ao retardamento das condições de resfriamento da superfície do veio em lingotamento, que por sua vez resulta na formação de grãos grosseiros de austenita (coarse austenite). 
Evidências indicam que grandes grãos de ferrita delta são massivamente transformados em grossos grãos de austenita que se formam rapidamente. Após rápido resfriamento, a austenita se transforma em ferrita fina nos contornos de grão. A essa formação de um filme fino de ferrita nos contornos de grãos da austenita é atribuído um relevante papel na redução da ductilidade a quente. A tenacidade da ferrita é inferior à da austenita (27).

À formação de maiores tamanhos de grão da austenita é atribuída uma marcante dependência do teor de carbono, provocada por maiores temperaturas de formação desta fase (28). Os grãos de austenita crescem rapidamente depois da completa transformação ou solidificação na fase $\gamma$ à medida que o efeito de ancoragem (pinning) da segunda fase como ferrita $\delta$ ou fase líquida no contorno de grão $\gamma$ foi aliviado.

Uma solidificação superficial desigual no molde devida a transformações peritéticas produzirão microestruturas $\gamma$ muito mais grossas por causa do retardamento local do resfriamento, Figura 14.

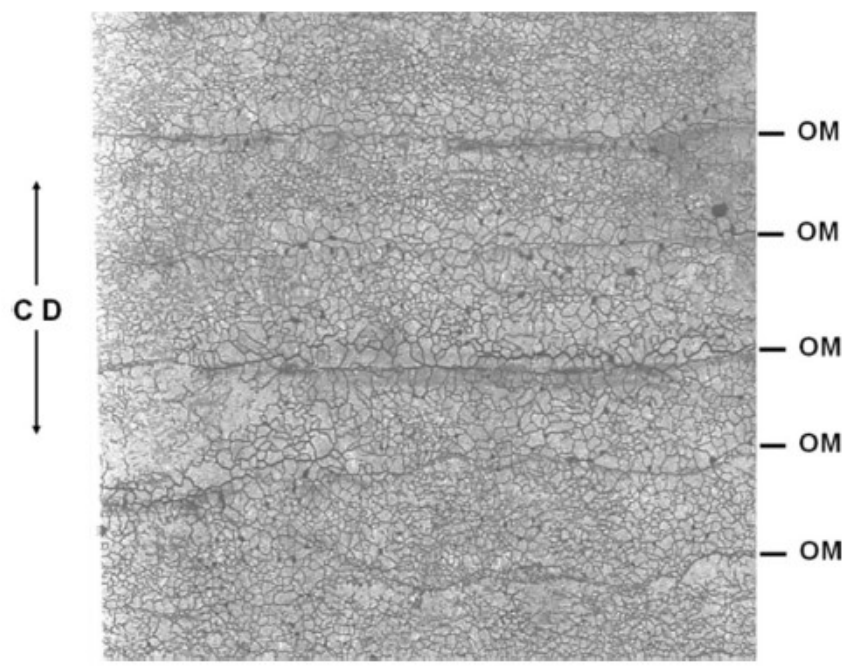

Figura 14 - Grandes grãos de austenita formada anteriormente. CD - direção de lingotamento. OM - marcas de oscilação (29)

Mecanismos de formação de trincas transversais superficiais no material lingotado são explicados analogamente pelo fenômeno de grande crescimento de grãos na superfície devido a altas temperaturas localizadas e alongamento, especialmente abaixo de marcas de oscilação.

Durante o lingotamento, precipitados começam a se formar primeiramente ao longo desses grãos engrossados e microtrincas são então iniciadas nesses contornos enfraquecidos e se propagam em trincas visíveis na superfície do veio, como ilustrado na Figura 15. 


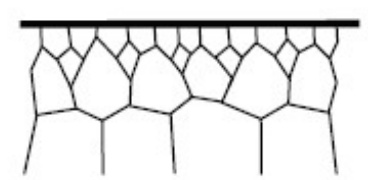

Fase I - Solidificação normal na parede do molde. Grãos de superfície são pequenos, mas altamente orientados

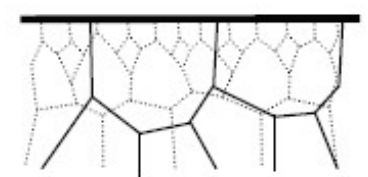

Fase II - Os grãos de superfície "explodem" devido à elevada temperatura $\left(>1350^{\circ} \mathrm{C}\right)$ e alongamento, especialmente na base de marcas de oscilação profundas

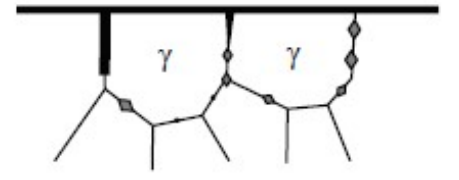

Fase III - Precipitados começam a formar ao longo dos contornos de grãos explodidos. Microtrincas iniciam-se nas fronteiras enfraquecidas

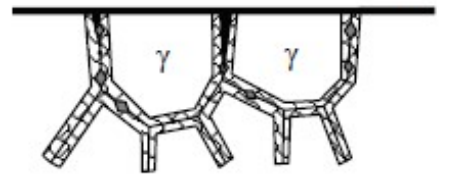

Fase IV - A transformação da ferrita começa e novos precipitados se formam nos contornos. Microtrincas existentes crescem e novas se formam

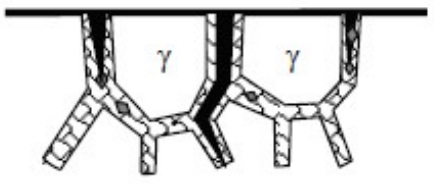

Fase IV - No endireitamento, microtrincas se propagam a se transformam em trincas maiores, primariamente na superfície de topo do veio

Figura 15 - Típico mecanismo de tormaçao de trıncas superficiais (30)

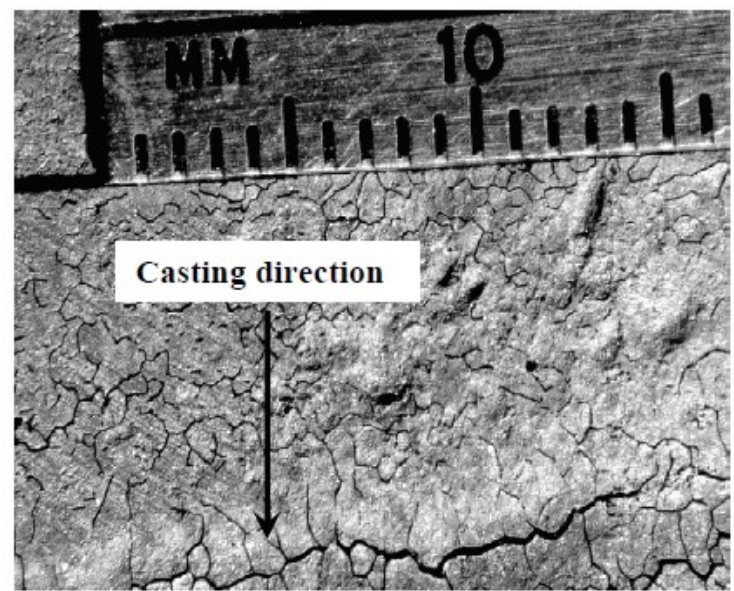

Figura 16 - Trinca transversal na base de uma marca de oscilação em uma placa de aço $0,2 \% \mathrm{C}(30)$

Outro fator reportado como fonte originária na formação de trincas internas são as segregações locais positivas, como mencionado anteriormente (p.17). Segregações locais positivas são referidas como o enriquecimento local de um constituinte de um material, como o carbono, em uma superfície livre ou interface. Uma das razões atribuídas ao transporte de líquidos segregados são as diferenças de densidades no metal devido a mudanças de temperatura e composição.

Um mecanismo proposto para a formação de trincas segundo esse fenômeno de segregação local considera que no menisco do aço líquido, quando a extremidade da casca parcialmente solidificada é dobrada periodicamente durante a oscilação do molde, líquido "sujo" é espremido para fora e acumulado no vale de uma marca de oscilação formando segregação local. Trincas iniciam-se nessa parte fraca da casca sob a ação de tensões internas e se propagam ao longo dos contornos de grãos da austenita. 


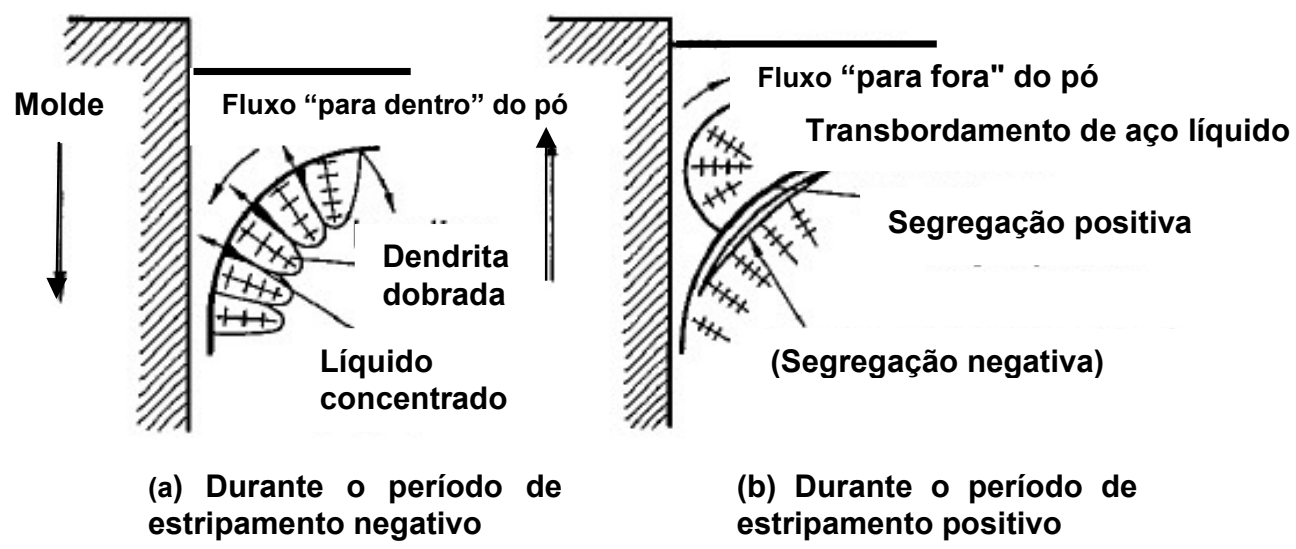

Figura 17 - Mecanismo de formação de segregação no menisco do aço líquido

\section{(iii) Relações Mn/ S}

A influência do elemento enxofre na ductilidade a quente da austenita é conhecida e reportada como, por exemplo, em (31).

Dessa influência decorre o estabelecimento das relações correlatas de $\mathrm{Mn} / \mathrm{S}$ se inferiores a 20 ou o teor de enxofre maior do que $30 \mathrm{ppm}$ sem adição de manganês. Fraturas intergranulares ocorrem devidas à segregação nos contornos de grãos da austenita e consequente perda de ductilidade.

Algumas ligas, como as de ferro e carbono, apresentam tendência de sofrerem separação ao longo dos contornos de grãos quando submetidas a esforços mecânicos em temperaturas próximas às de fusão provocada por teores elevados de enxofre. Ferro e enxofre formam um eutético de baixa temperatura de fusão sob a forma de sulfeto de ferro que produz uma fase líquida nos contornos de grãos. A influência benéfica de mais elevados teores de $\mathrm{Mn}$ em relação ao de $\mathrm{S}$ deve-se ao efeito de ancoragem que aquele exerce sobre o último pela formação de $\operatorname{MnS}(32,33)$.

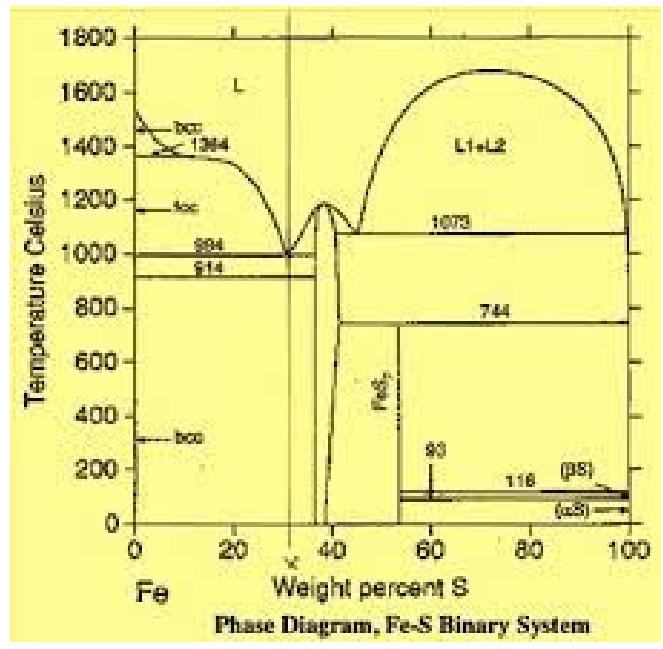

Figura 18 - Diagrama binário Fe-S (34)

(iv) Fricção e flutuação do nível de aço líquido no molde 
No processo de lingotamento contínuo, o molde oscila enquanto que o veio é continuamente extraído. Uma fricção além das características de resistência mecânica do material em processo de solidificação e as paredes do molde podem conduzir a perfurações de veio por colagem (sticking breakout). Perfurações de veio por colagem ocorrem quando a casca solidificada quebra-se e o aço líquido não pode mais ser contido pela parte já solidificada.

No caso das máquinas de lingotamento contínuo produtoras de placas de aço, a ação lubrificante entre a casca recém-solidificada e o molde é provida pelos denominados pós fluxantes, que são escórias sintéticas constituídas por uma mistura complexa de óxidos, minerais e materiais carbonosos. Essas escórias, são adicionadas no interior do molde no topo do metal líquido e formam sucessivas camadas, como ilustrado na Figura 19, desempenhando adicionalmente outras funções à parte da lubrificação tais como prevenção de oxidação, absorção de inclusões e isolamento térmico.

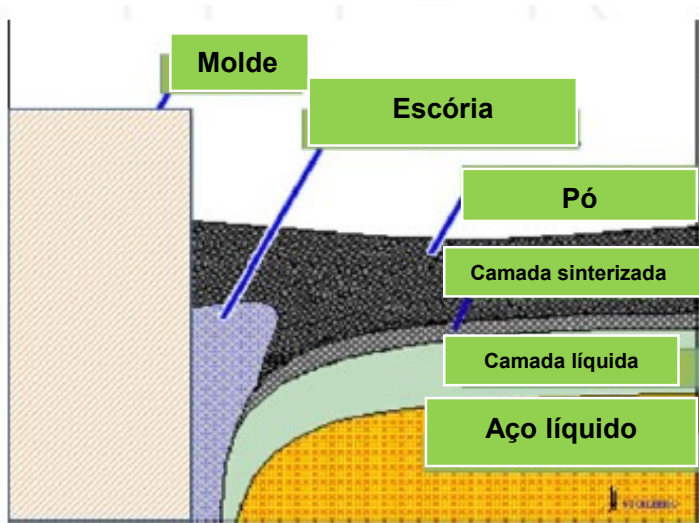

(A)

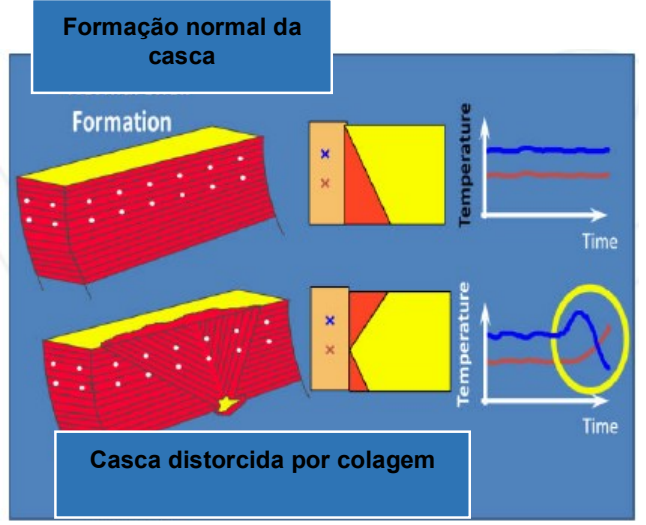

(B)

Figura 19 - Pó fluxante (A) e fenômeno de colagem (B) (35)

Um fenômeno que comumente ocorre no lingotamento contínuo de placas é a flutuação periódica no nível de aço líquido no molde, o qual pode conduzir a qualidade superficial inferior e até a perfurações de veios devido ao apresamento do pó fluxante.

Em ocorrências de entupimentos e desentupimentos nas válvulas submersas surgem fluxos erráticos de aço líquido para o interior dos moldes e efeitos inconstantes de inchamento das placas podem acontecer induzidos por variações das espessuras da casca recém-solidificada ou desalinhamentos dos rolos-guia. As alterações volumétricas no núcleo líquido devido ao inchamento inconsistente na zona de resfriamento secundário é a maior causa das oscilações de nível no molde. $\mathrm{Na}$ saída do veio do molde ocorre uma crescente pressão ferrrostática que favorece a formação de inchamento entre os rolos-guia.

Um crescimento desigual da casca solidificada é frequentemente causado pela formação periódica da lacuna de ar por contração de solidificação e pressão ferrostática do aço líquido. 
A contração de solidificação induzida pelas transformações $\gamma / \delta$ são incluídas e até dominantes nesse fenômeno de flutuação periódica no nível de aço líquido no molde (36).

Entupimentos de válvulas refratárias são usualmente provocados por obstruções causadas por deposição de óxidos resultantes da ação de elementos desoxidantes adicionados.

$\mathrm{Na}$ moderna operação de máquinas de lingotamento continuo para placas, flutuações de nível acima dos padrões internamente estipulados ou impostos pelos adquirentes externos das mesmas são considerados desvios severos de qualidade e as placas resultantes encaminhadas para inspeções de qualidade, escarfagem para remoção de defeitos superficiais ou até eventualmente sucateadas.
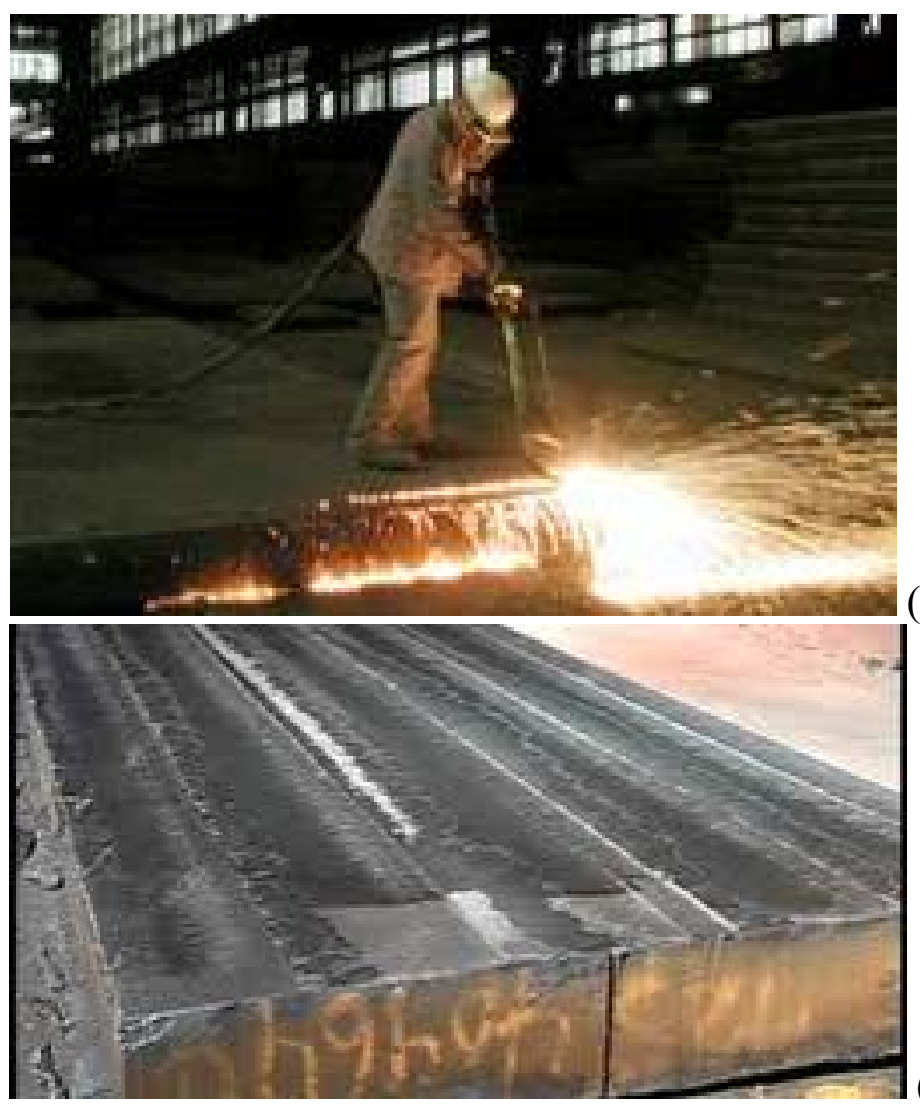

(A)

(B)

Figura 20 - Operação de escarfagem manual (A) e placas escarfadas (B)

\section{(v) Operações de dobramento e endireitamento}

As modernas máquinas de lingotamento contínuo, como as que processaram as placas das quais se originaram a série de defeitos de laminação a quente em pauta, são concebidas como instalações de molde reto com subsequentes operações de dobramento do material processado. Posteriormente esse sofre as necessárias operações de endireitamento, como ilustrado na Figura 21. Essa concepção de moldes retos deriva-se do propósito de fomento à flotação e absorção de inclusões não metálicas pelos pós fluxantes. 
Essas inclusões não metálicas podem incluir aprisionamentos de escória (slag entrapment). As máquinas de moldes curvos tendem a promover a concentração de inclusões na face superior do material lingotado.

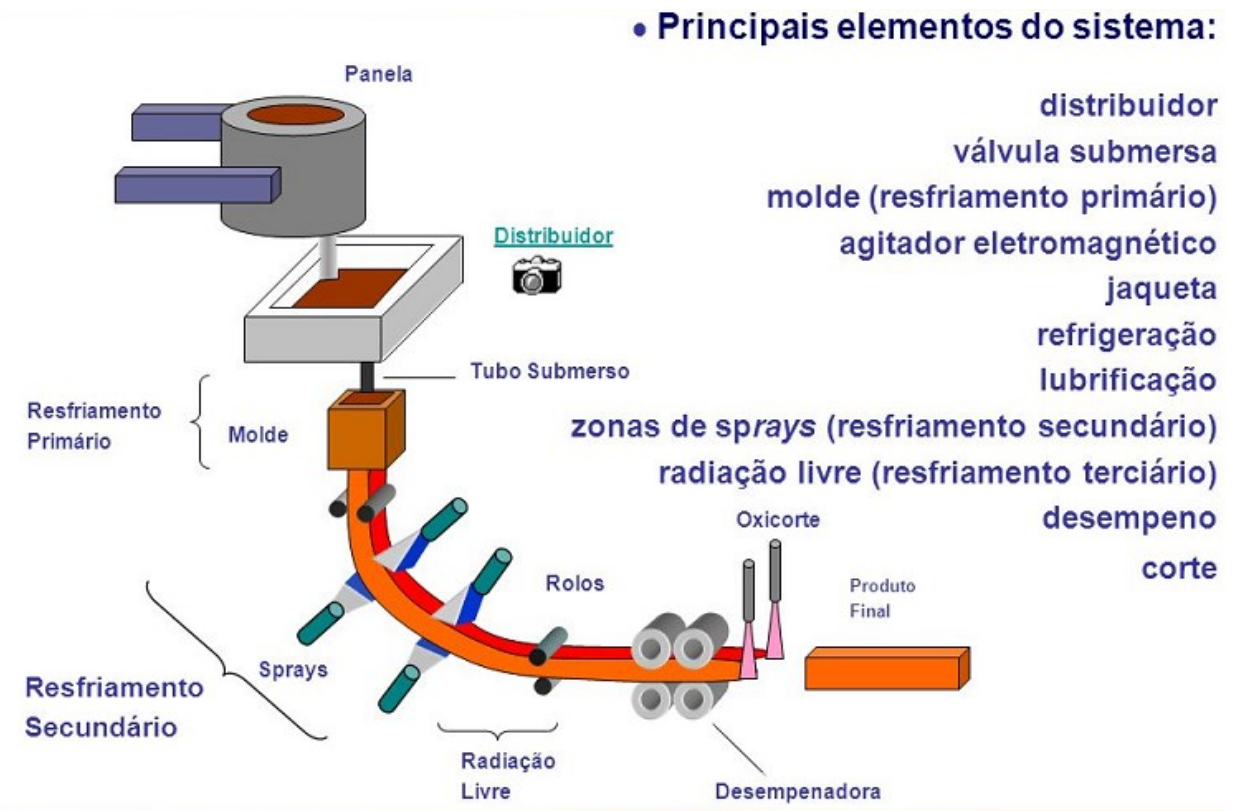

Figura 21 - Representação esquemática de máquina de lingotamento contínuo de molde reto com operações de dobramento e endireitamento

Essas operações de dobramento e endireitamento impõem esforços mecânicos ao material em lingotamento que fica então sujeito às tensões resultantes, dando margem à geração de trincas transversais. Quanto maior for o nível e a taxa de alongamento e menor o limite de resistência mais favorável é essa geração de trincas.

No dobramento, essas tensões são compressivas na superfície superior do veio e trativas na inferior. No endireitamento ocorre o inverso. São tratativas na parte superior e compressivas na inferior.

Trincas transversais, usualmente intergranulares podem se formar se a ductilidade a quente do material lingotado é baixa. Essas trincas podem ser encontradas nos contornos de grãos da austenita anterior (37).

\section{(iv) Pressão ferrrostática}

Embora as placas em lingotamento sofram contratação no molde, da ordem linear de $2,5 \%$ (38), tensões decorrentes da pressão ferrrostática exercida em suas faces estreitas quando o veio de lá emerge podem provocar alterações dimensionais na largura das placas de modo similar ao fenômeno de alargamento (broadening), que é a deformação do material na direção vertical da força no processo de laminação.

Esse fenômeno pode associar-se ao efeito adicional de inchamento lateral. Essas alterações dimensionais no material lingotado, dependendo de sua gravidade, cria problemas nas operações subsequentes de laminação a quente, Figura 22. 


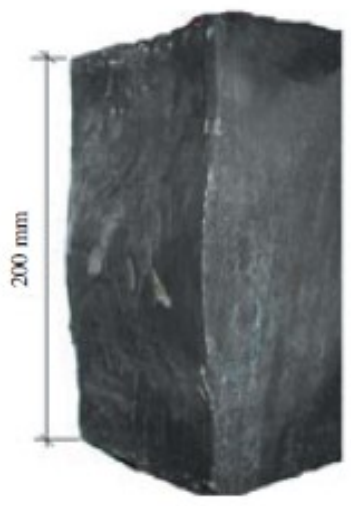

(a)

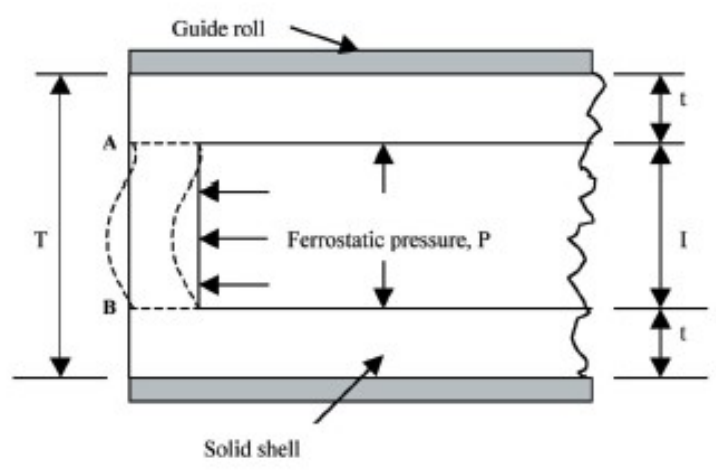

(b)

Figura 22 - Exemplo de inchamento lateral na face estreita de placa de espessura $200 \mathrm{~mm}$ continuamente lingotada e sua representação esquemática (38)

A intensidade de alargamento das placas relaciona-se proximamente com as velocidades de lingotamento, talvez devido às alterações de temperatura com a velocidade. Com o acréscimo na temperatura da placa, a ductilidade aumenta e sua resistência a pressões externas decresce como indicado na Figura 23.

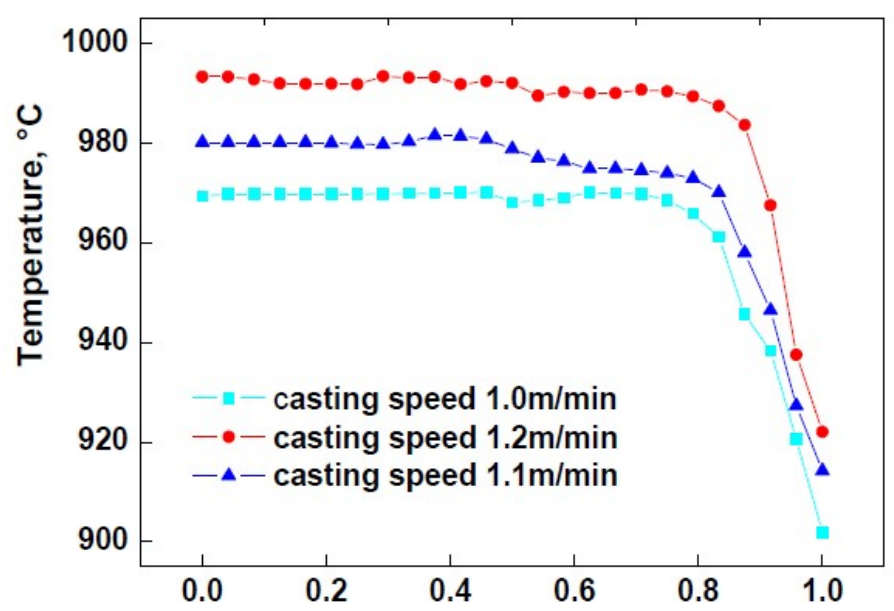

Figura 23 - Temperatura na superfície da placa em função da distância em metros (39)

A Figura 24 exemplifica a formação de trincas internas em placa de aço reveladas por macrografia e relacionadas com a existência de zona de baixa ductilidade nos aços acima de $1.340^{\circ} \mathrm{C}$.

Essas trincas são atribuídas a tensões geradas na casca em solidificação devidas à ação das pressões ferrrostática e dos rolos-guia e operações de dobramento e endireitamento. 


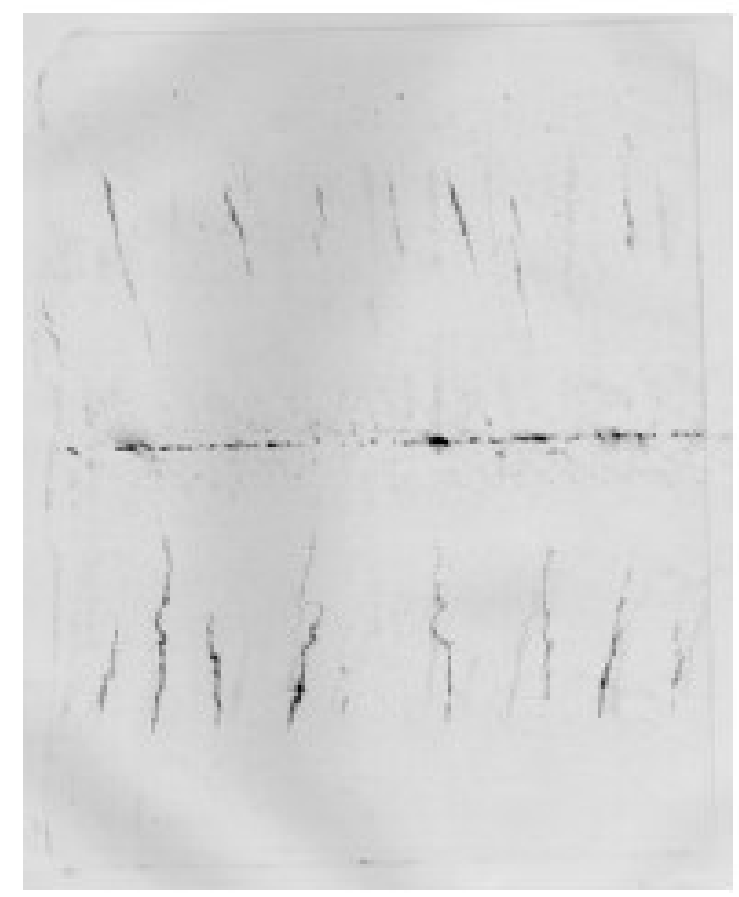

Figura 24 - Trincas internas em placa de aço (40)

Exemplos de formação de ocorrências de trincas em placas de aço SAE 1020, 260 $\mathrm{mm}$ de espessura destinadas a laminação a quente de produtos longos, são mostrados na Figura 25. As condições de processamento em aciaria dessas placas são relatadas em prosseguimento.

No caso das trincas superficiais indicadas nos dois primeiros exemplos, estas presumivelmente afloraram à superfície posteriormente às inspeções rotineiras de qualidade, talvez durante seu resfriamento e foram assim embarcadas para a empresa laminadora (41).

Nas demais são trincas detectadas em inspeções realizadas após as operações de oxicorte das placas e a manifestação dos defeitos de laminação.

Uma hipótese é que estas estivessem internamente latentes nas placas como lingotadas e foram exacerbadas por efeitos de zonas termicamente afetadas durante as operações de corte. A terceira placa sofreu esmerilhamento superficial de modo a evidenciar a trinca (42).

Tanto nesses exemplos quanto no anterior as placas não sofreram efeitos aparentes de severidade de marcas de oscilação ou também abaulamentos. 

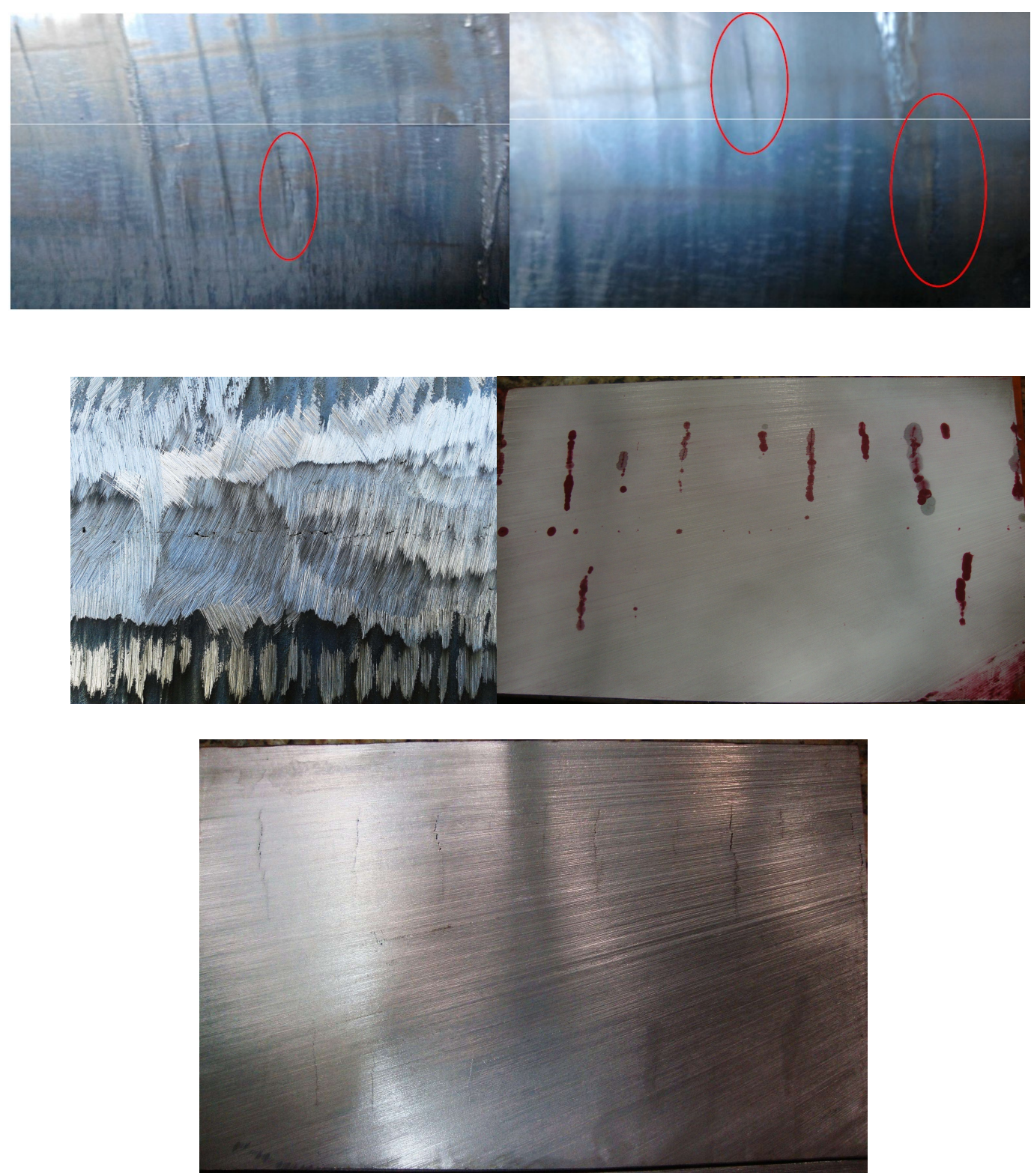

Figura 25 - Exemplos de trincas em placa de aço SAE 1020 destinadas a laminação a quente

\subsection{Da sucessão de defeitos encontrados em laminados a quente a partir de placas de aço SAE 1020}

\subsubsection{Parque industrial de empresas laminadoras}

No Brasil encontra-se um parque industrial de empresas que se dedicam à laminação a quente de semiacabados fornecidos por terceiros como placas de aço. Esse setor compõe-se de mais de dez empresas totalizando uma capacidade de produção da ordem de 30-36.000 t/mês conforme dados de 2013 (43). 
A linha de produção dessas empresas compreende basicamente produtos estruturais tais como barras chatas, barras redondas, barras quadradas, cantoneiras e até perfis especiais destinados à indústria automobilística e de máquinas, Figura 26.

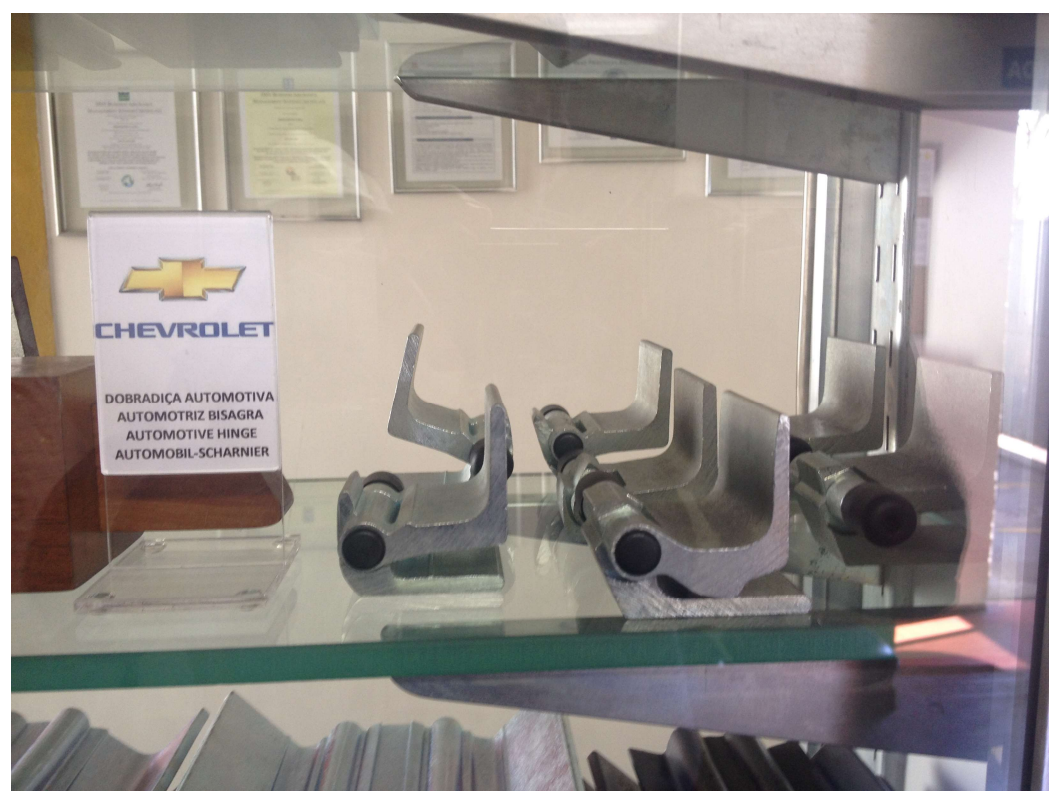

Figura 26 - Exemplo de perfis especiais fabricados por empresa laminadora (44)

Os produtos laminados por essas empresas quando destinados a aplicações estruturais obedecem genericamente ao disposto na Norma Brasileira ABNT aplicável (45). Essa norma preconiza, sob o aspecto de propriedades mecânicas, cinco graus de aços a seguir reproduzidos:

\section{Grau do aço
Resistência ao escoamento mínima (MPa)

$\begin{array}{cc}\text { BR 190 } & 190 \\ \text { MR 250 } & 250 \\ \text { AR 350 } & 350 \\ \text { AR 350 COR } & 350 \\ \text { AR 415 } & 415\end{array}$

\section{Resistência à ruptura (MPa)}

mín 330

400-560

mín 450

mín 485

mín 520

\section{Alongamento mínimo após ruptura \% lo}

$(*)=200 \mathrm{~mm}$

22,0

20,0

18,0

18,0

16,0

(*) lo é o comprimento da base de medida para determinação do alongamento

O tipo de aço mais adotado por esses laminadores independentes é o popular SAE 1020 à medida que atende ao disposto na citada norma técnica. A composição química em \% de peso do SAE 1020 é a que segue \% (46):
C
$0,18-0,23$
Mn
$\mathbf{0 , 3 0 - 0 , 6 0}$
P máx.
0,04
S máx.
0,05 


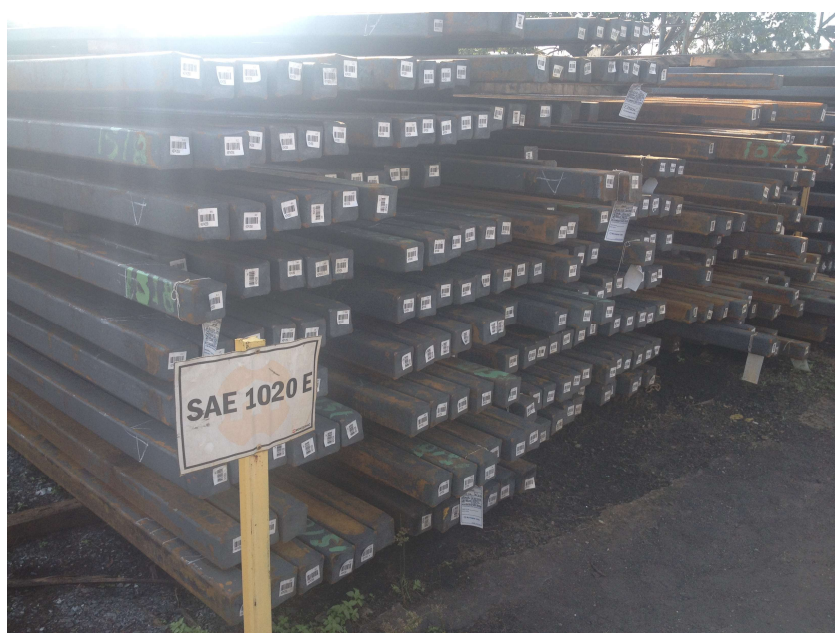

Figura 27 - Tarugos continuamente lingotados em aço SAE 1020 destinados a laminaçao a quente (44)

Essas empresas genericamente operam laminadores abertos semicontínuos como ilustrado na Figura 28. A operação de desbaste do material de entrada é feita em um laminador desbastador (roughing mill) como também ilustrado nessa Figura. Em tais tipos de trens de laminação ocorrem intervenções manuais:

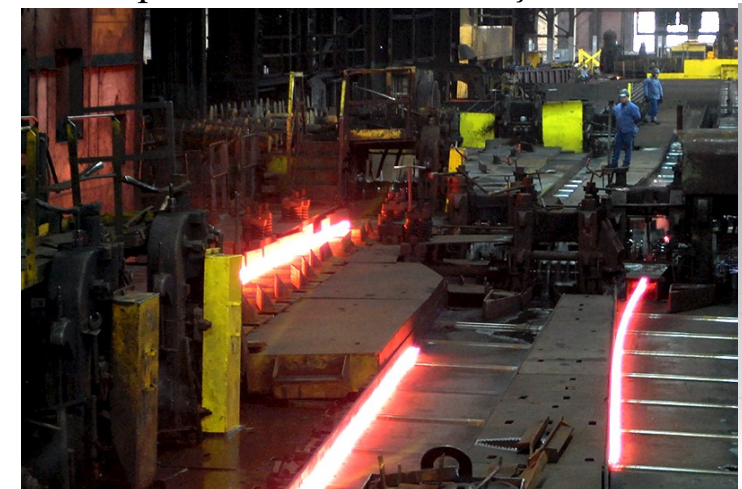

(A)

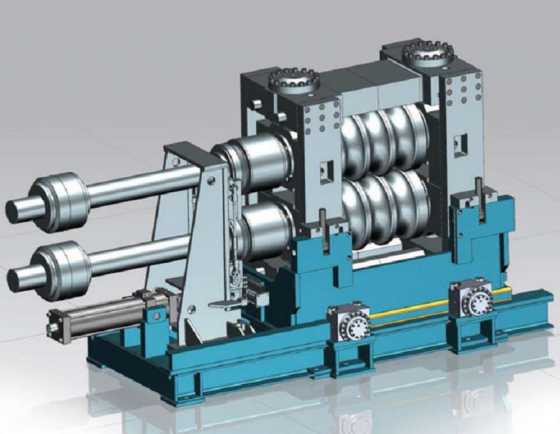

(B)

Figura 28 - Laminação de produtos longos (A) e desbastador (B)

Na laminação de produtos planos o material é processado entre dois cilindros que promovem as reduções de espessura e alongamento do material no sentido da laminação. Ou seja, o material preserva sua geometria original retangular entre os passes subsequentes de laminação.

Na laminação de produtos longos, por sua vez, o material em laminação altera sua geometria a cada passe Figura 28 (B) (47). Ou seja, na laminação de produtos longos o material em processamento é mais submetido a esforços mecânicos periféricos do que na laminação de planos. 
Interessante igualmente observar a variação do raio do cilindro ao longo dos canais, sabendo-se que ao longo da superfície de contato entre o rolo e o material atuam sobre este duas forças: radial (torque) e tangencial friccional.

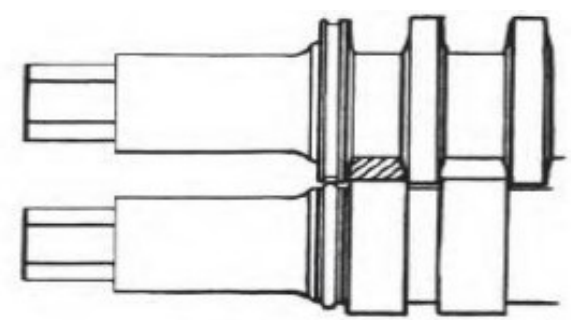

(A)

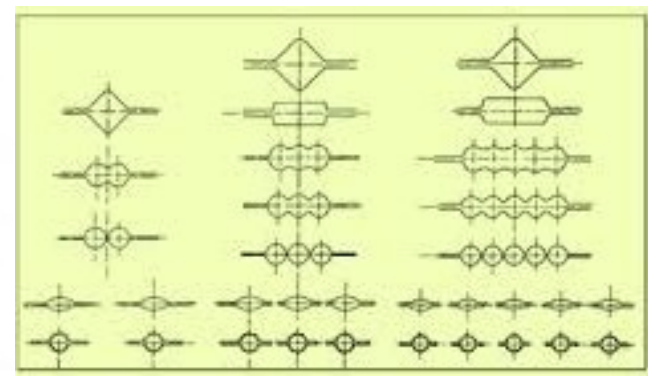

(B)

Figura 29 - Passes de laminação de barras

Quando a matéria-prima são placas de aço, estas são previamente cortadas para a formação de blocos ou tarugos de seção quadrada de $130 \mathrm{~mm}$ x $130 \mathrm{~mm}$ como mostrado na Figura 27. O corte longitudinal das placas é feio em máquinas automatizadas de oxicorte como mostrado na Figura 30.

Placas de $260 \mathrm{~mm}$ de espessura como as do em pauta são cortadas em duas etapas. Na primeira vez sob a forma de blocos retangulares de $130 \mathrm{~mm} \times 260 \mathrm{~mm}$ e depois tombadas para uma segunda etapa de cortes longitudinais ao meio na dimensão $260 \mathrm{~mm}$, conformando deste modo tarugos $130 \mathrm{~mm} \times 130 \mathrm{~mm}$.

Para empresas que dispõem de um laminador mais poderoso, como a CIAFAL, o material de entrada são blocos de $260 \mathrm{~mm}$ x $260 \mathrm{~mm}$ demandando então apenas uma única etapa de cortes longitudinais das placas (42).

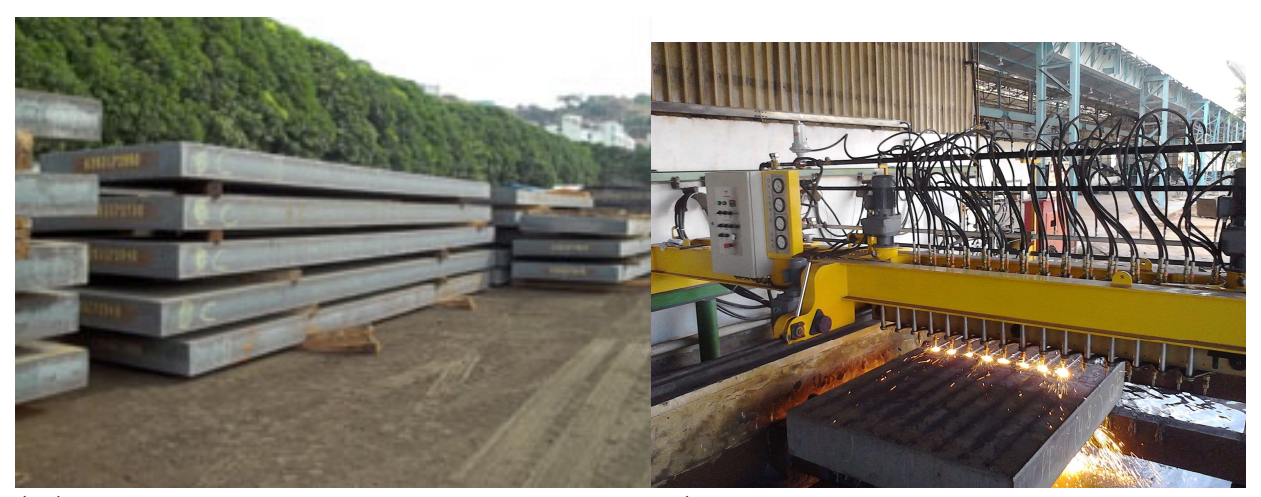

(A)

(B)

Figura 30 - Placas de aço (A) e máquina de corte (B) (48)

\subsubsection{Processamento das placas}

A planta de aciaria onde as placas de aço SAE 1020 em questão foram processadas compõe-se de duas áreas funcionais de metalurgia, primária e secundária, e de lingotamento contínuo. A mistura de produtos processada por essa aciaria abrange aços para aplicações na indústria automobilística, máquinas e equipamentos, setor petroquímico e embalagens metálicas, abrangendo aços ao carbono, microligados, ultrabaixos teores de carbono (intersticial free) para 
estampagem ultraprofunda (deep drawing steels) e produtos revestidos. Essa aciaria caracteriza-se por uma metalurgia sofisticada em todas suas etapas de processo (49), as quais compreendem:

\section{(i) Metalurgia primária}

- Estação de dessulfurizarão de ferro-gusa líquido composta por dois estandes combinados com duas lanças de injeção usando como agente dessulfurizante mistura de cal, carbureto de cálcio e magnésio, capaz a prover um teor final de S no metal de 10 ppm. Remoção de escória por escumação. Todo gusa líquido destinado à aciaria recebe tratamento nessa estação.

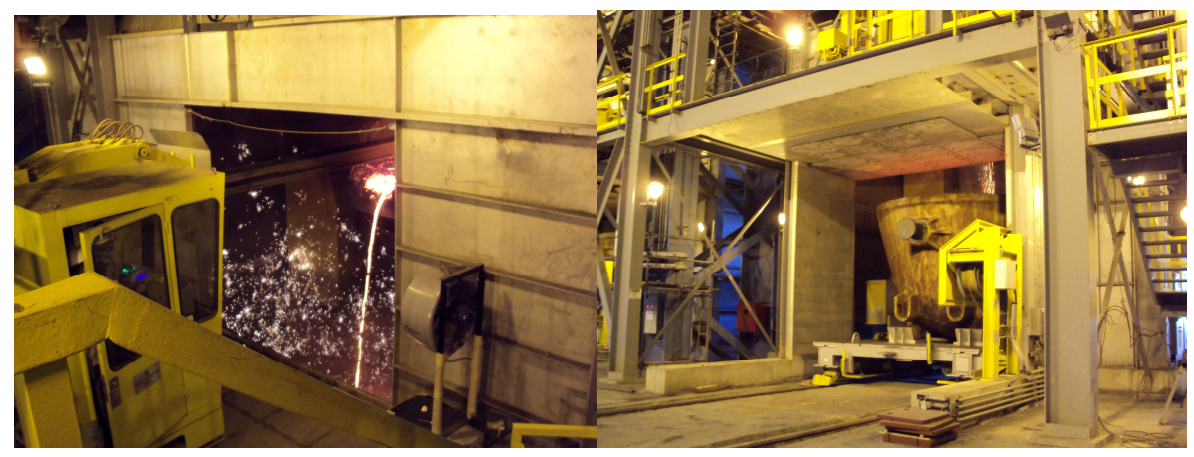

Figura 31- Dessulfurização de ferrro-gusa líquido

- Dois convertedores a oxigênio de capacidade nominal 330t por corrida, volume específico $1 \mathrm{~m}^{3} / \mathrm{t}$, sopro combinado via injeção de argônio, slag free tapping, controle estático e dinâmico de processo por sublança.

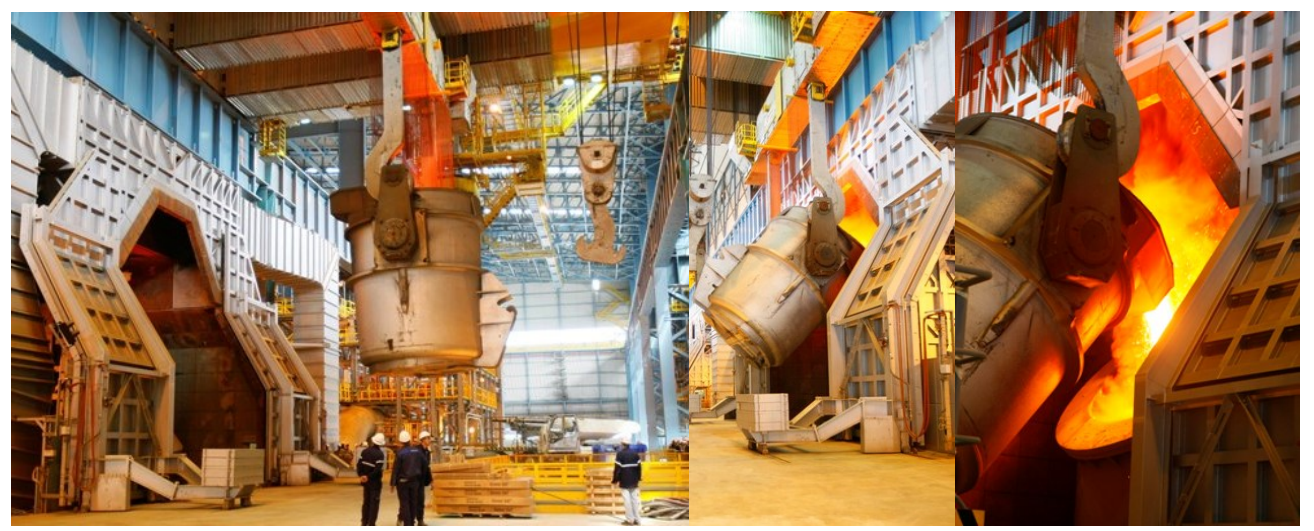

Figura 32- Convertedores a oxigênio

\section{(ii) Metalurgia secundária}

- Duas estação de tratamento de aço líquido na panela de vazamento equipadas cada qual com sistema de lança para injeção de argônio, adição de escória sintética e de alumínio, destinadas a promover a homogeneização da temperatura e composição das corridas após vazamento, determinação do teor de oxigênio e ajustes de temperatura. 


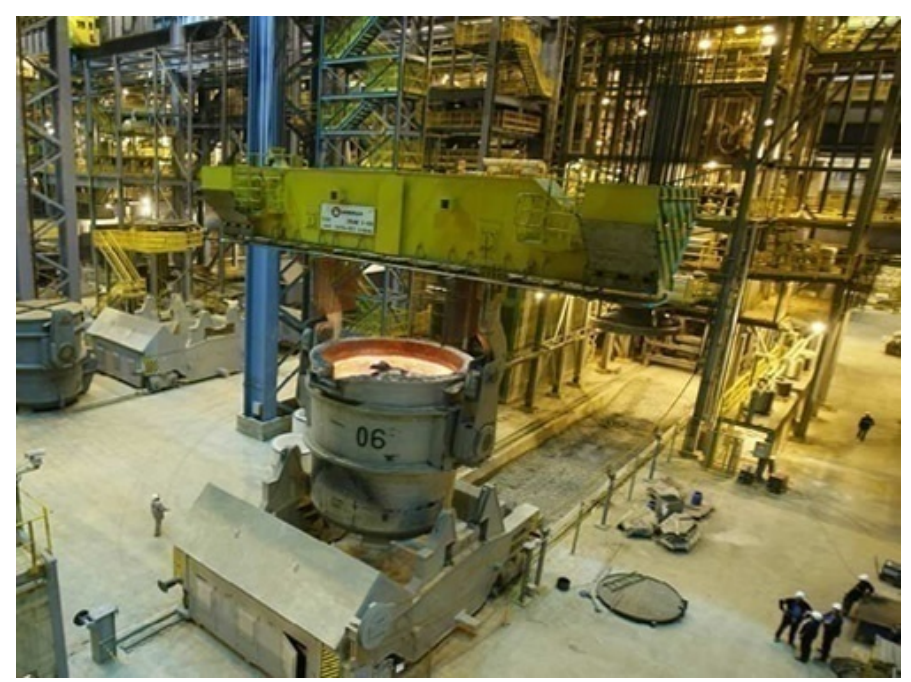

Figura 33 - Panela de vazamento de aço líquido

- Desgaseificação a vácuo tipo recirculativo RH - TOP (Top Oxygen Process, Natural Gas + Oxygen $3^{\circ} \mathrm{C} / \mathrm{min}$ ), gás de arraste argônio, adição de escória sintética, teor final de carbono $<=15 \mathrm{ppm}$, teor final de hidrogênio $<=2,5 \mathrm{ppm}$, tempo de tratamento 15 a $30 \mathrm{~min}$.

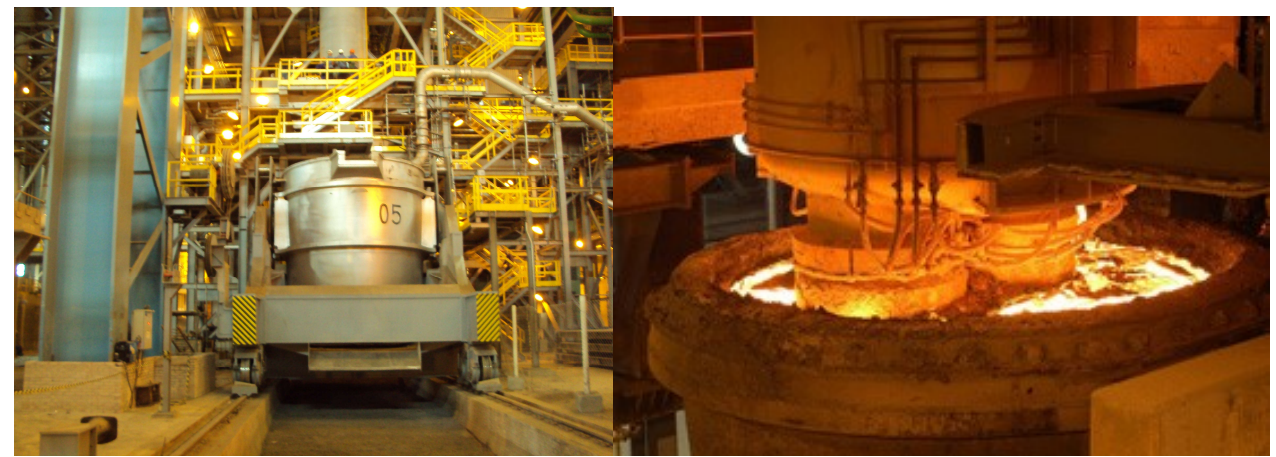

Figura 34 - Desgaseificador a vácuo

- Forno de reaquecimento por alumínio - AHF (Aluminum Heating Furnace) com uma lança de purga com argônio, lança de oxigênio, campânula imersível no banho líquido, dois alimentadores de arames, capacidade de aquecimento $8^{\circ}$ $\mathrm{C} / \mathrm{min}$

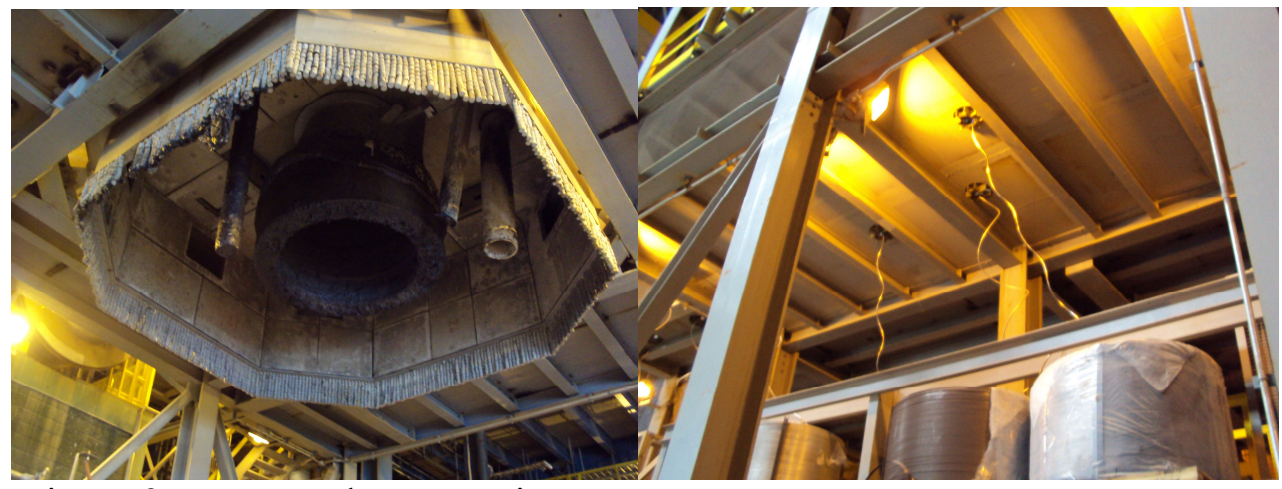

Figura 35 - Forno de reaquecimento RHF 


\section{(iii) Lingotamento contínuo}

As principais características das duas máquinas de lingotamento contínuo que equipam a aciaria são apresentadas em prosseguimento. Essas seguem um perfil dos rolos-suporte com múltiplos raios de lingotamento que cumprem a função de dobramento e endireitamento progressivos de modo a prover uma transição a mais suave possível que minimize os esforços mecânicos associados a estas operações.

Cabe também destacar dois aspectos: o sistema de resfriamento secundário do tipo air mist no qual a água é pulverizada via ar comprimido de modo a promover uma melhor distribuição das condições de resfriamento da superfície das placas em lingotamento e o de lingotamento sob compressão (soft reduction) de modo a promover melhores condições para flotação de inclusões não metálicas (50). A especificação técnica dessas máquinas é em prosseguimento apresentada:

\section{Número \\ Tipo \\ Duas idênticas \\ Dobramento vertical}

Número de veios por máquina

Capacidade mensal

Velocidade de lingotamento

Tempo médio de lingotamento

Corridas por dia

Largura das placas

Comprimento das placas

Espessura das placas

Comprimento do molde

Parte vertical

Raio principal

Comprimento metalúrgico

Capacidade do distribuidor

Câmara de resfriamento

Resfriamento

Lingotamento dinâmico sob compressão
2

$2 \times 208.500 t$

Máx. 1,2 m/ min

$50 \mathrm{~min}$

24 (cada)

$800-2.000 \mathrm{~mm}$

$5.600-12.000 \mathrm{~mm}$

$255 \mathrm{~mm}$

$900 \mathrm{~mm}$

$2.780 \mathrm{~mm}$

$9.000 \mathrm{~mm}$

$29.800 \mathrm{~mm}$

80 t de aço líquido

Tipo túnel

Pulverização a ar (air mist)

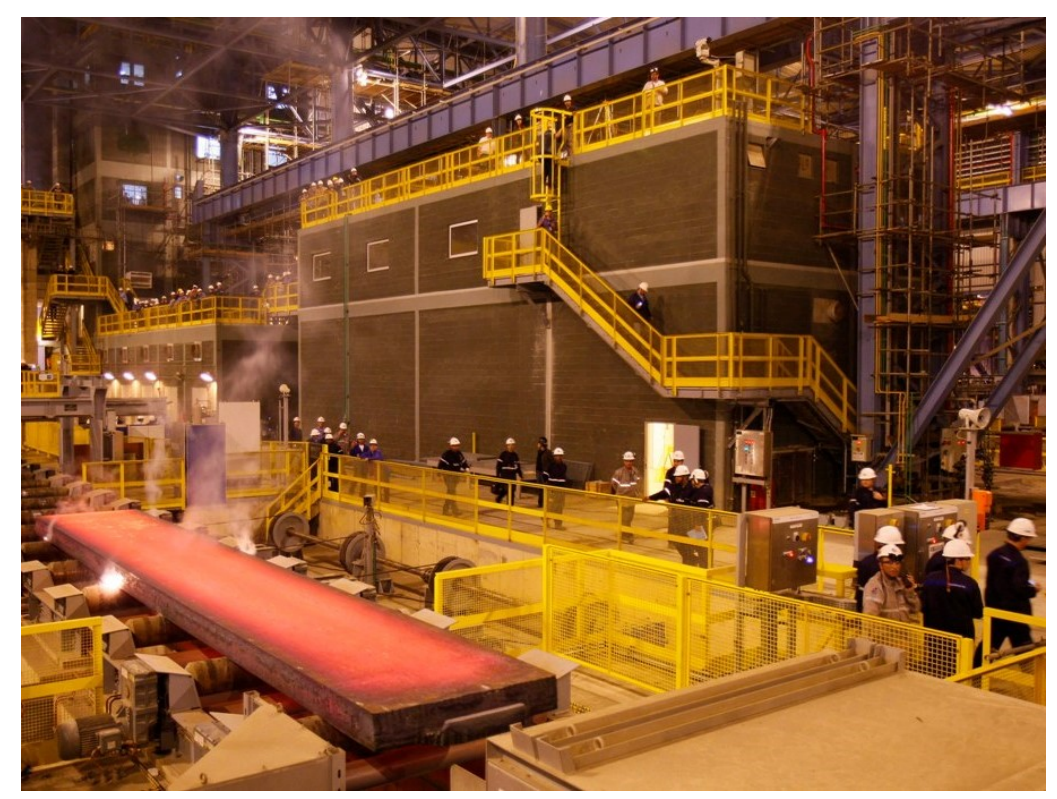

Figura 36 - Lingotamento contínuo 
Todo aço líquido produzido nessa aciaria é submetido a tratamento sob vácuo se o teor de hidrogênio contido ultrapassar $8 \mathrm{ppm}$ de modo a preservar sua lingotabilidade, independentemente se tal é demandado por força de composição química ou exigência de especificação técnica.

O fenômeno de ocorrências de perfurações de veio induzidas por hidrogênio em aços acalmados por alumínio sem rota de desgaseificaçao é amplamente reportado. O hidrogênio é absorvido no banho de metal líquido por absorção de humidade, principalmente em elementos de adições como as ferro-ligas.

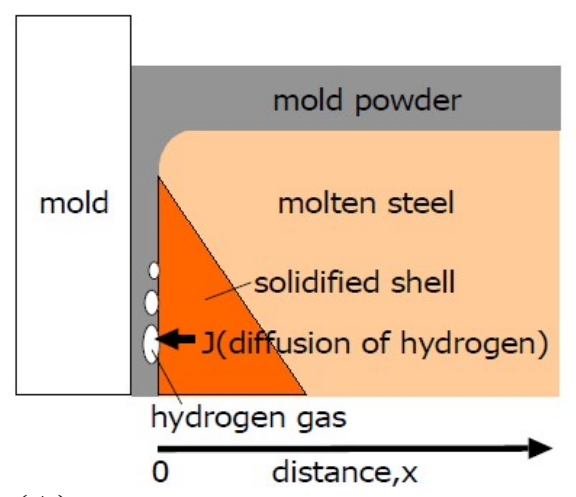

(A)

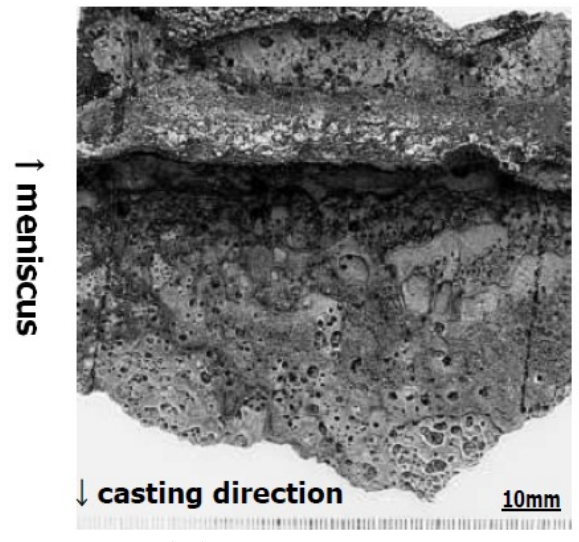

(B)

Figuras 37- Perfurações de veio induzidas por hidrogênio dissolvido (51)

A operação dessas máquinas de lingotamento contínuo é extremamente estável, como testemunhado por técnicos de empresas do setor siderúrgico em inspeções de processo visando a aquisição de placas. A incidência de perfurações de veio é reduzida, inferior à média verificada internacionalmente.

Variações de nível de aço líquido no molde atingem um valor máximo garantido de $+/-7 \mathrm{~mm}$ (52). As placas produzidas não sofrem resfriamento forçado por aspersão de água enquanto em resfriamento. Exceções episódicas são abertas para qualidades menos sensitivas como as de baixo carbono.

(iv) Sistemas integrados de automação, controle, supervisão de processos e de gerenciamento da qualidade

A aciaria e lingotamento contínuo operam de forma integrada sob sistemas de automação, controle, supervisão de processos e de gerenciamento da qualidade em três níveis hierárquicos de arquitetura:

- Nível 1 - automação de processos

- Nível 2 - controle

- Nível 3 - supervisório

O Nível 3 concentra-se no MES - Manufacturing Execution System que se encarrega da emissão dos relatórios de acompanhamento da produção e é integrado parcial e pontualmente ao sistema corporativo ERP (Enterprise Resource Planning). O Nível 2 de controle permite atuação direta nos processos e 
armazena os modelamentos matemáticos e rotinas de fabricação dos diferentes tipos de aços produzidos. Valores de parâmetros de processo são tirados dos convertedores, metalurgia secundária e das maquinas de lingotamento contínuo.

As placas são automática e periodicamente rastreadas em intervalos prédeterminados de comprimento ao longo do sentido de lingotamento e suas condições de qualidade avaliadas em função de parâmetros previamente estabelecidos de processamento. Isso é feito por meio de um algoritmo de controle que gera um código que define a qualidade da placa em função de sua aplicação.

Desvios de processo provocam o downgrade automático do código de qualidade. Tais desvios incluem, por exemplo, desvios da velocidade de lingotamento, alteração no nível do molde e sobreaquecimento do aço líquido em relação aos padrões preconizados.

As placas produzidas são submetidas a inspeção visual enquanto ainda quentes. Se vislumbrados problemas potenciais de qualidade como aços peritéticos ou mais suscetíveis a ocorrências de trincas em virtude dos teores de carbono e/ou conteúdo de ligas, as placas são encaminhadas para a área de acabamento para sofrerem inspeção a frio, que pode ser visual ou por meio de procedimentos de escarfagem de verificação (check-scarfing).

As placas produzidas são fornecidas aptas ao carregamento direto nos fornos de reaquecimento de laminações de tiras a quente sem demandarem qualquer tratamento adicional.

Como rotina, diariamente são retiradas amostras das placas por máquina e veio lingotado para ensaios de macrografia por impressão de enxofre (método Baumann) para verificação da qualidade interna do material como lingotado e a ocorrência de defeitos tais como trincas, porosidades, orifícios, macroinclusões e segregação.

Também de forma rotineira são realizadas inspeções de atendimento aos padrões dimensionais internos ou impostos por terceiros que abrangem tolerâncias de espessura, largura, comprimento, empeno, curvamento, esquadro, conicidade, concavidade, conicidade, abaulamento e desvios de corte.

Todas as operações realizadas por essa aciaria são acompanhadas por retiradas de amostras do aço líquido em processamento, as quais são analisadas pelo laboratório da aciaria em tempo real.

Um exemplo de macrografia de placa $\mathrm{C}-0,0760 \%$ em peso é mostrada na Figura 33. 


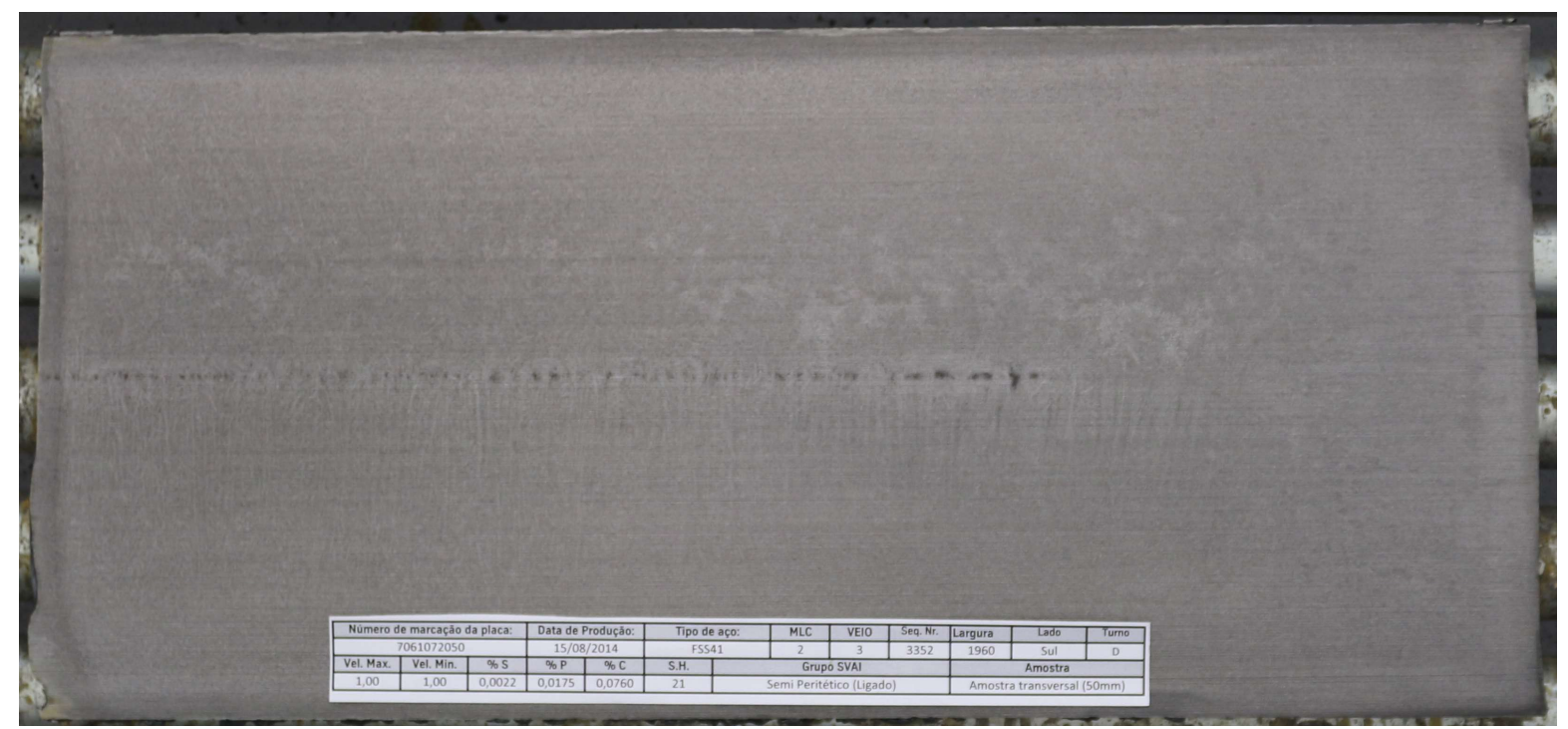

Figura 38 - Macrografia (49)

Sob essa ótica de tarugos continuamente lingotados e os obtidos via cortes longitudinais de placas, cabe, entretanto, observar as diferenças entre suas respectivas estruturas internas como mostradas na Figura 39.

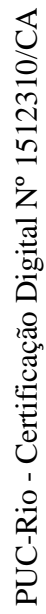

Tarugos conformados por oxicorte não detêm as mesmas estruturas internas que aqueles, apenas supondo a realização de cortes em uma placa de aço.

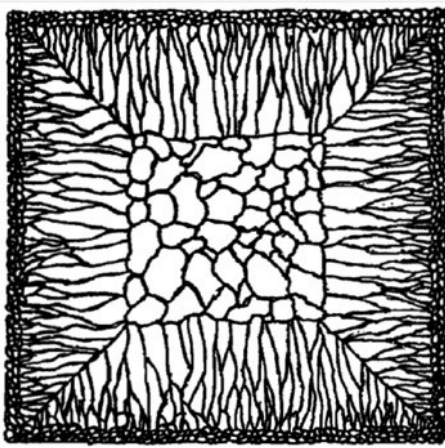

(A)
$130 \mathrm{~mm}$

r

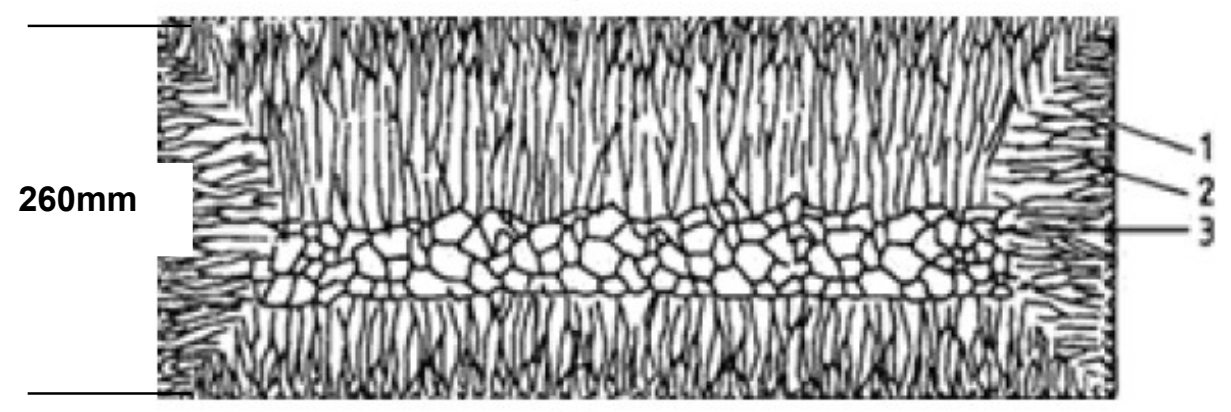

$\mathrm{R}$

(B)

Figura 39 - Estururas internas de tarugos (A) x placas de aço (B) $(53,54)$ 


\subsubsection{Defeitos de laminação}

Essas empresas laminadoras podem ter como matérias-primas tarugos ou placas de aço de lingotamento contínuo.

A despeito de as placas demandarem operações adicionais de corte e consequentemente alguma perda de rendimento de material oriunda destas operações de corte, a aquisição de placas demonstra-se vantajosa para essas empresas à medida que:

- Os produtores de tarugos são usualmente usinas siderúrgicas semi-integradas que operam aciarias elétricas à base de sucatas ferrosas, fundamentalmente os recicladores.

Os semiacabados produzidos por essas são preferencialmente destinados às suas próprias instalações de laminação de produtos longos e não à venda para terceiros.

- As usinas integradas produtoras de placas de aço, especialmente as que se dedicam à produção e venda desses semiacabados para terceiros ou encontram excedentes na respectivas produções de placas, são concebidas para encontrar suas economicidades de processo em elevadas escalas de produção.

Essa aposta nas elevadas escalas de produção como denominador na redução dos custos de produção aplica-se à usina em pauta produtora das placas SAE 1020 das quais se originaram os defeitos de laminação a quente.

Três corridas sequenciadas de $330 \mathrm{t}$ de aço no lingotamento contínuo resultam por volta de $1.000 \mathrm{t}$ de placas. Se o produtor independente demanda, por exemplo, placas de $25 \mathrm{t}$, esta tonelagem resulta em 40 placas ou quase 550 tarugos de $1.800 \mathrm{~kg}$ cada.

- Nessas usinas integradas que partem do minério de ferro como principal matéria-prima, os laminadores independentes encontram produtos que seguem o moderno conceito de clean steel, assim denominados os aços nos quais os conteúdos de impurezas como fósforo, enxofre, oxigênio total, nitrogênio e inclusões em geral é muito baixo.

As usinas recicladoras de sucatas ferrosas, por sua vez, não conseguem atender a tais requisitos de clean steel em virtude das próprias características desta matéria-prima naturalmente contaminada.

Cabe notar que as ditas impurezas variam de acordo com os tipos de aços produzidos, à medida que os elementos de controle são diferentes dependendo do tipo de aço (55).

Mas, a despeito de toda essa infraestrutura de processamento e qualidade operacional, ocorreu sistematicamente em distintos laminadores e diversas corridas de aço uma série catastrófica de severos defeitos de laminação a quente a 
partir de tarugos provenientes de placas de aço SAE 1020, como mostrada na Figura 40. Esses defeitos causaram perdas totais do produto em laminação e de produção devidas a interrupções no processamento do material.
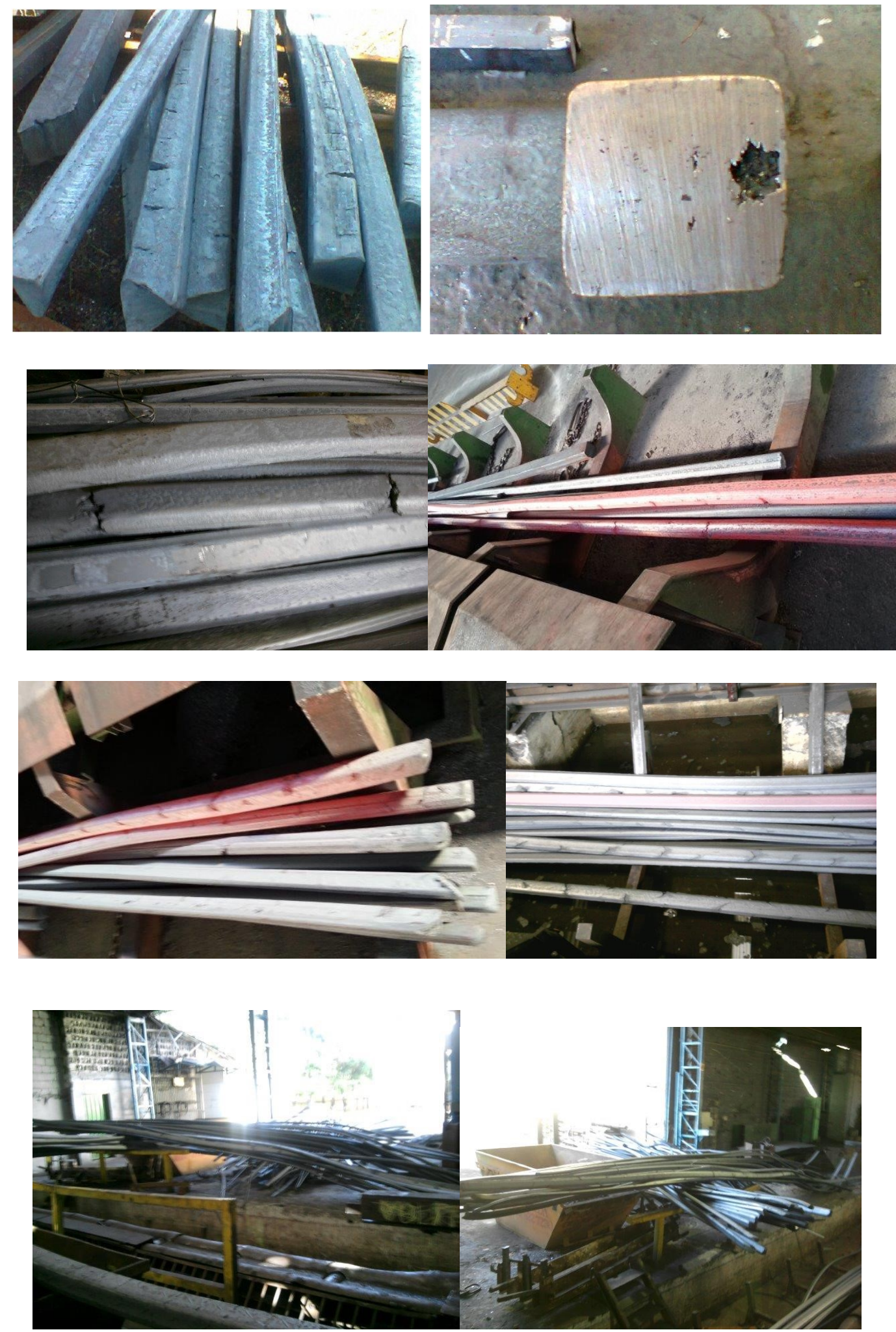

Figura 40 - Série de eventos de defeitos em laminados a quente de aço SAE 1020 $(42,48,56)$ 
As ocorrências de trincas nas placas constituíram fato inequívoco como reportado pelas empresas laminadoras e mostradas nos exemplos da Figura 25. Dessas trincas resultaram os defeitos de laminação. Entretanto, os resultados da análise realizada por uma dessas empresas e reproduzidos na Figura 41 anterior indicam defeitos localizados apenas nas linhas de corte (defects located only in the cutting line).

Aventou-se a hipótese que as trincas podem ter se originado em microtrincas formadas em regiões de baixa ductilidade do material enquanto em lingotamento, como em contornos grãos como mostrado na Figura 15, e exacerbadas pelo fenômeno de contração adicional devida a transformações peritéticas como anteriormente exposto.

Já pré-existentes ou latentes no interior das placas, essas microtrincas podem ter sido intensificadas e propagadas pela ação conjugada dos seguintes mecanismos:

(i) Esforços mecânicos introduzidos no material por sua própria expansão natural provocada por seu aquecimento durante as operações de oxicorte e contração em seu posterior resfriamento de volta à temperatura ambiente.

O material ainda sofre um segundo ciclo de aquecimento no forno de reaquecimento do laminador.

(ii) Pelo surgimento nesse processo de fases de maior dureza, e consequentemente menos dúcteis como a martensita, devido à formação de zonas termicamente afetadas como exemplificado na Figura 42.

Como antes mencionado, Figura 30, as placas eram cortadas a quente pela empresa laminadora com o emprego de maçaricos, o que poderia resultar em uma região que recebia um elevado aporte térmico de modo a produzir uma fusão localizada no material. $\mathrm{O}$ autor desta dissertação optou por empregar a denominação de zona termicamente afetada para essa região, Figura 37 (A).

Um estudo abrangente sobre as chamadas zonas térmicas afetadas provocadas por operações de cortes térmicos é encontrada na referência (57).

A zona termicamente afetada por operação de corte a quente consiste em uma das duas séries de estruturas mostradas nas Figura 42 (B) dependendo se a operação de corte foi realizada ou não sem pré-aquecimento. 

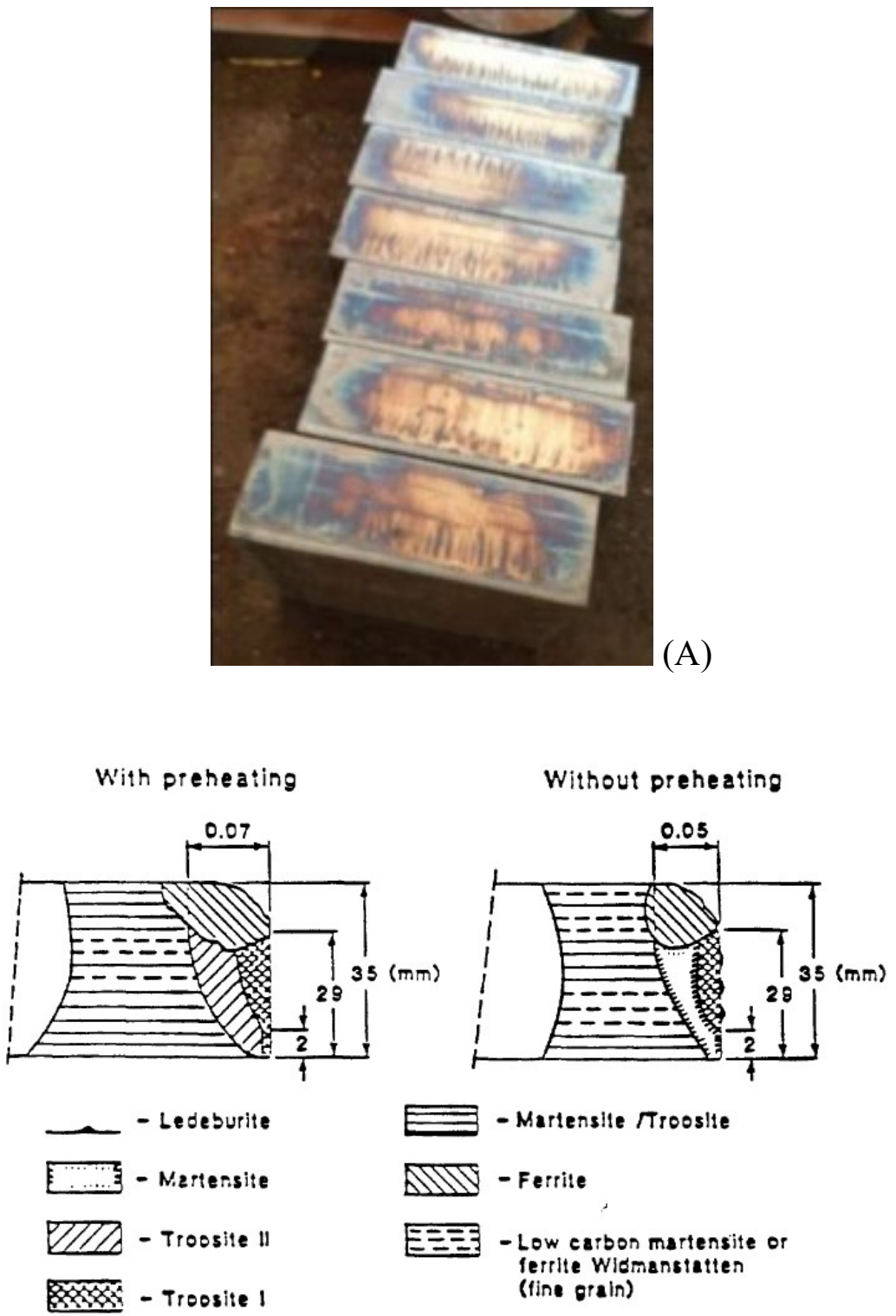

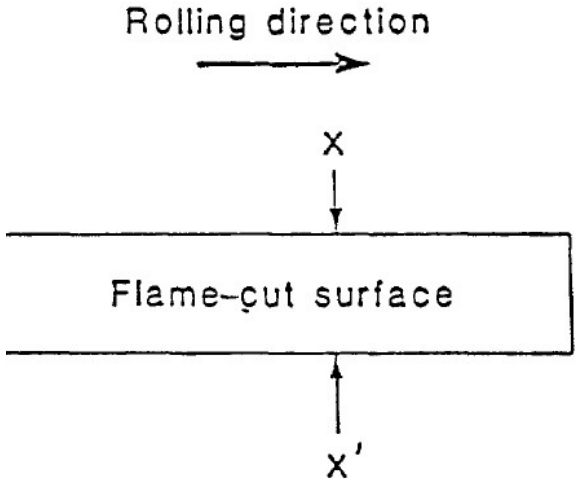

(a)

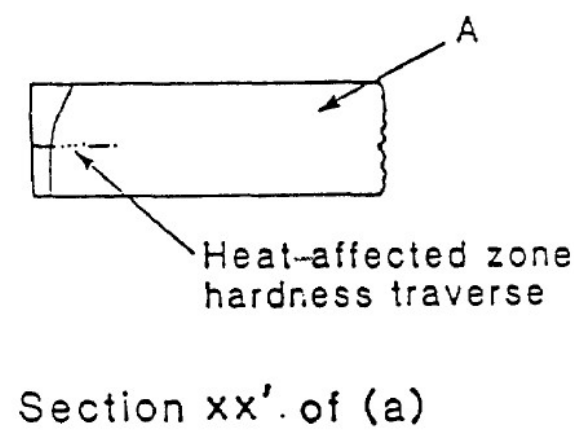

(b)

(C)

Figura 42 - Zonas termicamente afetadas

Ledeburita - eutético em ferro fundido que contém $95,7 \%$ de ferro e $4,3 \%$ de carbono Troostita - perlita fina 
Esse aspecto sempre lembrado e considerado de promoção de pré-aquecimento do material a ser submetido a elevadas temperaturas com o propósito de suavização dos efeitos decorrentes da ação térmica foi tentado por um dos laminadores independentes por meio de um maçarico de aquecimento.

Em inspeção de campo, essa intenção de aportar pré-aquecimento ao material a ser cortado demonstrava-se uma operação infrutífera. O ferro não é um bom condutor de calor e são placas com $260 \mathrm{~mm}$ de espessura. A operação visivelmente provocava mais danos à superfície do material do que benefícios porventura decorrentes (42).

A Figura 43 exibe uma severa ocorrência de trinca superficial em uma placa de aço 1045 submetida a operações de oxicorte.

Essa trinca emergiu posteriormente no material à medida que placas em uma condição como essa não seriam despachadas para posterior processamento.

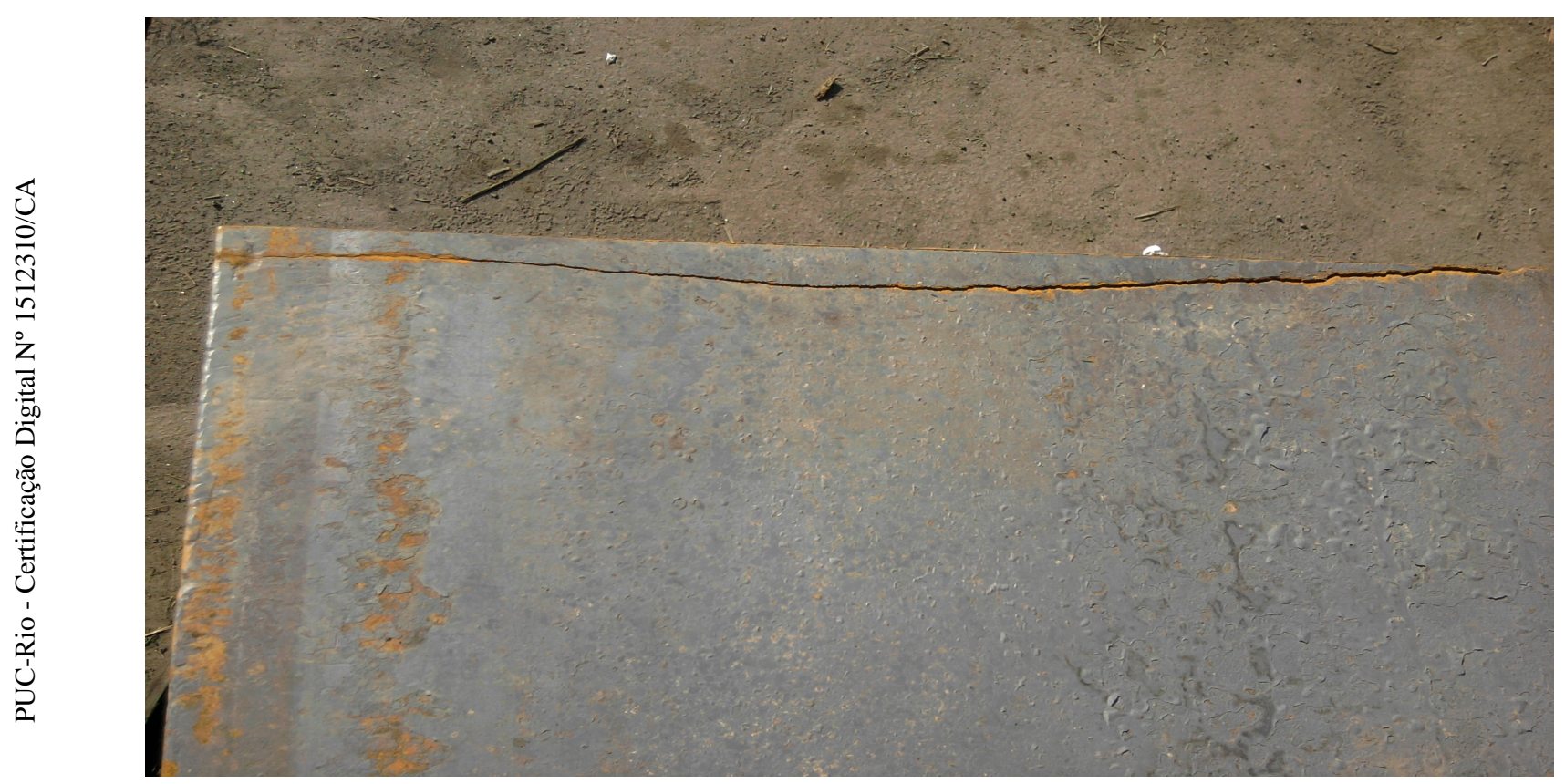

Figura 43 - Trinca superficial em placa de aço 1045 (41)

Pertinente igualmente observar os resultados apontados por relatório técnico de um dos laminadores (56) de análise de composição química e microinclusões, assim reproduzidos: 
"Executamos análise de composição química e microinclusões, cujos resultados indicam normalidade química e de inclusões".

"Conclusão: material reprovado decorrente da abertura de vazios intermitentes ao longo da barra durante os 4 primeiros passes de laminação a quente."

\section{“Conclusão final:}

$1^{0}$ - Baseado nos laudos de ensaios, os defeitos detectados durante a laminação não estão relacionados a microinclusões não metálicas.

$2^{\circ}$ - Baseado na observação de performance dos tarugos do centro da placa, os defeitos não estão relacionados à região central da placa."

Esses resultados vêm a corroborar a excelência das placas produzidas sob o aspecto de incidência de inclusões não metálicas como mostrado nas Figuras 36 e 41.

Essa "abertura de vazios intermitentes ao longo da barra" são as mostradas nas duas primeiras imagens da Figura 40.

\subsection{Proposição de outra composição química (aço substituição)}

Alguma solução deveria ser encontrada e testada com o propósito de superar os problemas de defeitos de laminação encontrados de modo a assegurar a continuidade do fornecimento de placas para essas empresas.

Afastadas possíveis falhas de processamento como causa dos defeitos ocorridos, a alternativa considerada foi a de desenvolvimento de um novo tipo de aço que substituísse o clássico SAE 1020 empregado.

A lógica de projeto desse novo tipo de aço fundamentar-se-ia na redução do teor de carbono à medida que benéfica em condições de transformações peritéticas, como mostrado na Figura 10 e explicitado na página 20, e por sua notória influência como elemento endurecedor da martensita, Figura 44.

A redução do teor de carbono também traria relevante contribuição adicional na minimização dos reflexos sobre a ductilidade do material advindos de zonas termicamente afetadas durante as operações de corte das placas. 


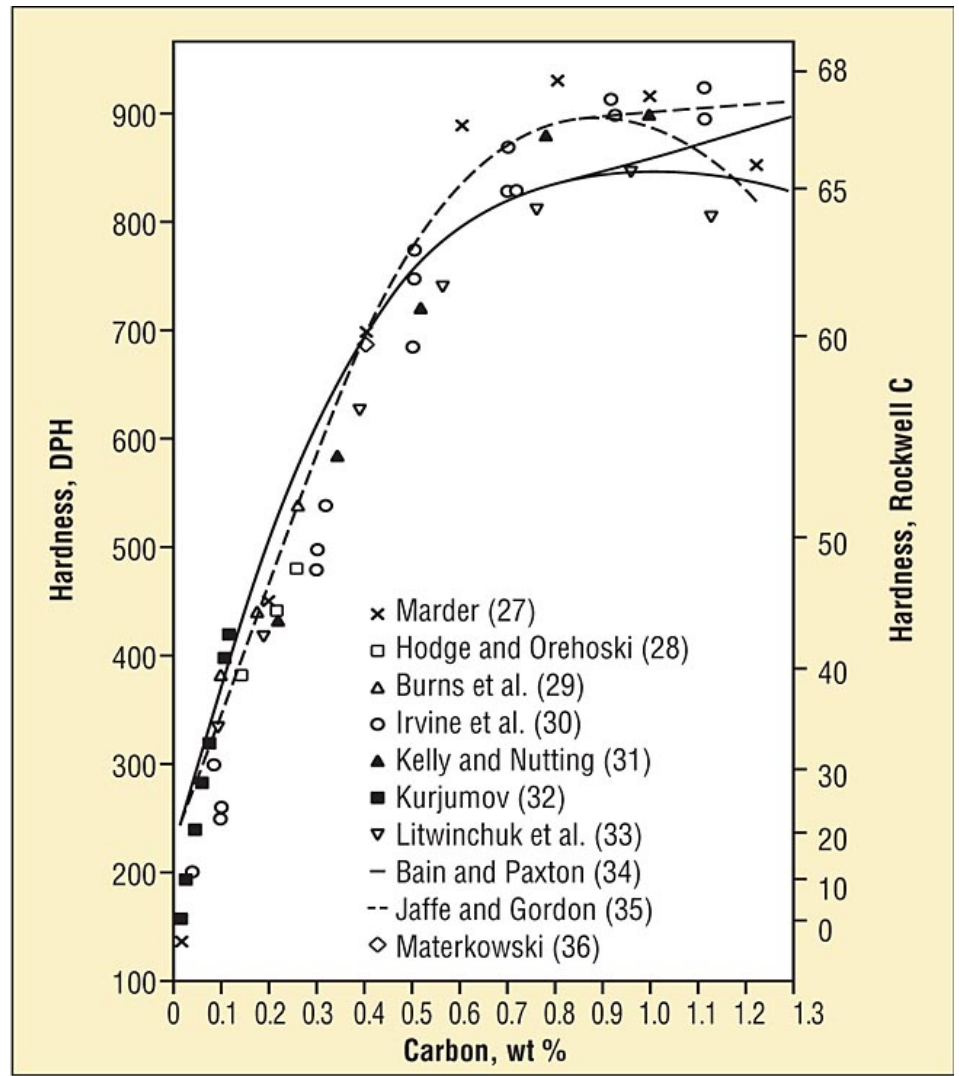

Figura 44 - Influência do teor de carbono na dureza da martensita $(58,59)$

Duas alternativas nesse sentido foram apresentadas e discutidas com uma dessas empresas laminadoras (41):

(i) Um aço de baixo carbono microligado ao nióbio na faixa de 0,08 a $0,13 \%$ C em peso

Aços microligados de alta resistência e baixa liga (HSLA) caracterizam-se por sua resistência a trincas. O nióbio é um elemento de excelente custo/benefício encontrável aqui no Brasil e pioneiro nos processos de refino de grão por dispersão de partículas que agem como agentes inibidores do crescimento dos grãos da austenita.

Uma estrutura de grãos finos permite uma significativa melhoria nas propriedades mecânicas e resistência ao trincamento dos aços (60).

(ii) Um aumento no teor de manganês seguido de um decréscimo no teor de carbono C- $0,11 \%$ a $0,14 \%$ em peso e $\mathrm{Mn}-0,60 \%$ a $0,90 \%$ em peso

Essa alternativa fundamentar-se-ia na substituição de parte do carbono em solução sólida intersticial pelo manganês em solução substitucional. 
As relações $\mathrm{Mn} / \mathrm{C}$ foram inferidas a partir de dados disponíveis na literatura especializada como na abrangente referência (61), a qual sumariza os efeitos mutuamente dependentes de ambos os elementos sobre o limite de resistência das ligas relativas a adições de $\mathrm{Mn}$ em peso e que a ductilidade resultante foi pouco afetada.

Tecnicamente, a primeira hipótese parecia a mais indicada à medida que essa se enquadrava na categoria dos aços de baixos teores de carbono como o SAE 1010, conhecidos como aços doces.

Esses tipos de aços de baixos teores de carbono são genericamente assim denominados por suas reconhecidas propriedades de ductilidade e estampabilidade. Suas faixas de tolerâncias de teores de carbono os tornam afastados do patamar peritético de $0,17-0,18 \% \mathrm{C}$ em peso (Figura 10), como ocorre no SAE 1020 clássico com $0,18-0,23 \%$ C em peso. Nenhum problema de qualidade foi reportado para placas de aço $1010 \mathrm{em}$ embarques deste material para empresas laminadoras.

A opção selecionada pela empresa laminadora para testes foi a segunda. Placas foram então produzidas segundo essa especificação sob a forma de um lote de teste, que é um procedimento usual no mercado de placas de aços. Foram cortadas sob a forma de tarugos e laminadas sem que apresentassem quaisquer problemas. Ensaios mecânicos realizados pela empresa relaminadora no material laminado comprovaram que este atendia às características mecânicas demandadas.

Essa nova composição química passou daí para frente a integrar a especificação técnica de aquisição de placas dessa empresa (62).

Um segundo lote seguindo essa nova composição química foi posteriormente enviado para testes a outra empresa laminadora envolvida nos defeitos de laminação apontados, os quais foram igualmente bem-sucedidos. E também passou a constar de sua especificação técnica para aquisição de placas (63).

Desde então toda a produção de aço SAE 1020 por parte da empresa produtora dessas placas foi integralmente substituída por esse novo tipo de aço, batizado como pseudo-1020. Questões de qualidade como essas ocorrências não foram mais reportadas.

O manganês encontra-se presente na maioria dos aços comerciais. Além do aumento da resistência mecânica oferecido por sua presença, esse elemento exerce mais dois relevantes papeis, nomeadamente sua habilidade em combinar com o enxofre e sua capacidade como agente desoxidante notadamente na presença conjugada com o silício.

Esse aumento do teor em manganês em detrimento do carbono fez com que a relação $\mathrm{Mn} / \mathrm{S}$ fosse do mesmo modo proporcionalmente incrementada, trazendo assim um benefício adicional na prevenção de ocorrências de trincas como exposto na página 28. 


\section{Procedimento experimental}

Duas amostras dos materiais envolvidos nesta dissertação, o SAE 1020 clássico e o de substituição proposto, foram cedidas pela empresa laminadora CIAFAL com o objetivo de serem realizados ensaios mecânicos. Essas amostras, oriundas do laminador desbastador dessa empresa, são apresentadas nas Figuras 45 e 46.

As duas primeiras, Figura 45, correspondem ao SAE 1020 clássico. A segunda corresponde ao aço de substituição, Figura 46.

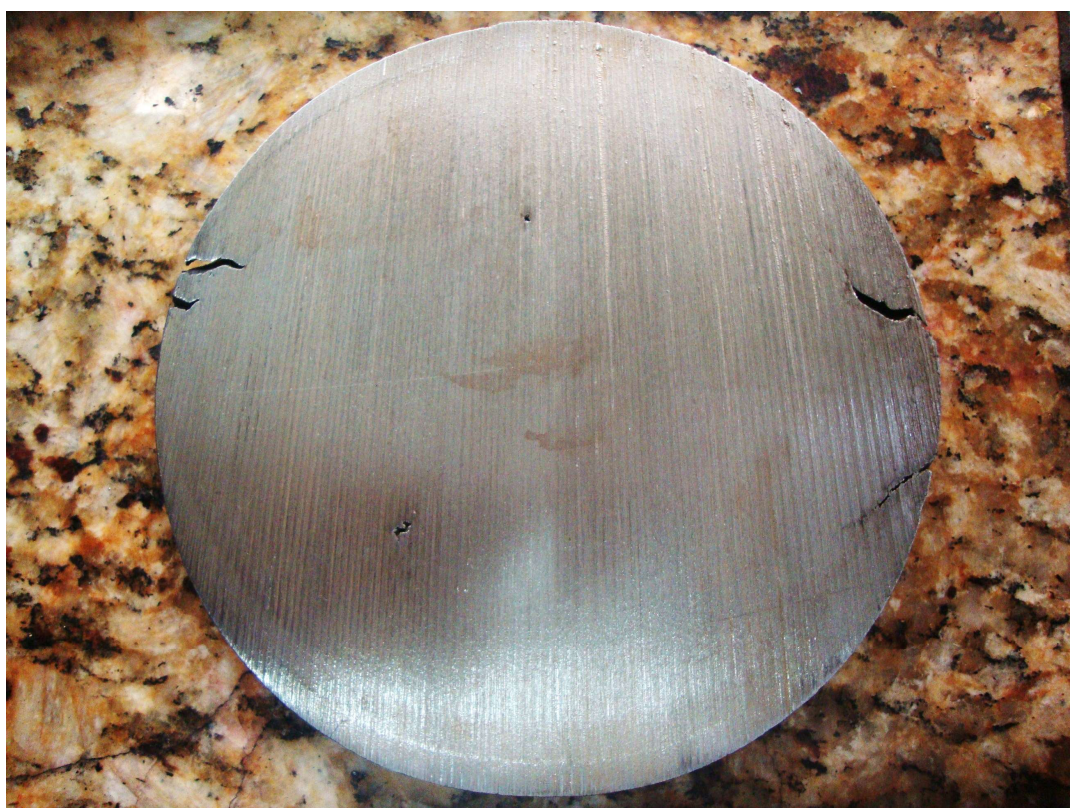

(A)

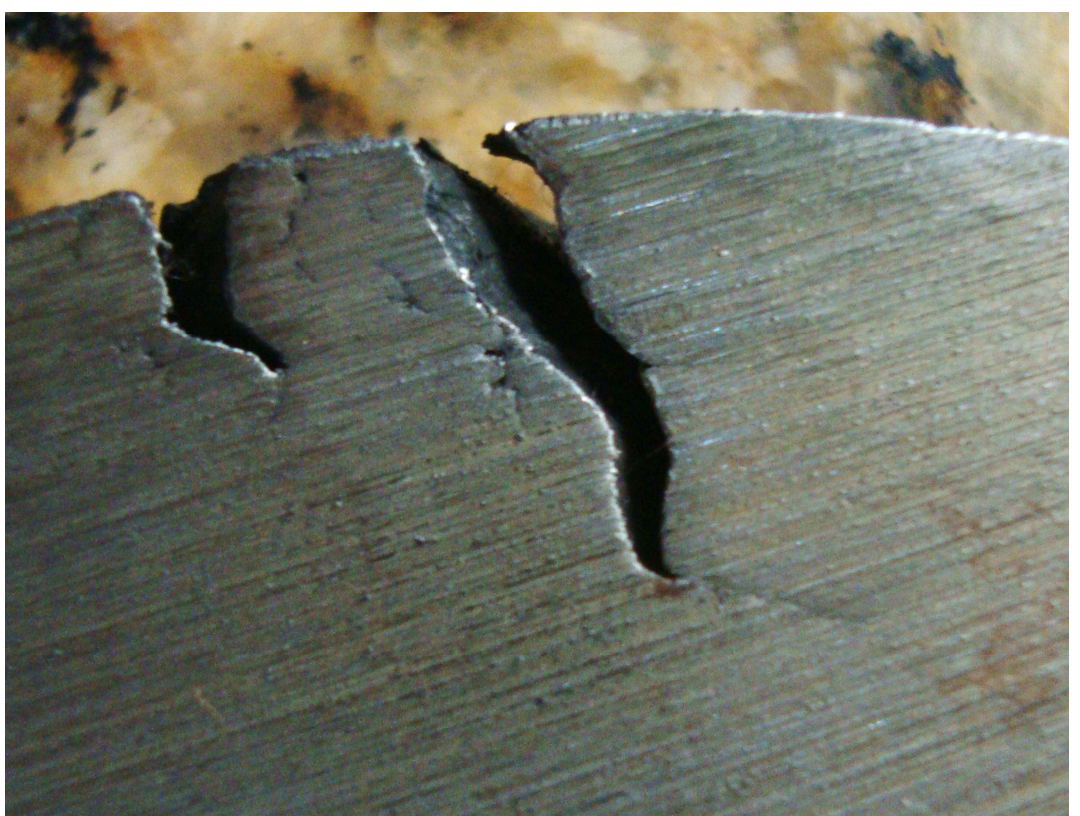

(B)

Figura 45 - Amostra de aço SAE 1020 exibindo trincas de laminação, detalhe em (B) 


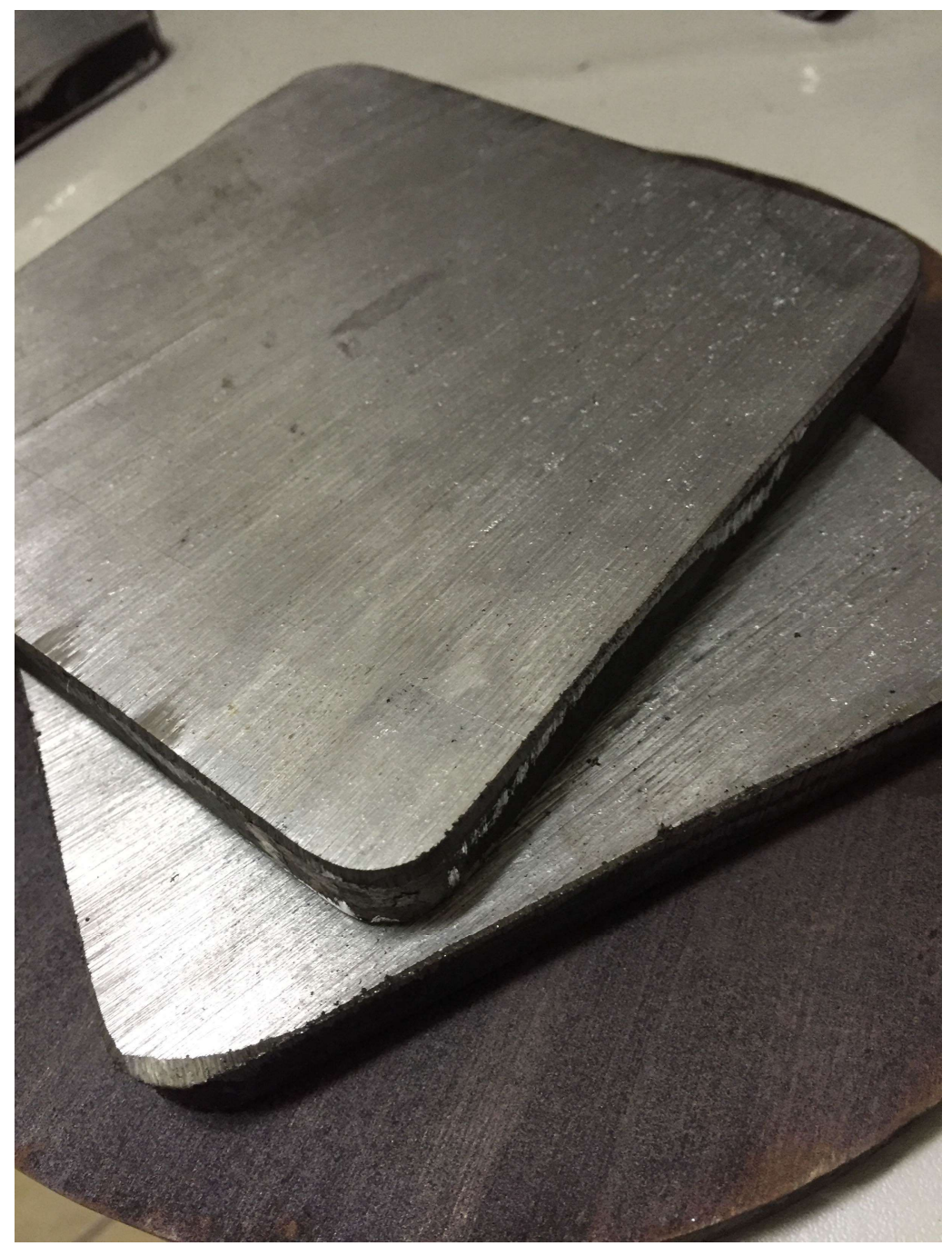

Figura 46 - Amostra do aço de substituição

Foram realizadas análises químicas nessas amostras dos dois materiais em pauta, bem como ensaios macrográficos em placas do aço de substituição, Figura 48 (42). Em sequência, foram usinados corpos de prova para ensaios de tração, dureza e impacto Charpy. Os corpos de prova foram usinados com seus eixos longitudinais na direção transversal ao sentido de laminação das barras. Optou-se por essa posição pelo fato que as trincas observadas eram transversais ao sentido de laminação.

A Figura 47 mostra os corpos de prova usinados. A primeira imagem (A) refere-se a corpos de prova oriundos da amostra mostrada na Figura 45 (barra cilíndrica). A segunda imagem (B) corresponde à amostra do aço de substituição, Figura 46 (barra quadrada). 
Ao todo foram produzidos dezoito corpos de prova, sendo seis para ensaios de tração, dois para dureza e dez para impacto.

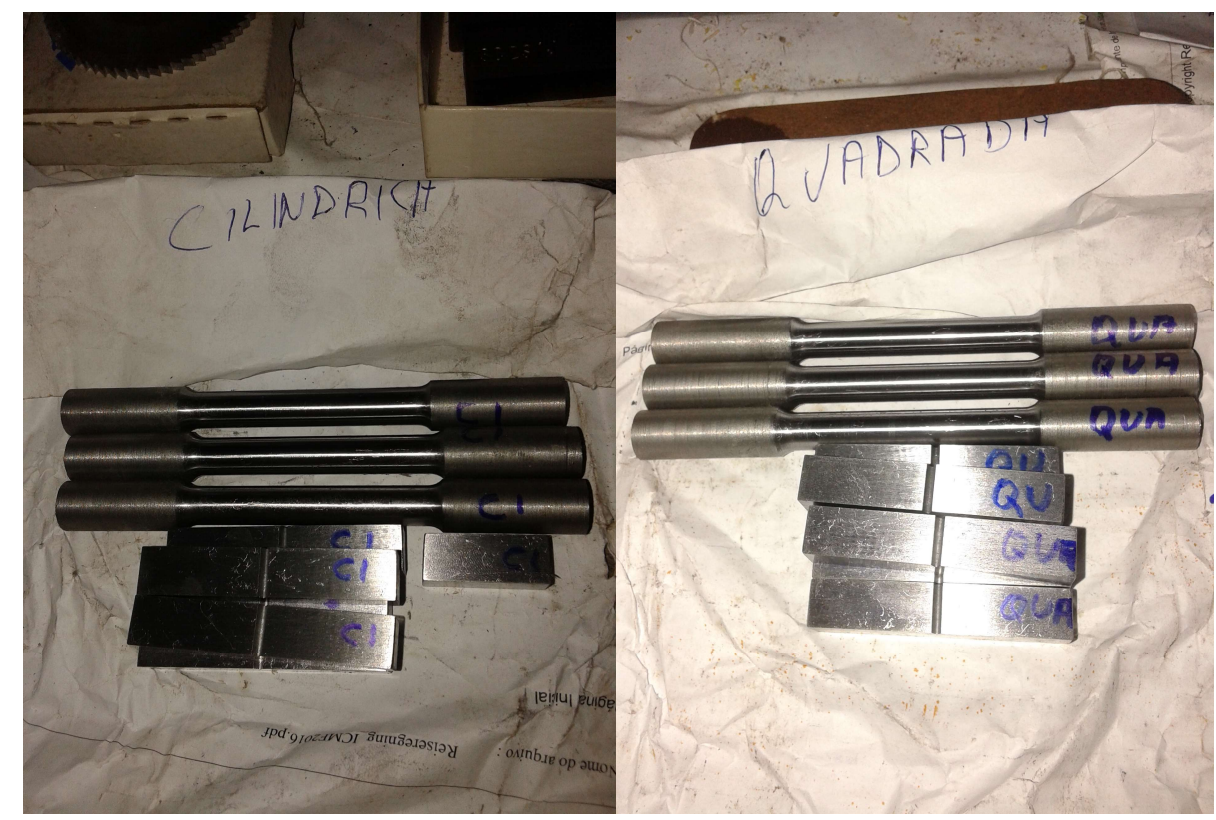

(A)

(B)

Figura 47 - Corpos de prova (A) amostra cilíndrica (SAE 1020 clássico); (B) amostra quadrada (aço de substituição)

Os ensaios foram realizados no Laboratório de Ensaios Mecânicos da PUC - Rio.

Os ensaios de tração, realizados em uma máquina AMSLER de capacidade de carga $100 \mathrm{t}$ de acordo com a norma ASTM A370-16, tinham como objetivo determinar o limite de escoamento, limite de resistência mecânica, alongamento e redução de área no momento da fratura.

Os ensaios de dureza em uma máquina WOLPERT, de acordo com a norma ASTM E18-16.

Para os ensaios de impacto, realizados com o objetivo de se avaliar a tenacidade dos materiais, foi utilizada uma máquina INSTRON modelo SI-1C3 de acordo com a norma ASTM E23-16b. 


\section{Resultados e discussão}

Na Figura 45, a qual mostra a amostra do aço SAE 1020 clássico, são observadas nítidas evidências de incidências de trincas neste material. Já a amostra do aço de substituição, Figura 46, demonstra sua sanidade interna com total ausência de trincas.

Com base na análise nessa amostra, pode-se afirmar que a proposta de uma nova composição química resultou na superação dos problemas de trincas.

\section{(i) Composição química}

As composições químicas do SAE 1020 clássico e do aço de nova composição química de substituição são em prosseguimento apresentadas, respectivamente, em \% de peso:

\section{SAE 1020}

$\begin{array}{ccccc}\mathbf{C} & \mathrm{Mn} & \mathrm{Si} & \mathbf{P} & \mathrm{S} \\ \mathbf{0 , 2 0} & \mathbf{0 , 4 5} & \mathbf{0 , 1 9} & \mathbf{0 , 0 1 7} & (*)\end{array}$

\section{Aço de substituição}

$\begin{array}{ccccc}C & \text { Mn } & \text { Si } & \text { P } & \text { S } \\ \mathbf{0 , 1 3} & \mathbf{0 , 8 6} & \mathbf{0 , 2 0} & \mathbf{0 , 0 1 5} & (*)\end{array}$

(*) Inferior a $40 \mathrm{ppm}$

(ii) Macrografias

A Figura 43 mostra parte de uma série de macrografias em diferentes posições de uma placa desse aço de substituição, obtidas durante o lote de testes de embarque deste material para uma empresa laminadora (42), \%C - 0,1570 em peso. Data de produção 18.05.2014, largura $1.830 \mathrm{~mm}$.

Essas macrografias relevam a qualidade interna, superficial e geométrica das placas processadas pela empresa siderúrgica responsável por sua produção.

Apenas ligeiras marcas de inevitáveis segregações internas podem ser notadas em uma dessas imagens. Cabe ressaltar a ausência de marcas visíveis de oscilação. 

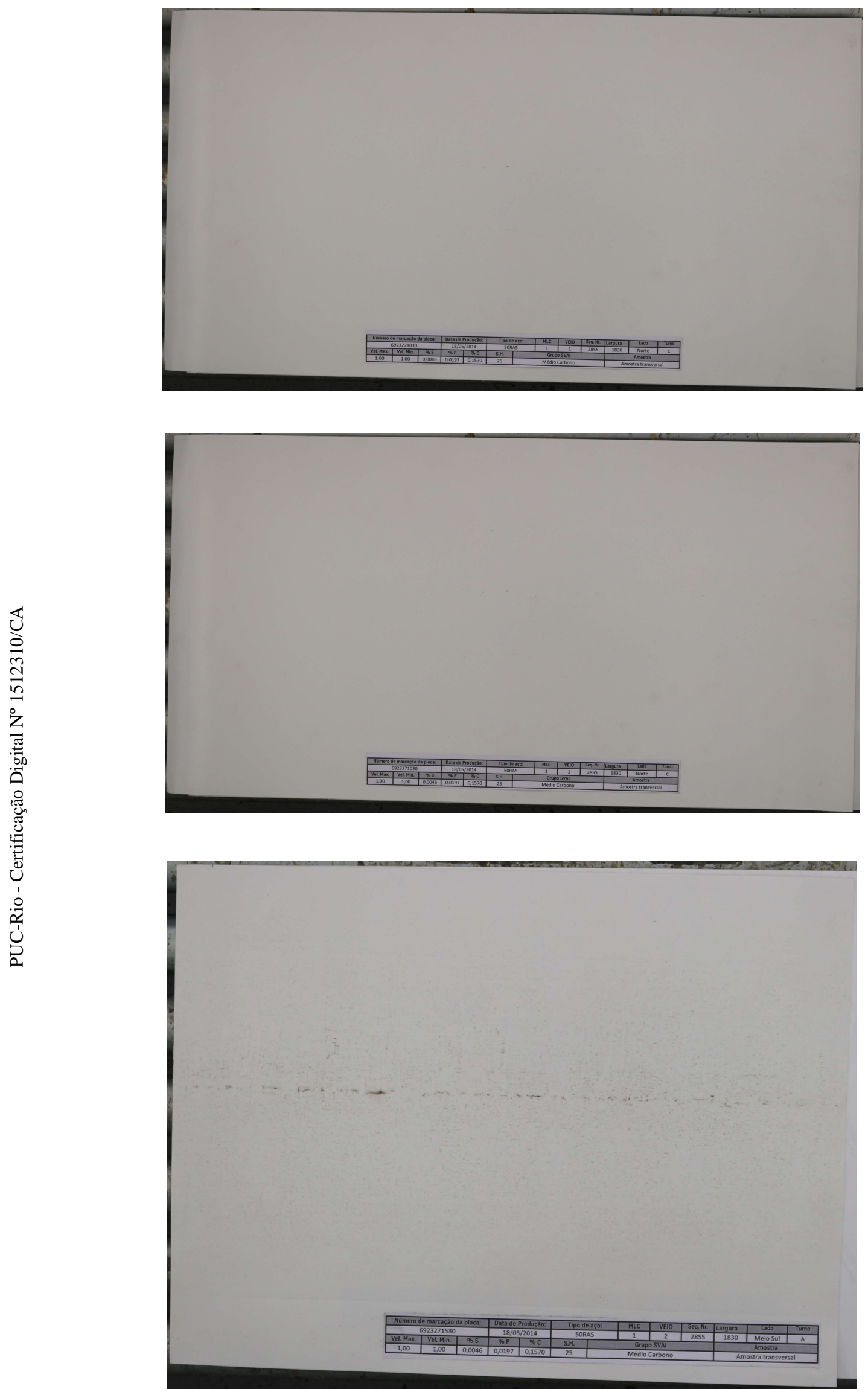

Figura 48 - Série de macrografias 
(iii) Ensaios de tração

Os resultados dos ensaios de tração são a seguir apresentados para as amostras do SAE 1020 clássico (barra cilíndrica) e o aço de substituição (barra quadrada), respectivamente. LE, LR, A e RA significam limite de escoamento, limite de resistência, alongamento e redução de área. Corpos de prova mostrados na Figura 47:
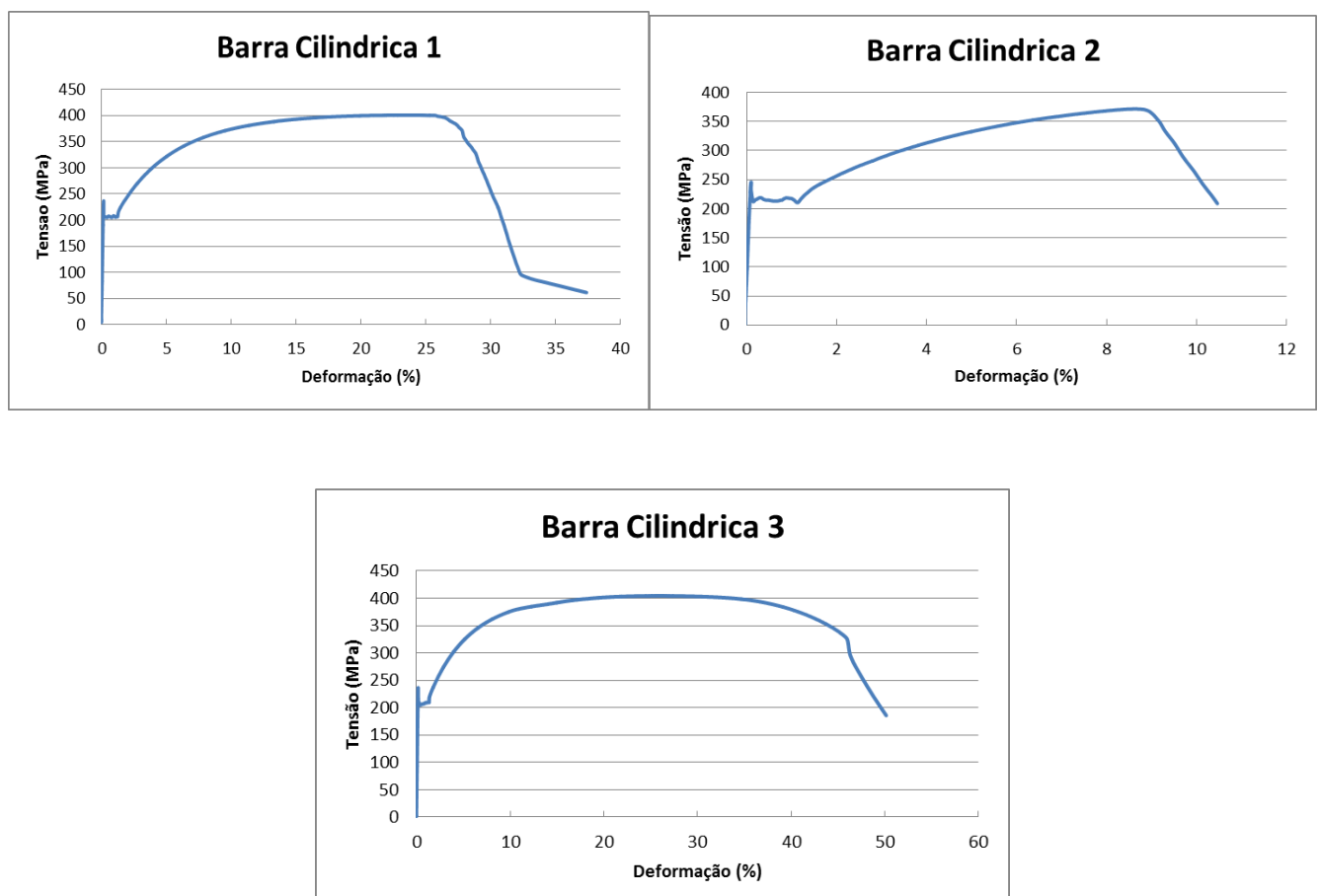

Propriedades mecânicas do SAE 1020 clássico (corpos de prova da Figura 47A)

$\begin{array}{ccccc}\text { CP } & \text { LE (MPa) } & \text { LR (MPa) } & \text { A }(\%) & \text { RA }(\%) \\ 1 & 205,0 & 400,8 & 26,0 & 27,6 \\ 2 & 214,0 & 371,3 & 10,0 & 11,0 \\ 3 & 205,9 & 405,5 & 31,0 & 43,2 \\ \text { Média } & 208,3 & 392,5 & 22,3 & 27,2\end{array}$



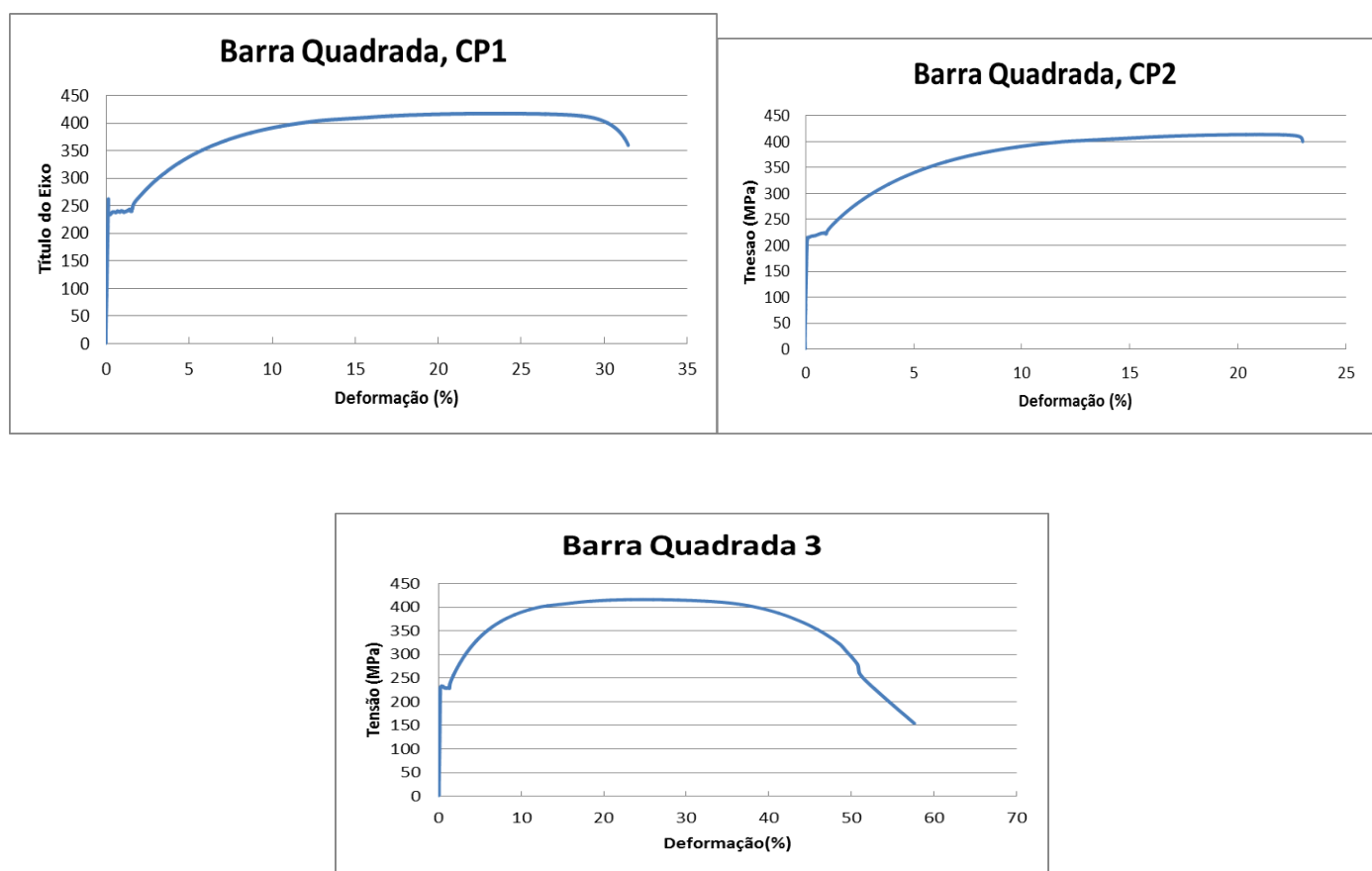

Propriedades mecânicas do aço de substituição (corpos de prova da Figura 47B)

$\begin{array}{ccccc}\text { CP } & \text { LE (MPa) } & \text { LR (MPa) } & \text { A }(\%) & \text { RA }(\%) \\ 1 & 239,0 & 417,5 & 36,6 & 54,3 \\ 2 & 224,0 & 413,8 & 37,2 & 54,6 \\ 3 & 232,0 & 416,5 & 37,6 & 56,5 \\ \text { Média } & 231,6 & 415,9 & 37,1 & 55,1\end{array}$

Como pode ser observado pelos valores médios, há relevante melhoria nas propriedades do aço de substituição comparativamente ao SAE 1020 clássico sob os aspectos de LE, LR, alongamento e redução de área. Ou seja, o aço de substituição apresenta superiores características de ductilidade.

\section{(iv) Ensaios de dureza}

Os resultados dos ensaios de dureza são em prosseguimento reproduzidos. Foi utilizado o método Vickers com carga de 5 kgf (HV5) com medições em três corpos de prova de cada grupo com quatro medições em cada corpo de prova, totalizando doze medições em cada grupo: 
Aço SAE 1020 clássico (barra cilíndrica)

$\begin{array}{rrrrr}\text { CP1 } & 132 & 133 & 137 & 151 \\ \text { CP2 } & 149 & 155 & 147 & 149 \\ \text { CP3 } & 153 & 164 & 157 & 184\end{array}$

Média

150

Aço de substituição (barra quadrada)

$\begin{array}{lrrrr}\text { CP1 } & 154 & 163 & 170 & 165 \\ \text { CP2 } & 152 & 145 & 147 & 166 \\ \text { CP3 } & 156 & 155 & 152 & 162\end{array}$

Média

157

Os resultados de dureza indicam uma equivalência nesta propriedade entre o SAE 1020 clássico e o aço de substituição, com ligeira vantagem comparativa para este último refletida nos valores médios, 150 e 157 respectivamente.

(v) Ensaios de Impacto Charpy com entalhe em V (resultados em Joules)

SAE 1020 clássico (barra cilíndrica) Aço de substituição (barra quadrada)

$\begin{array}{llll}\text { CP1 } & 142 & \text { CP1 } & 380\end{array}$

$\begin{array}{llll}\text { CP2 } & 126 & \text { CP2 } & 385\end{array}$

$\begin{array}{llll}\text { CP3 } & 140 & \text { CP3 } & 390\end{array}$

$\begin{array}{llll}\text { CP4 } & 130 & \text { CP4 } & 364\end{array}$

$\begin{array}{llll}\text { CP5 } & 112 & \text { CP5 } & 350\end{array}$

$\begin{array}{lll}\text { Média } & 130 & 373\end{array}$ 
Os resultados dos ensaios de impacto indicam valores de tenacidade bem superiores para o aço de substituição, valor médio $130 \mathrm{~J}$ comparativamente ao SAE 1020, valor médio $373 \mathrm{~J}$.

Tenacidade mede a capacidade de um material absorver energia e se deformar plasticamente antes se sofrer fratura. Esse resultado reflete os menores teores de carbono do aço de substituição, à medida que para os aços $\% \mathrm{C} \uparrow \Rightarrow \sigma_{\mathrm{y}} \uparrow$.

A Figura 49 mostra a microestrutura de um aço SAE 1020. Pode-se observar a presença de perlita ao redor de $24 \%$ em peso. A quantidade de perlita é relacionada com a percentagem de carbono em peso no aço (64).

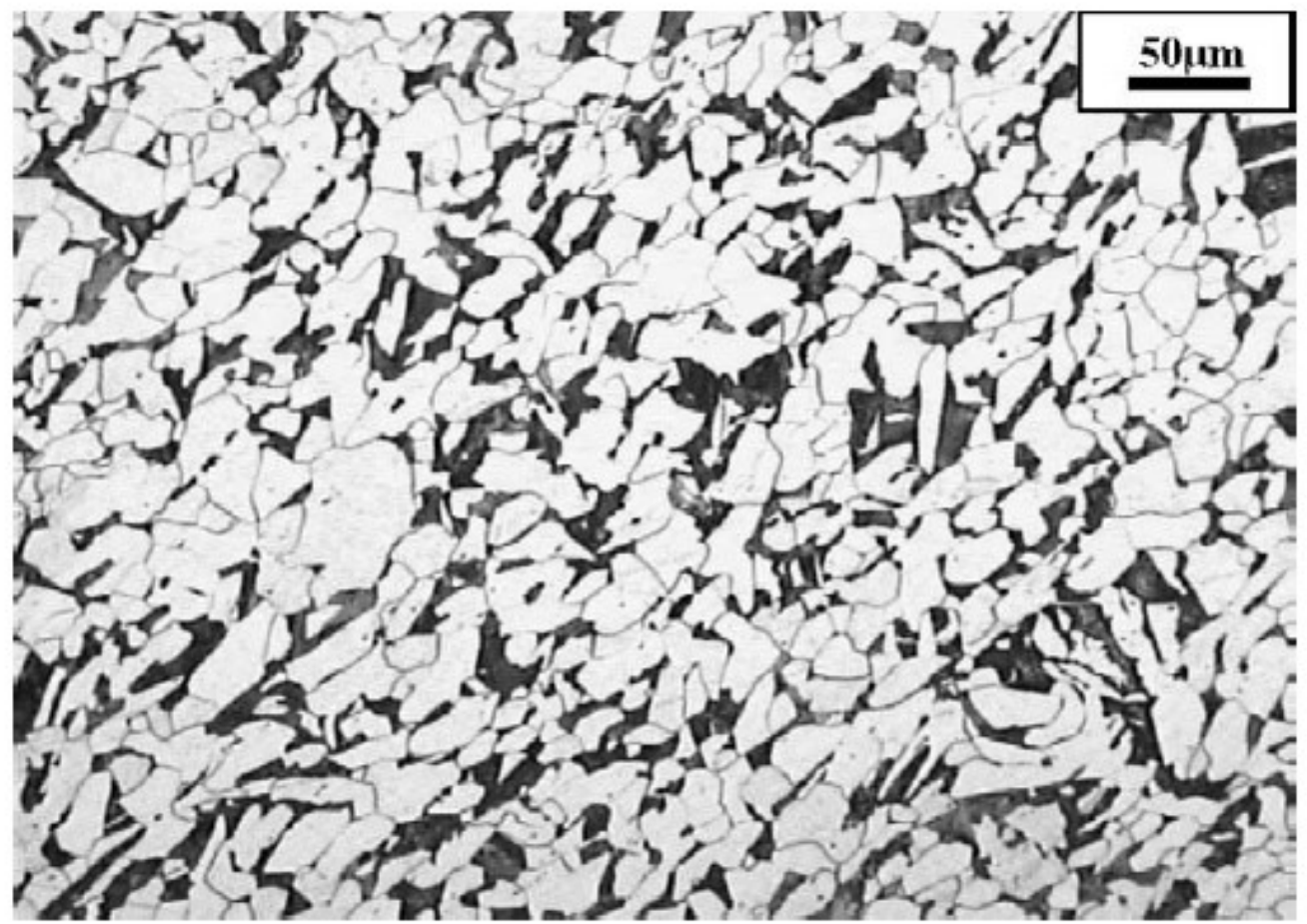

Figura 49 - Microestrutura de aço SAE 1020

Ou seja, à medida que o teor de carbono na amostra do aço de substituição é $65 \%$ do teor deste elemento na amostra do SAE 1020 clássico como indicado na página 56, o aço de substituição apresentará proporcionalmente uma menor formação de perlita do que este.

A dureza e resistência mecânica dos aços comuns ao carbono compostos por ferrita e perlita aumentam com o incremento do teor de carbono. E a tenacidade desses aços decresce à medida que essas duas propriedades aumentam. Teores inferiores de carbono favorecem então a melhoria da tenacidade (65). 
A influência do carbono sobre a tenacidade dos aços pode ser também analisada sob o aspecto da temperatura de transição que define a passagem do comportamento frágil para o dúctil, como mostrado na Figura 50 (66).

O aumento do teor de carbono afeta a energia de impacto e a forma da curva de transição, estendendo a temperatura de transição entre os modos de fratura frágil e dúctil (67).

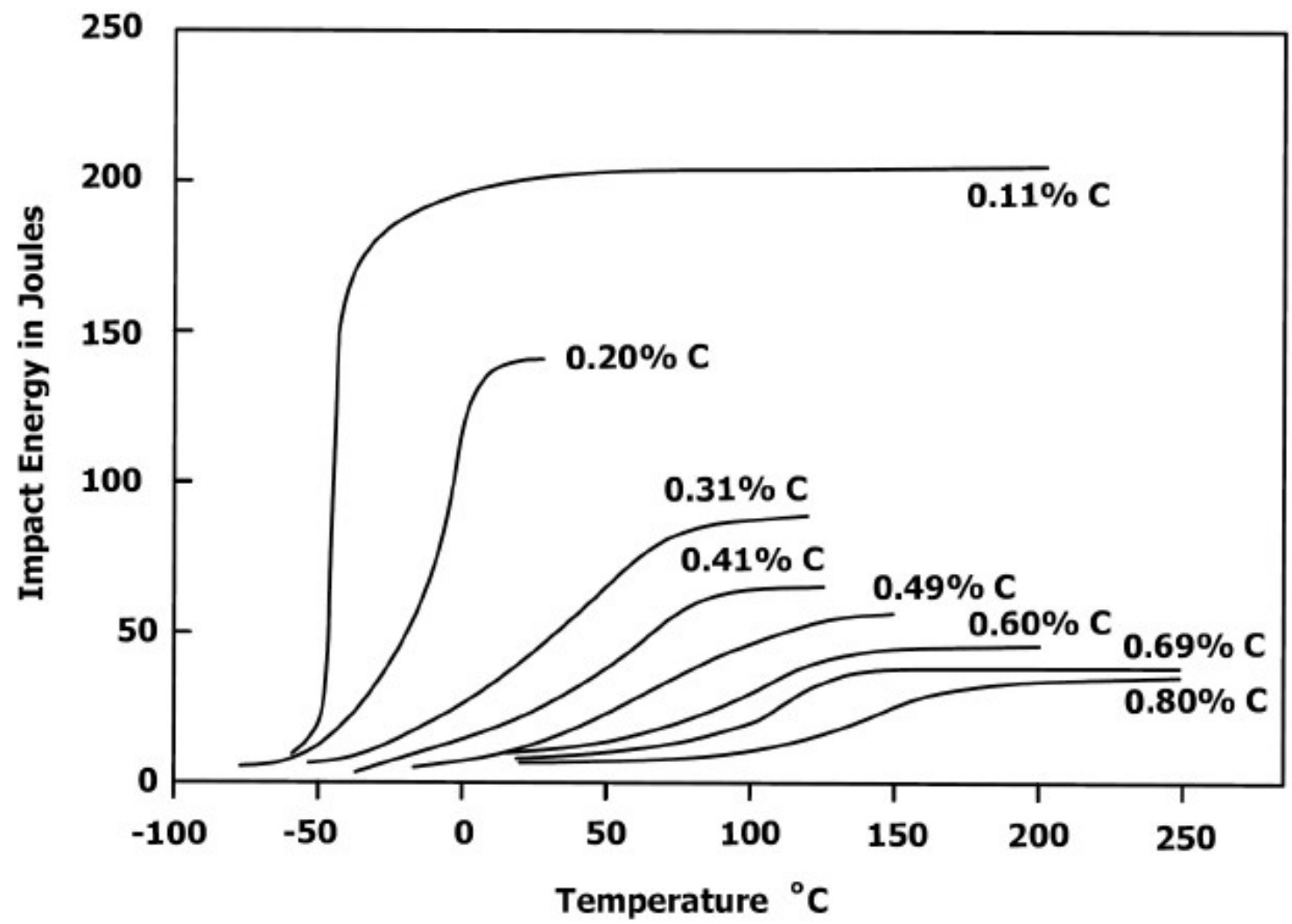

Figura 50 - Energia de impacto versus temperatura em curvas de transiçao dúctil -frágil

O aço de substituição detém um teor de manganês que é quase o dobro do teor deste elemento no SAE 1020 clássico. Cabe então também abordar a influência conjugada do aumento do teor de manganês com a redução concomitante do teor de carbono.

As maiores mudanças da temperatura de transição são resultado de alterações tanto nos teores de carbono quanto nos de manganês. A temperatura de transição reduz-se de $5,5^{\mathrm{O}}$

C para cada incremento de $0,1 \%$ de manganês (68), Figura 51.

As razões para o papel do manganês sobre as propriedades de tenacidade de aços ao carbono e manganês são reportadas como devidas à influência do mesmo no refino de grãos.

A adição de manganês retarda significativamente a formação de ferrita e perlita por mudar a transformação para uma faixa mais baixa de temperatura. 
Uma redução no tamanho médio de grão conduz a uma menor temperatura de transição dúctil- frágil.

Esse fenômeno pode ser entendido sob o aspecto de iniciação e propagação de trincas de clivagem. O tamanho de grão, no caso da ferrita, é um dos fatores mais relevantes sob esse enfoque e o resultado é benéfico para a melhoria das propriedades de tenacidade (69).

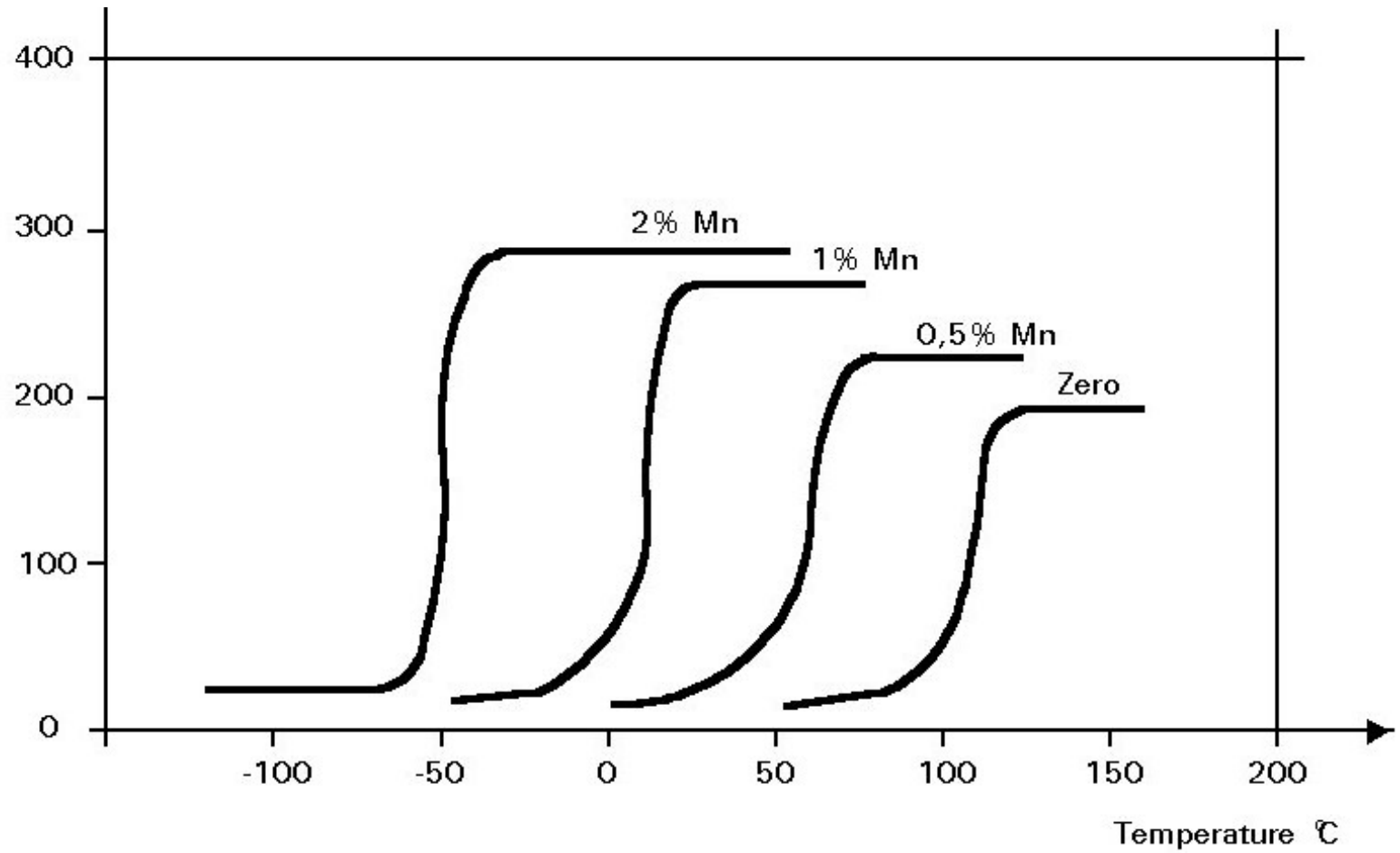

Figura 51 - Efeito do teor de manganês na transição dúctil/frágil em aços $0,05 \%$ $\mathrm{C}(70)$ 


\section{Conclusão e proposição para futuros trabalhos}

A transição do lingotamento convencional para os modernos processos de lingotamento contínuo, na atualidade dominante no setor siderúrgico, trouxe à tona uma série de fenômenos relativos ao comportamento dos aços a elevadas temperaturas antes desconhecidos, fenômenos estes atribuídos ao caráter dinâmico deste processo comparativamente ao convencional, basicamente uma máquina de solidificação.

Entre os fenômenos que afetam a qualidade do material lingotado destaca-se os relativos a transformações peritéticas, as quais provocam uma contração adicional àquela proveniente da contração natural da casca em solidificação no interior do molde.

Essa contração adicional induz a perdas de uniformidade de resfriamento e ao surgimento de fenômenos como o crescimento anormal dos grãos da austenita, o qual afeta o comportamento da ductilidade dos aços a elevadas temperaturas.

A ocorrência de uma série de eventos de qualidade relativos a trincas no material laminado a quente a partir de placas de aço SAE 1020 motivou a criação de uma nova composição química com teores inferiores de carbono em peso e mais elevados teores de manganês que preservasse as propriedades mecânicas requeridas.

Essa nova composição química que resultou em um aço de substituição se demonstrou adequada para solucionar o trincamento a quente.

Ensaios mecânicos realizados em corpos de prova provenientes de amostras de ambos os tipos de aço demonstraram superiores características mecânicas do aço de substituição comparativamente ao SAE 1020 convencional, especialmente de tenacidade.

Esta dissertação propõe oferecer uma visão da fenomenologia associada ao processo de lingotamento contínuo, especialmente aquela relacionado com falhas de qualidade do material lingotado, e todo o embasamento que conduziu à solução de problemas de qualidade dos produtos laminados a quente a partir de placas de aço SAE 1020 e a criação do aço de substituição.

Com base nos resultados obtidos, pode se concluir que a redução do teor de carbono, associada com sua substituição por manganês, promoveu uma melhoria das características mecânicas do material laminado, em especial a tenacidade. Merece destaque que tal substituição preservou as características da resistência mecânica do material laminado a quente, mantendo sua indicação para aplicações estruturais.

Além disto, o aumento do teor em manganês provocou também aumento da razão $\mathrm{Mn} / \mathrm{S}$, o que representa benefícios adicionais às propriedades mecânicas do material, bem como a sua soldabilidade. 
Finalmente, como sugestão para futuros trabalhos correlatos, caberia citar uma pesquisa mais aprofundada sobre a influência das variações dos teores de carbono e manganês sobre as propriedades de tenacidade dos aços, a exemplo da família de graus SAE 41XX que utilizam o cromo e o molibdênio como elementos indutores dos aumentos da resistência mecânica. O SAE 4150, por exemplo, detém um teor de manganês de $0,75 \%$ a $1,00 \%$ em peso.

Sob esse enfoque, caberia analisar a influência de mais elevados teores de manganês sobre as características microestruturais comparativamente a aços com teores inferiores deste elemento. O manganês, como assim reportado, retarda a formação de ferrita e perlita por mudar a transformação para níveis inferiores de temperatura. 


\section{Referências bibliográficas}

1. KURZ, W. About initial solidification in continuous casting of steel. La Metallurgia Italiana, No 7/8, 2008, pp. 56-64.

2. BRIAN, T. Modelling of continuous casting defects related to mold fluid flow. $3^{\text {rd }}$ Congress on Science \& Technology of Steelmaking, AIST, 2005 pp. 874861

3. BRITISH IRON AND STEEL RESEARCH ASSOCIATION - Continuous Casting Defects Group. Definitions and causes of continuous casting defects. ISI Book 106, 1967

4. NORMANTON, A. S., et al. Improving surface quality of continuously cast semis by an understanding of shell development and growth. European Commission - Technical Steel Research - Casting, reheating and direct rolling Final Report, 2000 - 2003

5. MAZUMDAR, S.; RAY S.K. Solidification control in continuous casting of steel. Sadhana, Vol. 26, Parts 1 \&2, February - April 2001, pp. 178 - 198.

6. BRIAN, T. Internal Crack Formation in CC steel slabs. University of Illinois, 2007.

7. SIYASIYA, C., et al. Metallurgical factors that affect the strand width during continuous casting of DIN 1.40003 stainless steel. The Journal of The South African Institute of Mining and Metallurgy Volume 105, 2005.

8. LAMANT, J.Y., et al, Study of the bulging of continuously casting slabs. European Commission - Technical Steel Research IRSID - Final Report, 1985.

9. CRAMB, W. Elimination or minimization of oscillation marks - A path to improve surface quality. Carnegie Mellon University - Department of Materials Science and Engineering, 2008.

10. SENGUPTA, J.; BRIAN, T. Visualization of hook and oscillation mark formation mechanism in ultra-low carbon steel slabs during continuous casting. Journal of Metals, 2006.

11. HARADA S., et al, A Formation Mechanism of Transverse Cracks on CC Slab Surface. ISIJ International, Vol. 30 (1990), No. 4, pp. 310-316.

12. MIMURA Y. Sticking-type breakouts during the continuous casting of steel slabs. The University of Tokyo, 1979.

13. LE PAPILLON, Y., et al, Determination of High Temperature Surface Crack Formation Criteria in Continuous Casting. European Commission - Technical Steel Research - Casting and Solidification - Final Report, 2002.

14. BERNHARD, C., et al, "The Working Group "Continuous Casting and Materials". AIS Tech 2010 Proceedings - Volume II. 
15. ASM INTERNATIONAL, Phase diagrams - understanding the basics peritetic alloy systems, 2012.

16. CIÊNCIA DOS MATERIAIS MULTIMÍDIA, Capítulo 8.15 O diagrama peritético. Disponível em http://www.cienciadosmateriais.org/index.php?acao=info, acessado em agosto de 2016.

17. KALINUSHKIN, E. Steels of peritetic type: peculiarities of structure, alloying technology and use. Metalurgija 41 (2002) 3, pp. 131-138.

18. ASM Handbook, Vol.9, Metallography and Microstructures, 2004, p.100

19. HULKA, K.; GRAY, J.M. High temperature processing of line-pipe steels. Pipeline Technology Volume II, 2000. Não paginado.

20. FUJDA M. Centerline segregation of continuously cast slabs - Influence on microstructure and fracture morphology. Journal of Metals, Materials and Minerals Vol. $15 \mathrm{~N}^{\mathrm{o}}$ 2, pp. 45-51, 2005.

21. GHOSH, A. Segregation in cast products. Sadhana, Vol.26, Parts 1 \& 2, pp 5-14, 2001.

22. SHIP STRUCTURE COMMITTEE - US COAST GUARD. Carbon equivalence and weldability of microalloyed steels, 1991.

23. SCHREWE, H. Continuous casting of steel - Fundamentals principles and practice. Sthal und Eisen, p. 1, 1987.

24. OKUMURA, H. Recent trends and future prospects of continuous casting technology. Nippon Steel Technical Report No. 61, 1994.

25. THOMAS, B., et al, The Formation of Panel Cracks in Steel Ingots: A Stateof-the Art Review. ISS Transactions, Volume 7, 1986.

26. HARADA, S., et al, A Formation Mechanism of Transverse Cracks on CC Slab Surface. ISIJ International, Vol. 30, No. 4, pp. 310-316, 1990.

27. OLIVEIRA, L., et al, Metodologia Experimental para Avaliação da Contração dos Aços Peritéticos em Diferentes Condições de Extração de Calor. Tecnol. Metal. Mater. Miner., São Paulo, v7, n. 1-2, p.36, 2010.

28. REITER, J., et al, Austenite grain size in the continuous casting process: Metallographic methods and evaluation. Elsevier, 2007.

29. DIPPENAAR, R., et al, Austenite grain growth and the surface quality of continuously cast steel. Metallurgical and Materials Transactions B: Processing Science, 45(2), pp. 409-418, 2014. 
30. XU, K.; THOMAS, B. Prediction of Grain Size, Precipitation and Crack Susceptibility in Continuous Casting. AISI Tech 2009 Steelmaking Conference Proc., 2009.

31. NAGASAKI, C., et al, Influence of Manganese and Sulfur on Hot Ductility of Carbon Steels at High Strain Rate. Department of Metallurgy, Faculty of Engineering; The University of Tokyo, 1987.

32.CARPENTER, K., et al, Influence of isothermal treatment on MnS and hot ductility in low carbon, low Mn steels. Metallurgical and Materials Transactions B: Process Metallurgy and Materials Processing Science, 45 (2), pp. 372-380, 2014.

33. SUZUKI, M., et al, Recovery of Hot Ductility by Improving Thermal Pattern of Continuously Cast Low Carbon and Ultra Low Carbon Steels Slabs for Hot Direct Rolling. Institute for Advanced Materials Processing, Tohoku University, 1997.

34. MINERAL SOCIETY OF AMERICA. Disponível em http://www.minsocam.org/MSA/collectors_corner/arc/scn1.htm, acessado em agosto 2016

35.BRANDALEZE, E., et al, Mold Fluxes in the Steel Continuous Casting Process. INTECH, 2012.

36. LI, Y., et al, Control of Mold Level Fluctuation through the Modification of Steel Composition. International Journal of Minerals, Metallurgy and Materials, Vol. 20, p. 138, 2013.

37. PAVLISKA, J., et al, Some Microstructural Aspects of Transverse Crack Formation in Continuously Cast Steel. Technical University Ostrava, Institute of Materials Engineering. Não paginado e datado.

38. SIYASIYA, C., et al, Metallurgical Factors that Affect the Strand Width during Continuous Casting of DIN 1.4003 Stainless Steel. Transaction paper Department of Materials Science and Metallurgical Engineering of the University of Pretoria, p. 474 maio 2005.

39. FU, J-X.; HWANG W-S. Numerical Simulation of Slab Broadening in Continuous casting of steel. INTECH, p. 559 p. 569, 2012.

40. DREZET, J.-M., et al, A new hot tearing criterion for steel. $4^{\text {th }}$ ECCC, 2002. Não paginado.

41. MILANI, C. Relatório de visita à CIPALAM Indústria e Comércio de Laminados Ltda., jun. 2013.

42. MILANI, C. Registros de visitas à CIAFAL - Comércio e Indústria de Artefatos de Ferro e Aço para análise e discussão sobre problemas de qualidade relacionados ao processamento de placas de aços SAE 1020, avalição dos 
resultados obtidos com o aço de substituição e comunicações internas trocadas a respeito, $2013-2014$.

43. MILANI, C. An overview on the Brazilian carbon steel flat production structure. Production structure, market and prospects for TKCSA, abril 2013.

44. MILANI, C. Registros de visitas à MONTEPINO Ltda. para análise e discussão sobre problemas de qualidade relacionados ao processamento de placas de aços SAE 1020, 2014.

45. NBR 7007 Aço - carbono e microligados para barras e perfis laminados a quente para uso estrutural, segunda edição 19.08.2011.

46. TIMKEN Practical Data for Metallurgists. 17ª edição, p. 4, 2011.

47. THE MAKING, SHAPING AND TREATMENT OF STEEL - Chapter 39 Merchant - Bar Production. United States Steel, Ninth Edition, 1970.

48. MILANI, C. Registros de visitas à CIPALAM Indústria e Comércio de Laminados Ltda., para análise e discussão sobre problemas de qualidade relacionados ao processamento de placas de aços SAE 1020 e acompanhamento de testes de desempenho do aço de substituição, 2013 - 2014.

49. MILANI, C. Arquivos pessoais. Imagens tornadas públicas. Não datado.

50. NAKASHIMA, J.; TOH, T. Improvement of Continuously Cast Slabs by Decreasing Nonmetallic Inclusions. Nippon Steel Technical Report No. 104, 2013.

51. UESHIMA, Y., et al, Hydrogen-induced Sticker Breakouts in Continuous Casting of Steel. Nippon Steel Corporation, Technical Development Bureau. Não datado.

52. TERNIUM. Technical Protocol - Slabs to Ternium Mexico, p.9, 2013.

53. WHITE, C.V., et al, Solidification Structure and the Effects of Hot Reduction in Continuously Cast Steels for Bars and Forgings, p.75, 1998.

54. PE'LAK, S., et al, Between the Dendrite Structure Quality, the Casting Technology and the Defects in Continuously Cast Slabs. Materials Engineering, Vol.16, No.4, p.22, 2009.

55. JIAN, C., et al, Progress of Production Technology of Clean Steel in Baosteel. Baoshan Iron and Steel Co., LTD. Não datado.

56. MONTEPINO LTDA. Relatório Técnico, 2013.

57. WOOD, W. U.S. Department of Transportation. Heat - Affected Zone Studies of Thermally Cut Structural Steels, 1994. 
58. BAIN, EDGARD C. Functions of the Alloying Elements in Steel. American Society for Metals, 1939

59. INDUSTRIAL HEATING. Disponível em http://www.industrialheating.com/, acessado em agosto 2016.

60. ADAMCZYK, J. Development of the microalloyed constructional steels. Journal of Achievements in Materials and Manufacturing Engineering, V.14, 2006.

61. RAWDON, H.; SILLERS, F. Preparation and Properties of Pure Iron Alloys: III. Effect of Manganese on the Iron-Carbon System. US Department of Commerce, 1922.

62. CIPALAM. Protocolo Técnico para Fornecimento de Placas, junho 2013.

63. CIAFAL. Especificação Técnica Rev.5, janeiro 2014.

64. MACHADO, I. Technological advances in steels heat treatment. Journal of Materials Processing Technology, February 2006. Não paginado.

65. ASM Metals Handbook Volume 4 - Heat Treatment, 1991.

66. JOHNSON, A.; STOREY, R. The Effect on The Charpy V-Notch Ductile Brittle Transition Curve. Não datado.

67. SURIAN, E., et al, Influence of Carbon on Mechanical Properties and Microstructure of Weld Metal from a High-Strength SMA Electrode. Carbon ranges are determined for optimum toughness properties. SUPPLEMENT TO THE WELDING JOURNAL, June 19914.

68. CIMM - Centro de Informação Metal Mecânica. Disponível em: http://www.cimm.com.br/portal/material didatico/6581\#.WFVYZPkrLIU. Acessado em dezembro de 2016.

69. SONG, R., et al, Influence of Mn Content on the Microstructure and Mechanical Properties of Ultrafine Grained C-Mn Steels. ISIJ International, January 2005.

70. Applied Metallurgy. Disponível em: http://fgg-web.fgg.uni-lj.si/ /pmoze/esdep/master/wg02/toc.htm Acessado em dezembro de 2016. 